\title{
Wind Energy Resource Assessment of The Caribbean and Central America
}

\author{
DL Elliott \\ CG Holladay \\ CI Aspliden \\ MN Schwartz \\ GL Gowerl
}

April 1987

Prepared for the U.S. Department of Energy under Contract DE-AC06-76RL01830 


\title{
DISCLAIMER
}

This report was prepared as an account of work sponsored by an agency of the United States Government. Neither the United States Government nor any agency thereof, nor Battelle Memorial Institute, nor any of their employees, makes any warranty, express or implied, or assumes any legal liability or responsibility for the accuracy, completeness, or usefulness of any information, apparatus, product, or process disclosed, or represents that its use would not infringe privately owned rights. Reference herein to any specific commercial product, process, or service by trade name, trademark, manufacturer, or otherwise does not necessarily constitute or imply its endorsement, recommendation, or favoring by the United States Government or any agency thereof, or Battelle Memorial Institute. The views and opinions of authors expressed herein do not necessarily state or reflect those of the United States Government or any agency thereof.

\author{
PACIFIC NORTHWEST NATIONAL LABORATORY \\ operated by \\ BATTELLE \\ for the \\ UNITED STATES DEPARTMENT OF ENERGY
}

under Contract DE-AC06-76RL01830

Printed in the United States of America

Available to DOE and DOE contractors from the

Office of Scientific and Technical Information,

P.O. Box 62, Oak Ridge, TN 37831-0062;

ph: (865) 576-8401

fax: (865) 576-5728

email: reports@adonis.osti.gov

\begin{abstract}
Available to the public from the National Technical Information Service, U.S. Department of Commerce, 5285 Port Royal Rd., Springfield, VA 22161 ph: (800) 553-6847 fax: (703) 605-6900

email: orders@ntis.fedworld.gov

online ordering: http://www.ntis.gov/ordering.htm
\end{abstract}

This document was printed on recycled paper.

$(8 / 00)$ 

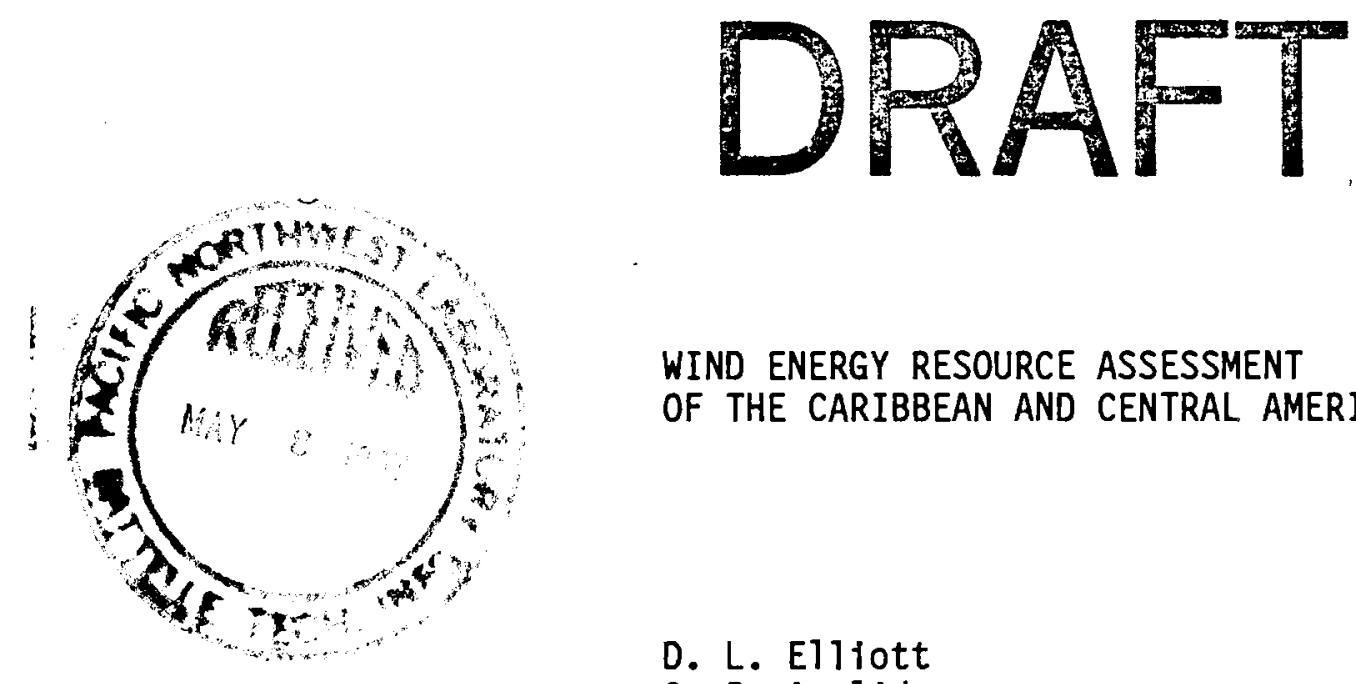

PNL- $\underset{U C-60}{2} 34$

WIND ENERGY RESOURCE ASSESSMENT

OF THE CARIBBEAN AND CENTRAL AMERICA

D. L. Elliott

C. I. Aspliden

G. L. Gower

C. G. Hoiladay

M. N. Schwartz

Apri 1987

Prepared for

the U.S. Department of Energy

under Contract DE-AC06-76RLO 1830

Pacific Northwest Laboratory

Richland, Washington 99352 
$\checkmark$ 


\section{SUMMARY}

A wind energy resource assessment of the Caribbean and Central America has identified many areas with good to outstanding wind resource potential for wind turbine applications. Annual average wind resource maps and summary tables have been developed for 35 island/country areas throughout the Caribbean and Central America region. The wind resource maps highlight the locations of major resource areas and provide estimates of the wind energy resource potential for typical we11-exposed sites in these areas. The average energy in the wind flowing in the layer near the ground is expressed as a wind power class: the greater the average wind energy, the higher the wind power class. The summary tables that are included with each of the 35 island/country wind energy maps provide information on the frequency distribution of the wind speeds (expressed as estimates of the Weibull shape factor, k) and seasonal variations in the wind resource for the major wind resource areas identified on the maps. A new wind power class legend has been developed for relating the wind power classes to values of mean wind power density, mean wind speed, and Weibull k. Guidelines are presented on how to adjust these values to various heights above ground for different roughness and terrain characteristics.

Information evaluated in preparing the assessment included existing meteorological data from airports and other weather stations, and from ships and buoys in offshore and coastal areas. In addition, new data from recent measurement sites established for wind energy siting studies were obtained for a few areas of the Caribbean. Other types of information evaluated in the assessment were climatological data and maps on winds aloft, surface pressure, air flow, and topography. The various data were screened and evaluated for their usefulness in preparing the wind resource assessment. Much of the surface data from airports and other land-based weather stations were determined to be from sheltered sites and were thus not very useful in assessing the wind resource at locations that are well exposed to the winds. Ship data were determined to be the most useful for estimating the large-scale wind flow and assessing the spatial distribution of the wind resource throughout the region. Techniques were developed for analyzing and correcting ship 
wind data and extrapolating these data to coastal and inland areas by considering terrain influences on the large-scale wind flow. In areas where extrapolation of ship wind data was not entirely feasible, such as interior areas of Central America, other techniques were developed for estimating the wind flow and distribution of the wind resource.

Through the application of the various innovative techniques developed for assessing the wind resource throughout the Caribbean and Central America region, many areas with potentially good to outstanding wind resource were identified that had not been previously recognized. In areas where existing site data were available from exposed locations, the measured wind resource was compared with the estimated wind resource that was derived using the assessment techniques. In most cases, there was good agreement between the measured wind resource and the estimated wind resource.

This assessment project supported activities being pursued by the U.S. Committee for Renewable Energy Commerce and Trade (CORECT), the U.S. government's interagency program to assist in overseas marketing and promote renewable energy exports. An overall goal of the program is to improve U.S. competitiveness in the world renewable energy market. The Caribbean and Central America assessment, which is the first of several possible follow-on international wind energy resource assessments, provides valuable information needed by the U.S. wind energy industry to identify suitable wind resource areas and concentrate their efforts on these areas. 


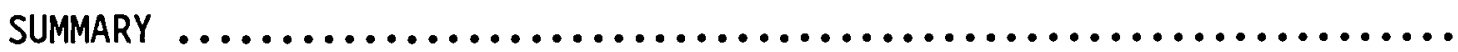

INTRODUCTION $\ldots \ldots \ldots \ldots \ldots \ldots \ldots \ldots \ldots \ldots \ldots \ldots \ldots \ldots \ldots \ldots \ldots \ldots \ldots \ldots \ldots$

ASSESSMENT METHODOLOGY ............................... 5

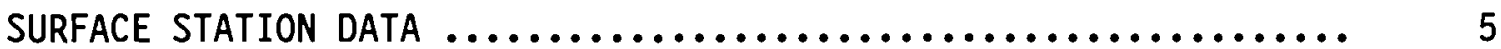

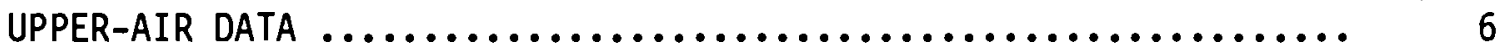

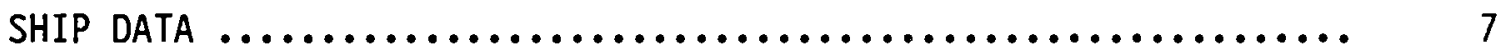

PREVAILING DIRECTIONS OF POWER-PRODUCING WINDS $\ldots \ldots \ldots \ldots \ldots \ldots \ldots$

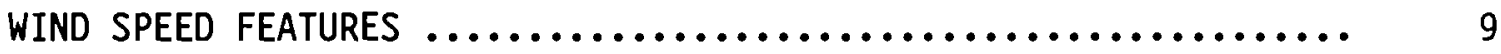

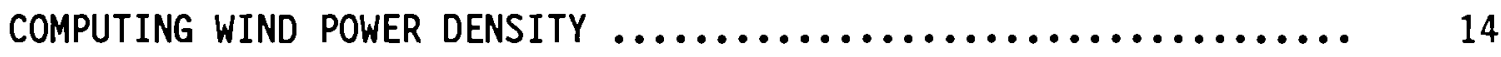

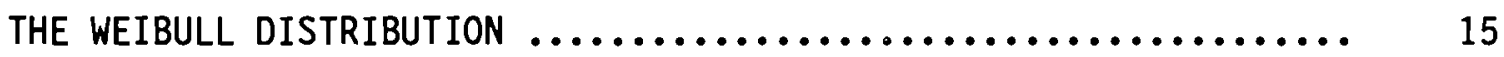

WEIBULL $k$ FEATURES $\ldots \ldots \ldots \ldots \ldots \ldots \ldots \ldots \ldots \ldots \ldots \ldots \ldots \ldots \ldots \ldots$

WIND ENERGY FEATURES $\ldots \ldots \ldots \ldots \ldots \ldots \ldots \ldots \ldots \ldots \ldots \ldots \ldots \ldots \ldots \ldots \ldots \ldots \ldots$

METHODS FOR CORRECTING AND EXTRAPOLATING SHIP DATA ........... 20

IDENTIFYING USEFUL DATA SETS FOR COMPARISON $\ldots \ldots \ldots \ldots \ldots \ldots \ldots \ldots . . \ldots \ldots$

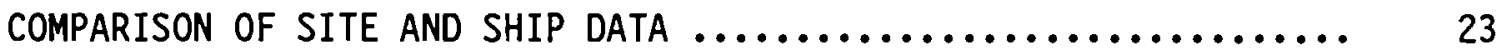

EXTRAPOLATING SHIP DATA TO COASTAL AND INLAND AREAS ........... 24

FLAT TERRAIN INFLUENCES ON THE FLOW .................... 25

SMALL-SCALE TERRAIN INFLUENCES ON THE FLOW ............... 26

LARGE-SCALE TERRAIN INFLUENCES ON THE FLOW ................ 27

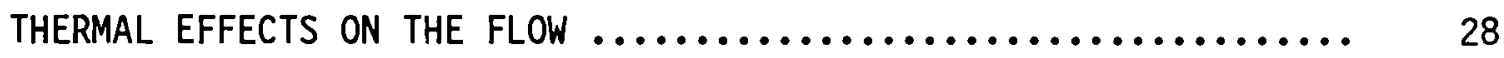

ESTIMATING THE WIND FLOW IN CENTRAL AMERICA ............... 29

ANALYSIS OF THE PRESSURE GRADIENTS IN CENTRAL AMERICA ........ 30

THE WIND ENERGY RESOURCE MAPS ......................... 33

USING AND INTERPRETING THE ISLAND/COUNTRY WIND RESOURCE MAPS .... 33

USING AND INTERPRETING THE ISLAND/COUNTRY WIND RESOURCE TABLES .. 37

ESTIMATING MEAN WIND SPEEDS AND EXTRAPOLATING TO DIFFERENT

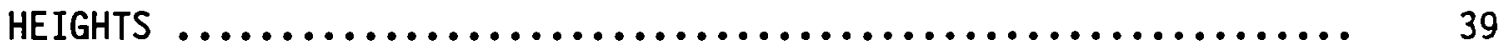

ESTIMATING PREVAILING DIRECTIONS OF THE POWER-PRODUCING WINDS ... 39

ISLAND/COUNTRY MAPS AND TABLES ..................... 41

Grenada .................................. 42

Saint Vicent and the Grenadines .................... 44

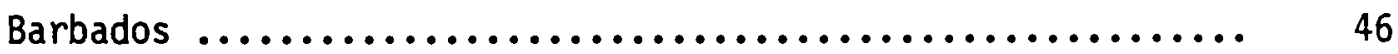

Saint Lucia $\ldots \ldots \ldots \ldots \ldots \ldots \ldots \ldots \ldots \ldots \ldots \ldots \ldots \ldots \ldots \ldots . \ldots \ldots \ldots$ 


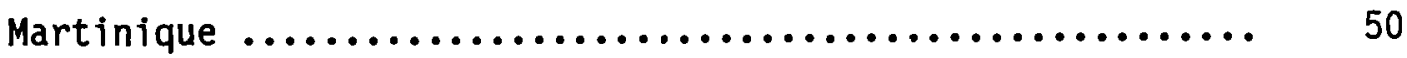

Dominica .................................... 52

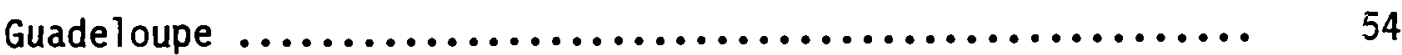

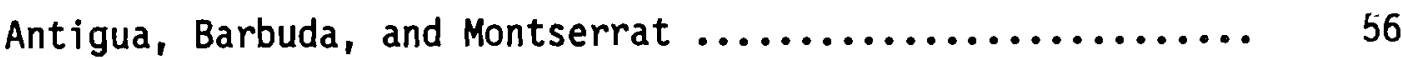

Nevis, Saba, Saint Christopher, Sint Eustatius ........... 58

Anguilla, Saint Martin, and Saint Barthelemy ............. 60

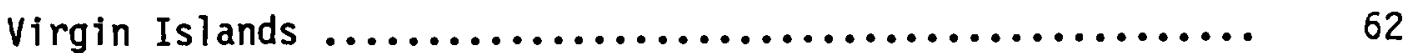

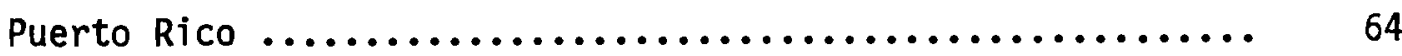

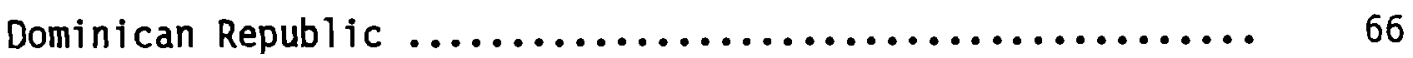

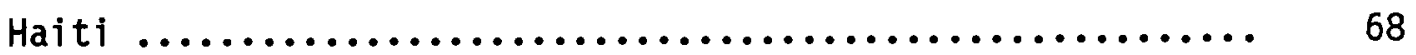

Jamaica .................................... 70

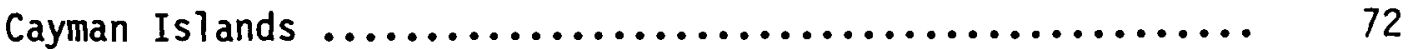

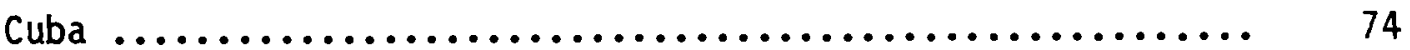

Bahamas - Grand Bahama and Great Abaco Islands .......... 76

Bahamas - Andros, Berry, and New Providence ............ 78

Bahamas - Cat, Eleuthera, and Great Exuma Islands ......... 80

Bahamas - Acklins, Crooked, Long, and San Salvador Islands . 82

Bahamas - Inagua and Mayaguana Islands ................ 84

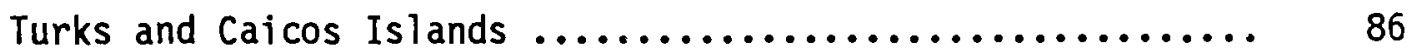

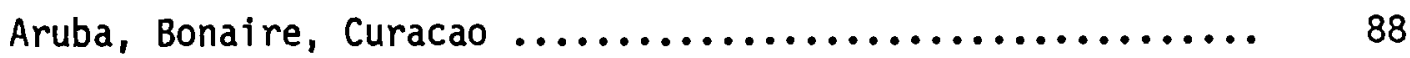

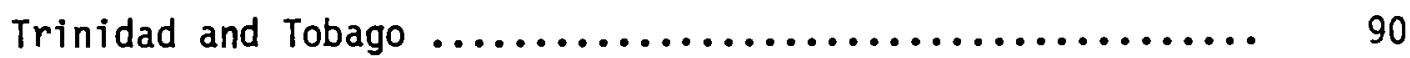

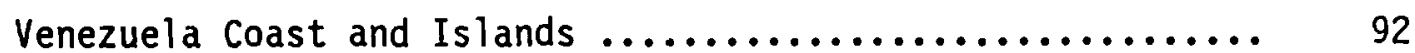

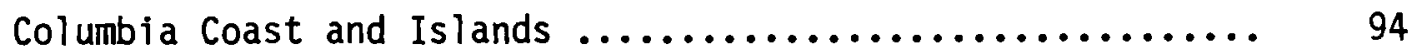

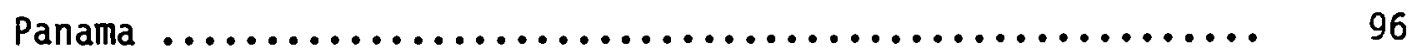

Costa Rica ................................... 98

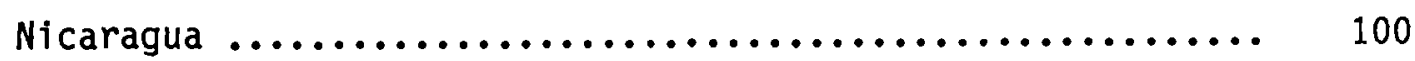

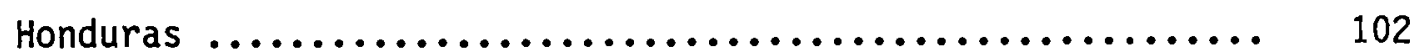

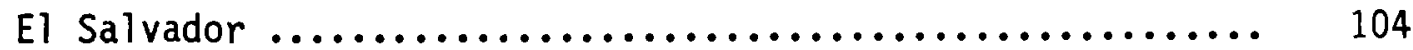

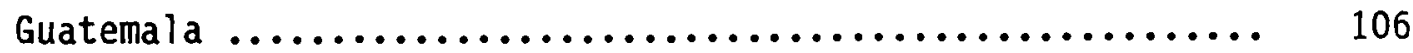

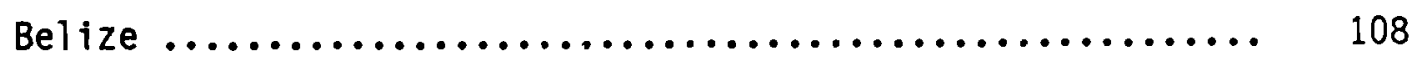

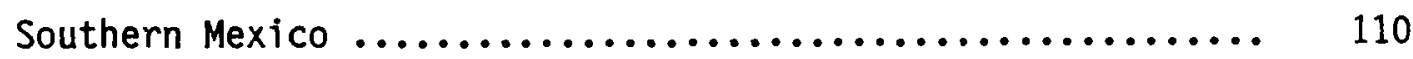

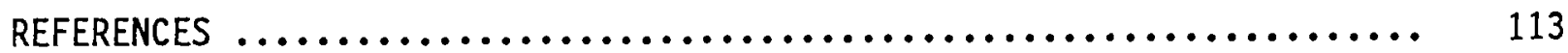

APPENDIX: MONTHLY MAPS OF THE PREVAILING DIRECTIONS OF POWER-

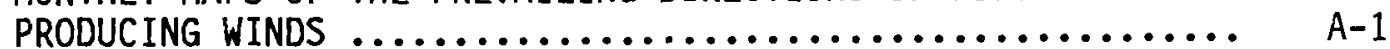




\section{FIGURES}

$1 \quad$ Previous Caribbean Wind Energy Resource Assessment (From the 1981 World-Wide Resource Assessment by PNL)

2 Ship Wind Observations in the Caribbean Region Period of Record - Late 1800 s to 1970 ................... 8

3 January: Prevailing Direction of Power-Producing Winds ..... 10

4 July: Prevailing Direction of Power-Producing Winds ........

$5 \quad$ Annual Average Wind Speeds for One-Degree Quadrangle Marine Areas, Computed from Ship Wind Observations ................

6 Annual Average Wind Speeds $(\mathrm{m} / \mathrm{s})$ for Marine Areas of the Caribbean, Derived from an Analys is of the One-Degree Quadrangle Ship Data ..............................

$7 \quad$ Wind Speed Frequency Distributions for Various Weibull k Values and a Mean Wind Speed of $5.4 \mathrm{~m} / \mathrm{s}(12 \mathrm{mph}) . . . \ldots \ldots \ldots$

8 Annual Average Weibull k Values for Marine Areas of the Caribbean, Derived from an Analysis of the One-Degree

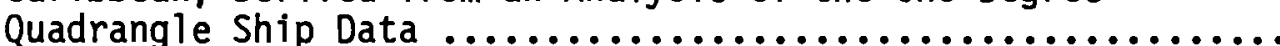

9 Annual Average Wind Power Classes for Marine Areas of the Caribbean, Derived from an Analysis of the One-Degree

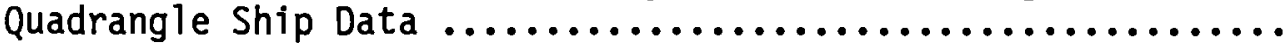

10 January Mean Sea-level Pressures (mb), Derived from an Analysis of the One-Degree Quadrangle Ship Data ............

11 Wind Power Class Legend for Relating Values of Mean Wind Power Density $\left(\mathrm{W} / \mathrm{m}^{2}\right)$, Weibull $k$ and Mean Wind Speed $(\mathrm{m} / \mathrm{s}) \ldots$ 


\section{$\underline{\text { TABLES }}$}

$1 \quad$ Classes of Wind Power Density at $10 \mathrm{~m} \ldots \ldots \ldots \ldots \ldots \ldots \ldots \ldots$

2 Corrected Weibull k Values for Various Weibull $k_{s}$ Values .... 24

$3 \quad$ Listing and Arrangement of the 35 Island/County Wind Energy Resource Maps for the Caribbean and Central America Region ..

4 Weibull k Multiplication Factors for Adjusting Weibull k Values at $10 \mathrm{~m}$ Over Open Ocean to Flat Coastal and Inland

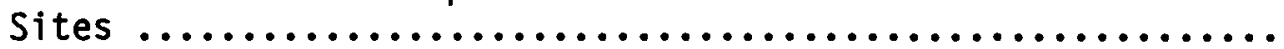

5 Wind Speed Multiplication Factors for Extrapolating Mean Wind Speeds at $10 \mathrm{~m}$ to Other Heights Over Flat Terrain ........... 


\section{$\underline{\text { INTRODUCTION }}$}

In 1981 a world-wide wind energy resource assessment and map were prepared by the Pacific Northwest Laboratory (Cherry et al. 1981). The assessment was made using previous assessments and methods developed at that time to analyze available wind data in order to estimate the broad-scale distribution of the wind energy resource over the world. The world-wide assessment map is useful for identifying relatively broad-scale features of the wind resource, although smaller-scale resource areas such as wind corridors can be identified in some areas where existing data were available. However, in most regions of the world, considerably greater spatial variability exists than is shown on the world-wide map, and in some areas the wind resource estimates may be incorrect because of inaccuracies or limitations in the data base that was used and the techniques that were applied in extrapolating these data. In many regions of the world, more detailed and accurate assessments could be produced, because considerably more data exist than were used in the world-wide assessment and more sophisticated techniques have been developed that can be applied in such regional or local area assessments. Moreover, the world-wide assessment map does not provide information on the seasonal variability of the wind resource nor does it provide information on the frequency distribution of wind speeds, both of which are important in initial wind resource assessment feasibility studies.

The primary purpose of this assessment study was to produce a more comprehensive, updated wind energy resource assessment for the Caribbean and Central America region for use in identifying potentially suitable areas for wind turbine applications. (The previous assessment, shown in Figure 1, was extracted from the 1981 world-wide assessment.) This updated assessment was completed using only existing data that could be readily identified and obtained. Existing methodologies used in previous wind resource assessments, such as the United States assessments (Elliott et al. 1987, Pacific Northwest Laboratory 1980-1981), were evaluated for their applicability and usefulness in updating the wind resource estimates for the Caribbean and Central America.

New and refined techniques were developed and tested, as were appropriate, to 
more accurately estimate the wind energy resource distribution throughout the Caribbean and Central America region. 


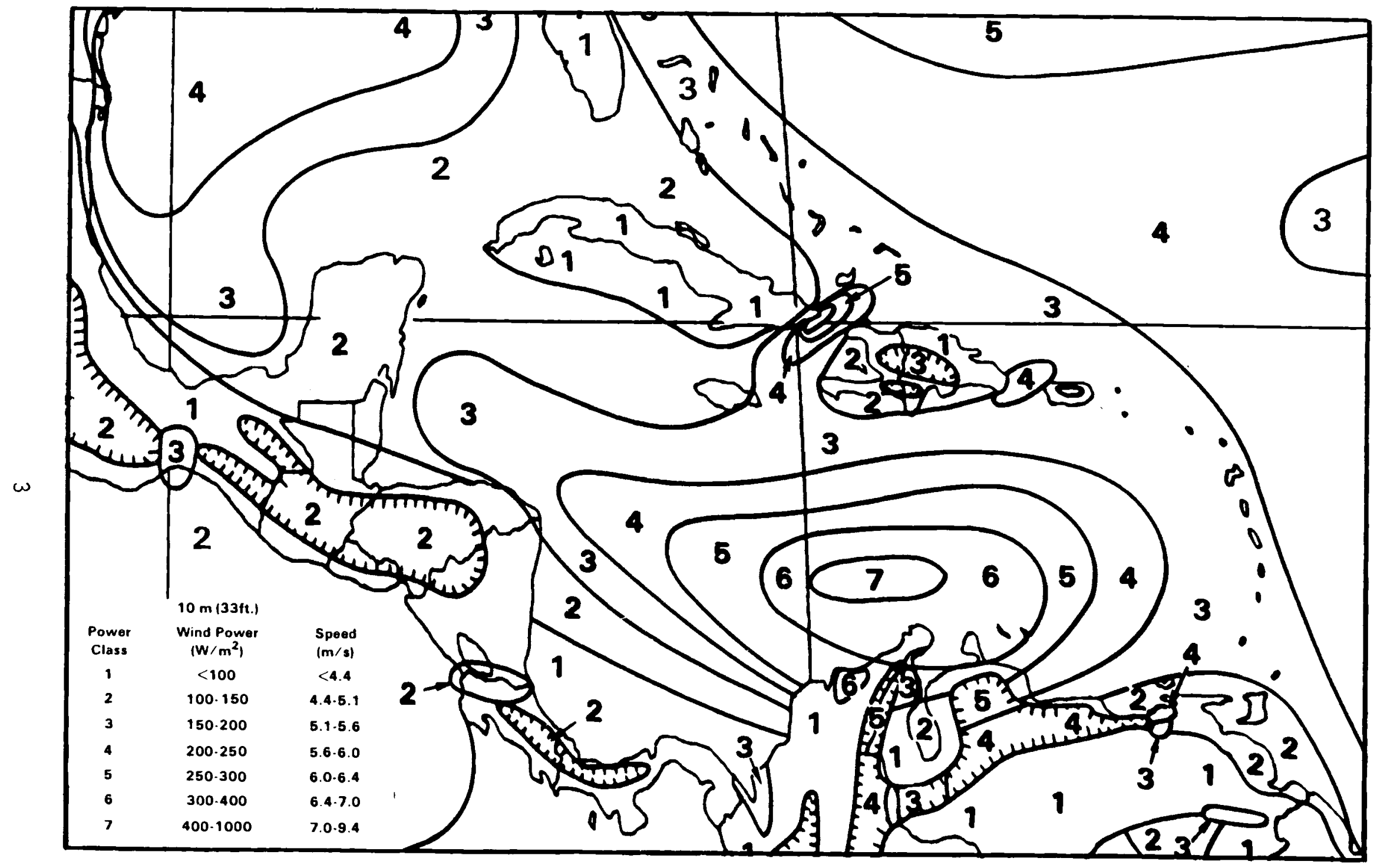

FIGURE 1. Previous Caribbean Wind Energy Resource Assessment

(From the 1981 World-Wide Resource Assessment by PNL) 



\section{ASSESSMENT METHODOLOGY}

\section{DATA SOURCES}

Various organizations were contacted to identify data sources, wind energy studies, and other materials for potential use in preparing the assessment. These organizations included the U.S. National Climatic Data Center (NCDC), the Caribbean Meteorological Institute (CMI), the Caribbean Development Bank (CDB), the U.S. Agency for International Development (AID) Caribbean Regional Development Office, Transenergy Consultants Limited (based in Barbados), the Latin America Energy Organization (OLADE), the Alternative Energy Institute (AEI), Volunteers in Technical Assistance (VITA), Research Triangle Institute (RTI), Meridian Corporation, Center for Energy and Environment Research (CEER), and various national meteorological services and energy offices. Books, such as the World Survey of Climatology (Bryon and Hare 1983, Schwerdtfeger 1976, and Van Loon 1984), atlases, such as the U.S. Navy and other marine climatic at lases (Naval Oceanography Command 1981 and 1985-1986, Naval Oceanography and Meteorology 1977, Naval Weather Service Command 1974, and Isemer and Hasse 1985), and climatological reports were reviewed for useful data and information on the regional wind characteristics and flow features.

Several different types of historical meteorological data were identified and evaluated for their potential use in assessing the wind resource throughout the region. These included surface wind data from airfields and other weatherreporting stations, upper-air data, and ship data from offshore marine areas. New data from recent wind measurement sites established for wind energy siting studies were obtained for a few areas of the region, such as some of the Eastern Caribbean Islands (Caribbean Development Bank 1984), Puerto Rico, Honduras, and Jamaica.

\section{SURFACE STATION DATA}

Fortunately, much of the historical surface wind data from airfields and weather-reporting stations have been previously summarized and, thus, annual and seasonal or monthly mean wind speeds can be obtained without acquiring and processing the hourly data. For many of the stations that have historical 
wind data, mean wind power densities have also been computed. The available summaries of these surface wind data were assimilated from the various sources and then screened and evaluated for their usefulness in preparing a comprehensive regional assessment. Considerably more historical data were identified and obtained for the region than had been used for the region in the worldwide wind resource assessment. However, unfortunately, most of the historical data are from sheltered sites and are thus not very useful or reliable in assessing the wind resource at locations that are well exposed to the winds.

\section{UPPER-AIR DATA}

Upper-air wind data can be useful in establishing vertical profiles of wind speed for extrapolation of the wind energy resource to elevated terrain features. For this assessment, summaries of the mean upper-air wind speeds and directions at heights intervals of $300 \mathrm{~m}$ to $500 \mathrm{~m}$ up to heights of $2500 \mathrm{~m}$ would be desirable for the Caribbean and Central America region. However, existing upper-air summaries, which were obtained for 10 stations throughout the region, only provided information on winds at heights of approximately $1500 \mathrm{~m}, 3000 \mathrm{~m}$, and higher (except for San Juan, Puerto Rico which had been previously summarized in greater detail (Wegley et al. 1981)). These heights correspond to standard pressure levels commonly used in upper-air weather analysis charts, such as $850 \mathrm{mb}, 700 \mathrm{mb}, 500 \mathrm{mb}$, etc. Thus, existing upper-air summaries were of very limited use in establishing vertical profiles of wind speed and direction in the lower atmospheric boundary layer which is of importance in wind energy assessment. We used the upper-air summaries mainly to obtain a rough estimate, or indication, of the depth of the trade-wind layer.

Raw unsummarized upper-air data are available on magnetic tape from the U.S. National Climatic Data Center for about 20 stations in the region. The usefulness of performing a detailed analysis of the raw unsummarized upperair data to improve the overall accuracy and certainty of the wind resource estimates is unknown and depends to a large extent on the reliability and representativeness of the station data for characterizing the large-scale ambient wind flow. (For example, local terrain influences on the wind profiles, observation times and completeness, number of levels and heights of 
the observations, and length of record are some of the criteria which need to be considered in evaluating the reliability and representativeness of the upper-air data.) Because the raw upper-air data must be processed before they can be screened and evaluated for their potential usefulness in the wind energy assessment, an analysis of the raw upper-air data was not performed as we considered this secondary in importance and value to the numerous other tasks needed for carrying out the assessment.

SHIP DATA

Ship data were determined to be the most useful of the various data sets for assessing the spatial distribution of the wind energy resource, its seasonal variability, and the steadiness and directional characteristics of the wind resource. Summaries of ship observations are available from the U.S. National Climatic Data Center (Hatch 1983), for $1^{\circ}$ latitude by $1^{\circ}$ longitude quadrangles. The summaries include monthly means and standard deviations of wind speed, pressure, temperature, wind directional frequency and speed, and other meteorological observations. Figure 2 shows the coverage of the ship data for the Caribbean and Central America region, based on data summarized up through the year 1970. Grid cells with 600 or more observations are considered generally useful, those with 300 to 600 are considered of marginal use, and those with less than 300 observations are generally not useful. of course, the ship observations only apply to portions of a grid cell that are over water. (The few grid cells that are entirely over land are out of place and are probably due to coding or keying errors in a ship's location coordinates.) Major shipping routes are apparent in Figure 2, as wel1 as areas avoided by ships such as the Great Bahama Bank. Although the ship observations began in some areas as early as the late 1800s, most of the data are from the 1940 s to 1970. The major advantages of ship wind data for use in wind resource assessments over vast ocean/island regions such as the Caribbean are the extensive geographic coverage of the ship data and the generally excellent exposure to winds from all directions. In this respect, the ship wind data can be used to determine the relative magnitude, direction, and frequency of the prevailing power-producing winds and to estimate the wind resource at coastal and inland sites that are well-exposed to the directions of the prevailing power-producing winds. 


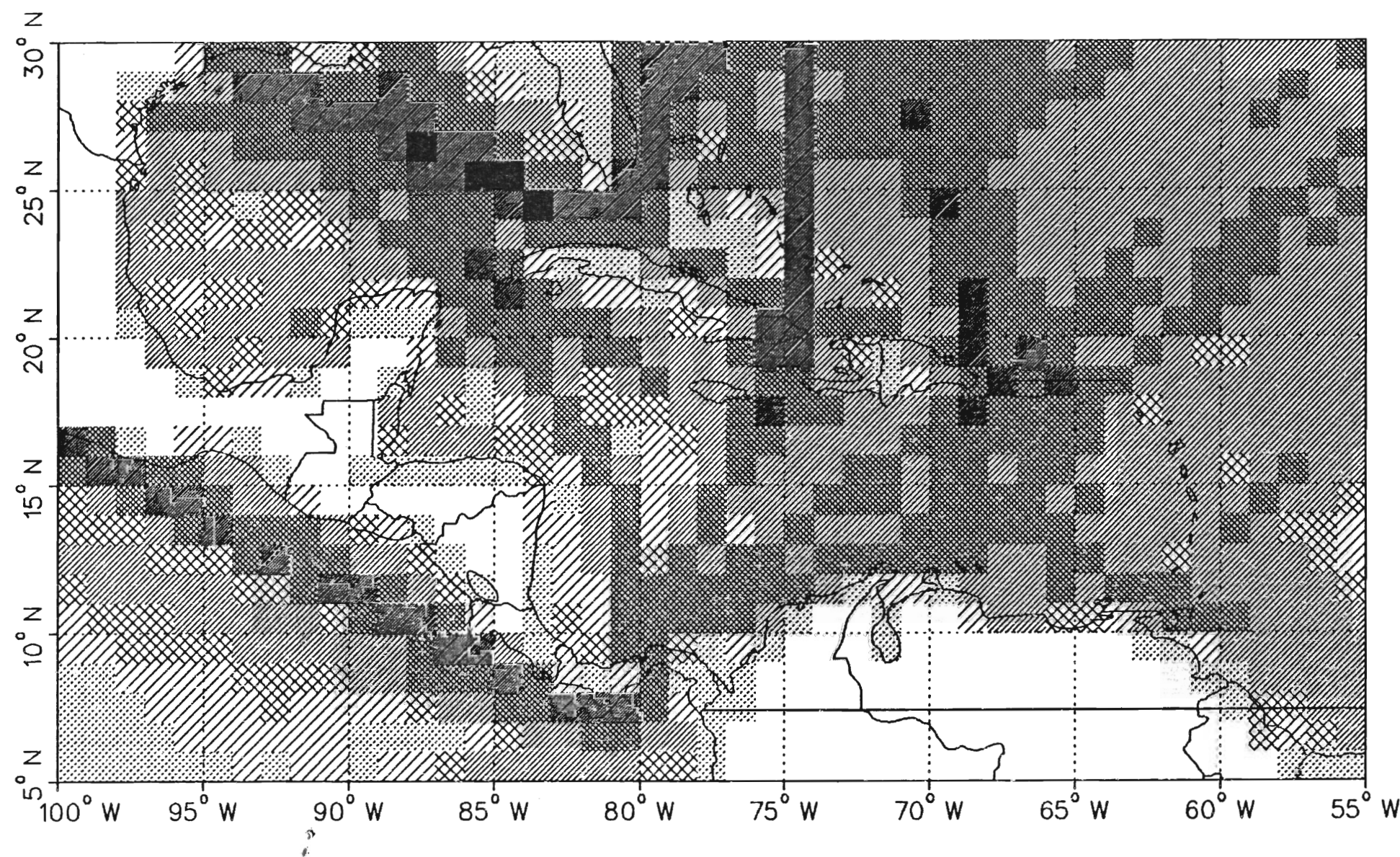

NUMBER OF OBSERVATIONS

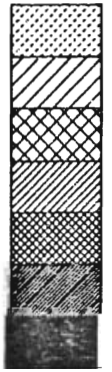

300.00 and below 300.00 to 600.00 600.00 to 1000.00 1000.00 to 3000.00 3000.00 to 10000.00 10000.00 to 30000.00 30000.00 and above

FIGURE 2. Ship Wind Observations in the Caribbean Region. Period of Record - Late 1800s to 1970 
PREVAILING DIRECTIONS OF POWER-PRODUCING WINDS

Figure 3 shows the prevailing directions of power-producing winds in January throughout the region, based on an analysis of the $1^{\circ}$ ship data. The mean scalar wind speed, averaged over all directions, is denoted by the type of arrowhead and the length of the tail. Blank areas without arrowheads represent either areas with insufficient ship data, such as the Great Bahama Bank, or land areas. The tip of an arrowhead is always plotted at the center of the $1^{\circ}$ grid cell; however, the data only represent that portion of the grid cell over water. This type of analysis permits one to readily identify characteristic flow features of the prevailing power-producing winds and the relative magnitude of the winds. For example, throughout most of the Caribbean, prevailing power-producing winds in January are indicated to be from the northeasterly sector and mean wind speeds generally exceed $6 \mathrm{~m} / \mathrm{s}$ in most areas and $7 \mathrm{~m} / \mathrm{s}$ in many areas. Two very interesting flow features in January are the area of very strong northerly winds in Mexico's Gulf of Tehuantepec and the area of strong northeasterly winds over the Pacific Coast of northern Costa Rica and southern Nicaragua. Figure 4 shows the prevailing directions of power-producing winds in July. As might be expected, flow features in July are somewhat different from those in January.

\section{WIND SPEED FEATURES}

Figure 5 shows a gridded map of the mean annual wind speeds for the $1^{\circ}$ ship data. Blank areas represent grid cells which have insufficient ship observations. A subjective analysis of the mean annual wind speeds is shown in Figure 6 . In producing this analysis, the analyst has used his skillful judgment and knowledge of island and terrain influences on the wind speed to draw the contours in areas with limited or questionable data and in areas where strong gradients exist. Many interesting features are apparent in Figure 6, such as the high wind speed area along the northern coast of Colombia that extends northward to the south cape of the Dominican Republic, and the high wind speed tongues extending off the Pacific coasts of southern Mexico, Costa Rica and Nicaragua. Blocking effects and reduced wind speeds are apparent in the lee of large islands such as Cuba, Hispaniola, Jamaica, and Puerto Rico, and to some extent, in the lee of smaller islands such as the 


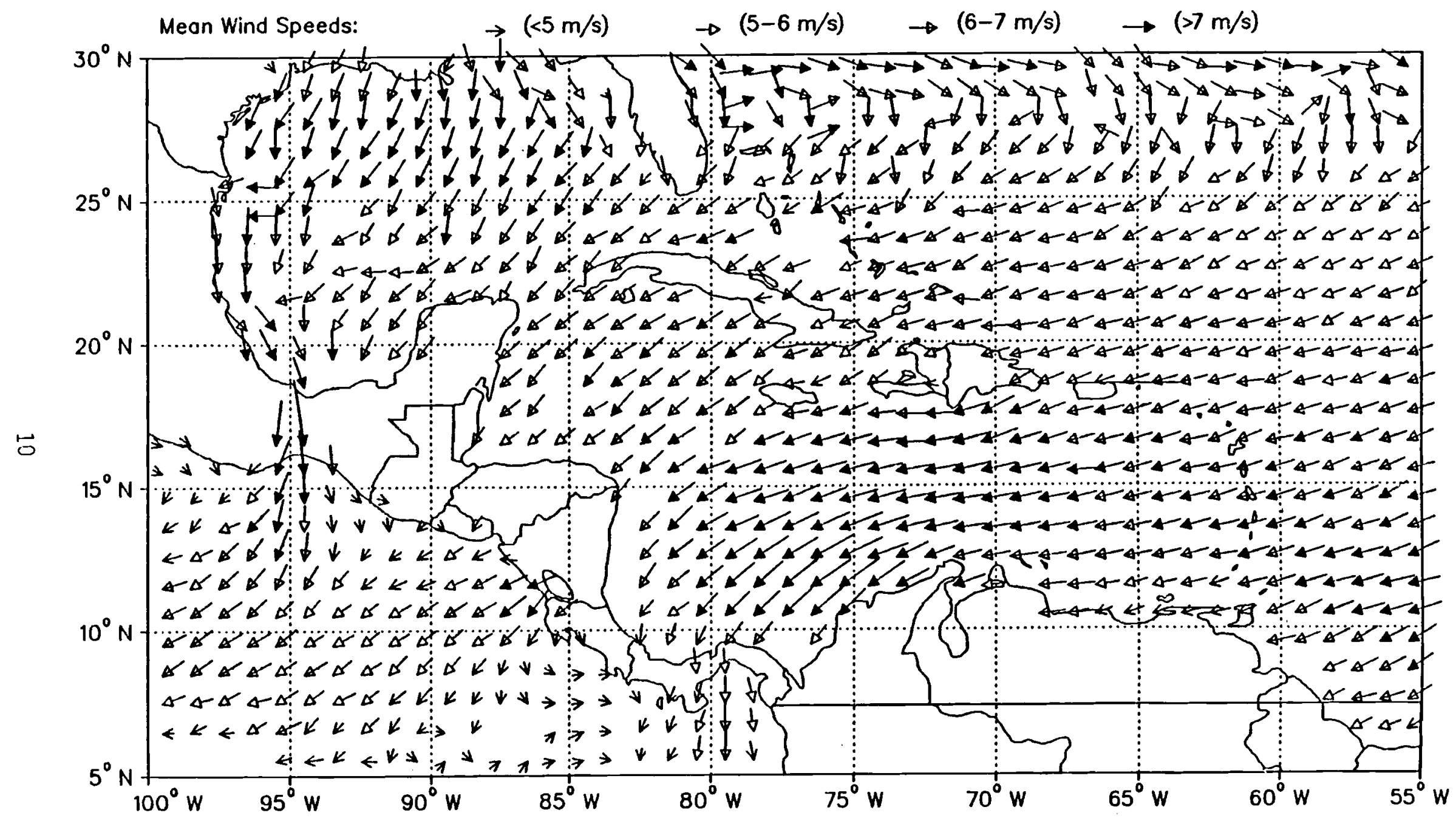

FIGURE 3. January: Prevailing Direction of Power-Producing Winds 


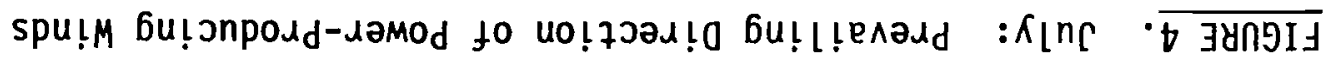

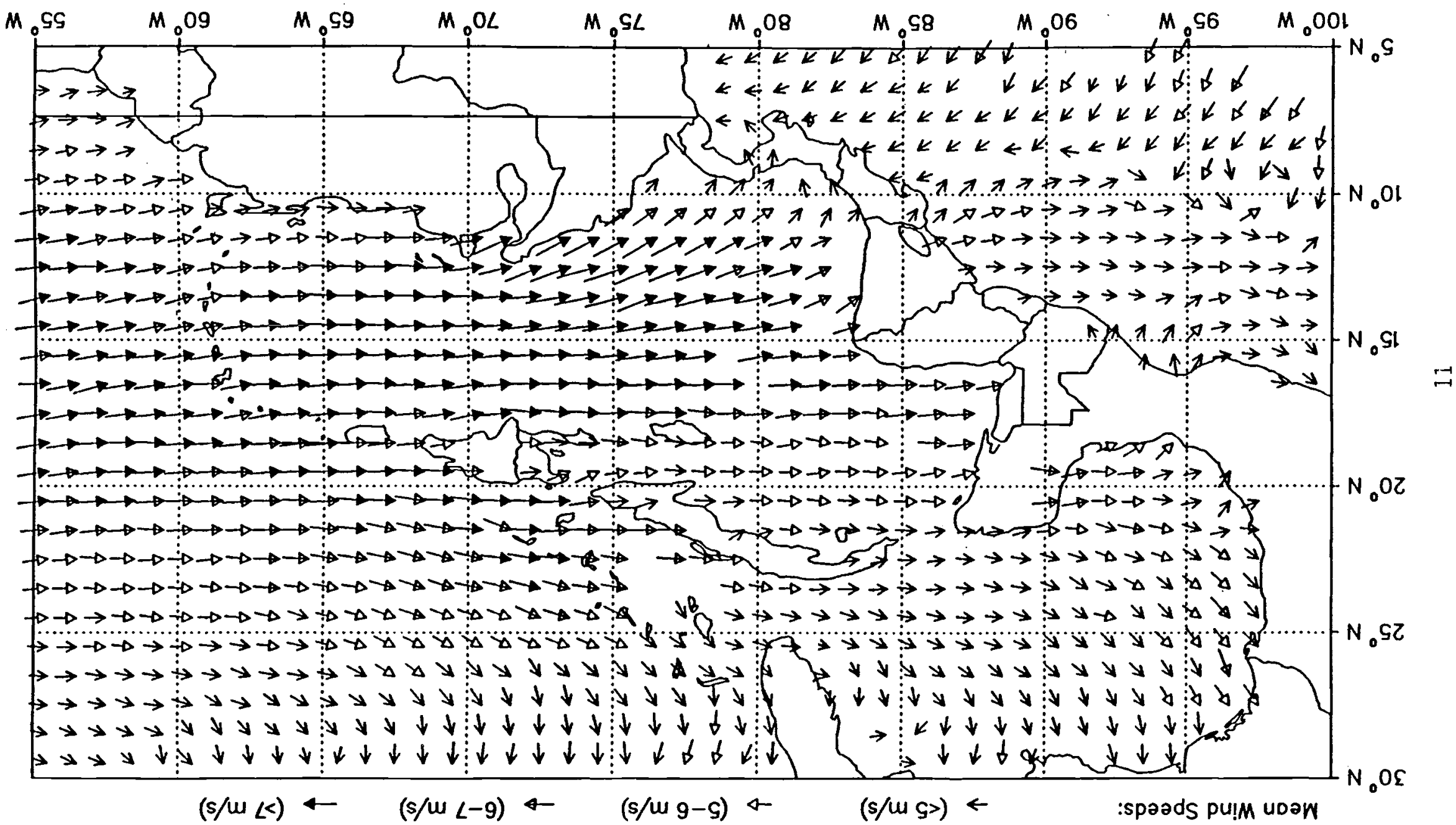




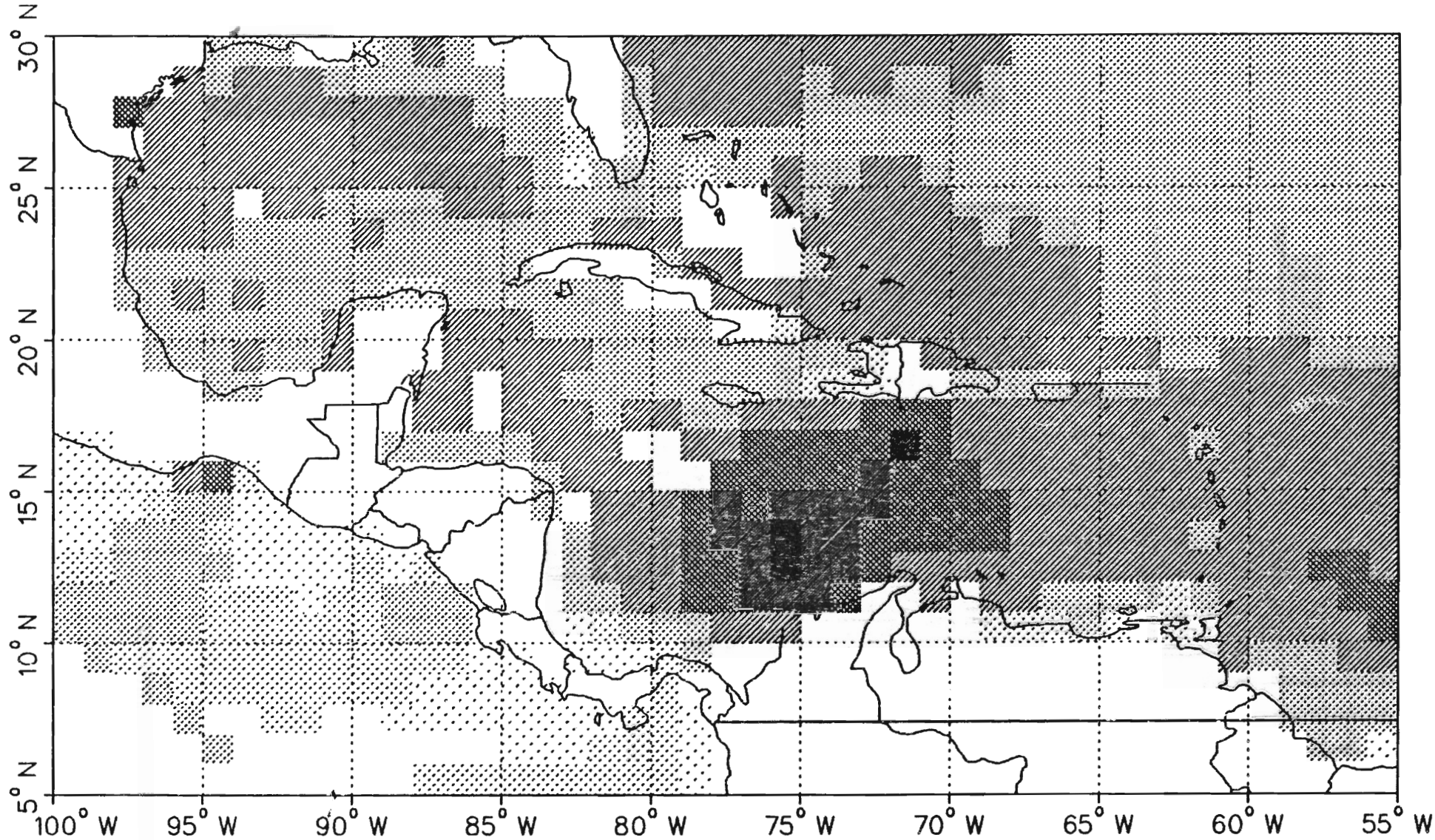

\section{Wind Speed}

$(\mathrm{m} / \mathrm{s})$

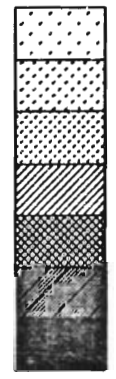

4.00 and below

4.00 to 5.00

5.00 to 6.00

6.00 to 7.00

7.00 to 8.00

FIGURE 5. Annual Average Wind Speeds for One-Degree Quadrangle

Marine Areas, Computed from Ship Wind Observations.

Blank (white) areas represent areas in which insufficient

8.00 to 9.00

or no ship data were available.

9.00 and above 


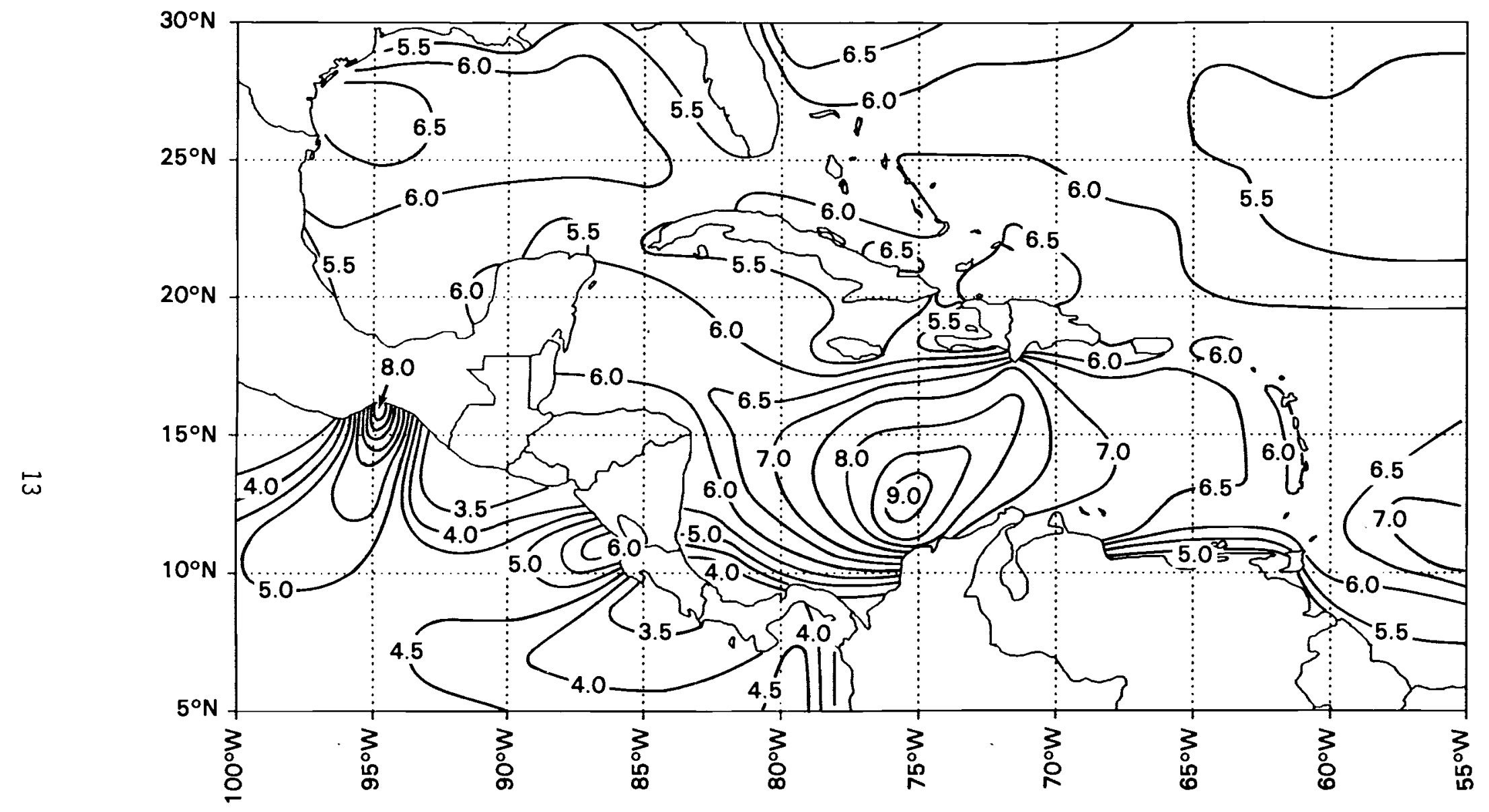

FIGURE 6. Annual Average Wind Speeds $(\mathrm{m} / \mathrm{s})$ for Marine Areas of the Caribbean, Derived from an Analysis of the One-Degree Quadrangle Ship Data 
Eastern Caribbean islands from Guadeloupe southward to Saint Vincent. One should keep in mind that seasonal features of wind speed can differ considerably from the annual average features.

\section{COMPUTING WIND POWER DENSITY}

Although the wind resource at a site is often described by the mean wind speed, the mean wind speed alone is not an adequate parameter to define the wind energy potential accurately. The energy in the wind is proportional to the sum of the cube of the instantaneous or short-term (e.g., hourly) average wind speeds and the air density. If hourly wind data are available, the mean wind energy flux, which is also referred to as the wind power density, can be computed from:

$$
E=\frac{1}{2 n} \sum_{i=1}^{n} \rho_{i} v_{i}^{3}
$$

where

$E=$ the mean wind power density $\left(\mathrm{W} / \mathrm{m}^{2}\right)$ in a vertical plane perpendicular to the wind direction

$\mathrm{n}=$ the number of observations in the averaging period

$\rho_{i}=$ the air density $\left(\mathrm{kg} / \mathrm{m}^{3}\right)$ at the $i$ th observation time

$v_{i}=$ the wind speed $(\mathrm{m} / \mathrm{s})$ at the ith observation time.

Wind speed distribution summaries of the observed wind speeds are sometimes available. These are usually expressed as the frequency of wind speeds within several ranges of wind speed values, or intervals of wind speed. If a frequency distribution of the wind speed observations is available, then $E$ can be estimated from:

$$
E=\frac{1}{2} \rho \sum_{j=1}^{c} f_{j} v_{j}^{3}
$$


where
$\rho=$ the mean air density
$c=$ the number of wind speed intervals
$f_{j}=$ the frequency of occurrence of winds in the $j$ th interval
$v_{j}=$ the median wind speed of the $j$ th interval.

If the mean temperature ( $T$ ) and pressure (P) are available, then the mean air density can be computed by:

$$
\rho=P / R T
$$

where $R$ is a gas constant.

\section{THE WEIBULL DISTRIBUTION}

Many observed wind speed distributions can be reasonably fit by an analytical approximation of the distribution. One of the most commonly used model for approximating wind speed probability distribution functions is the Weibull function:

$$
F(V)=(k / c)(V / c)^{k-1} \exp \left[-(V / c)^{k}\right]
$$

where $c$ is a scale factor with units of wind speed and $k$ is a dimensionless shape factor, which is an indicator of the width of the distribution. The larger the value of $k$, the narrower is the distribution. Figure 7 is a plot of Weibull wind speed frequency distributions for various Weibull k values and a mean wind speed of $5.4 \mathrm{~m} / \mathrm{s}$ (12 mph). A k value of 2 is the Rayleigh distribution, which has been found to provide a reasonable approximation of the wind distributions at many stations in the contiguous U.S. (Justus et al. 1976). A k value of 3.6 gives an approximation to a Gaussian distribution.

If only the mean wind speed $(V)$ and the standard deviation $(\sigma)$ of the mean wind speed are available (as is the case with the summaries of the ship data), 


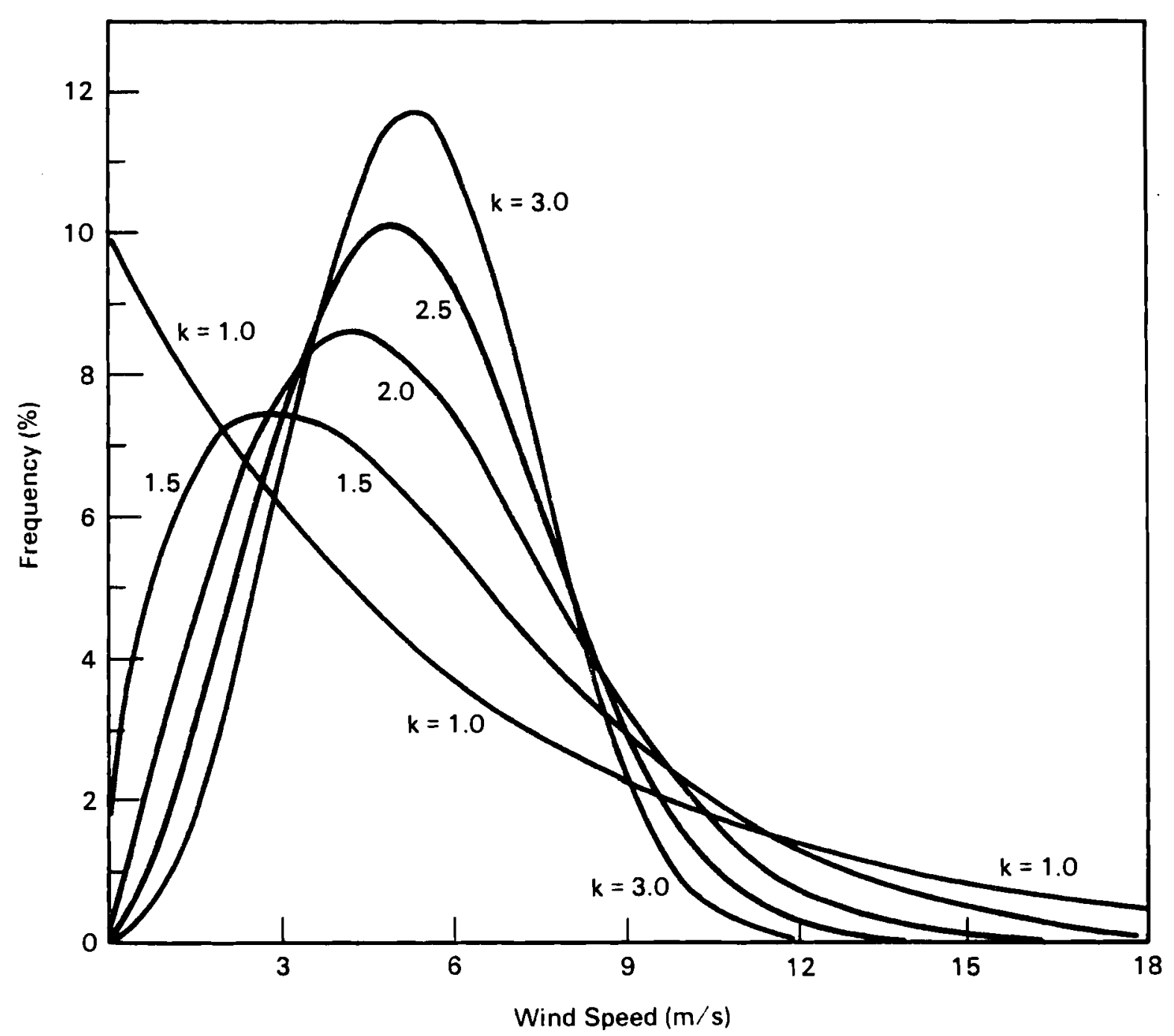

FIGURE 7. Wind Speed Frequency Distributions for Various Weibull k Values and a Mean Wind Speed of $5.4 \mathrm{~m} / \mathrm{s}$ (12 mph)

then the Weibull parameters $c$ and $k$ can be estimated using a method described by Justus et al. (1978) where $c$ and $k$ are related to $V$ and $\sigma$ by:

$$
\begin{gathered}
V=c \Gamma(1+1 / k) \\
(\sigma / V)^{2}=\left[\Gamma(1+2 / k) / \Gamma^{2}(1+1 / k)\right]-1
\end{gathered}
$$


where $\Gamma$ is the Gamma function and $\sigma / V$ is the coefficient of variation. The $c$ and $k$ values can also be found (Justus et al. 1978) by using the approximate relation for Equation (6):

$$
k=(\sigma / V)^{-1.086}
$$

and the inverse of Equation (5):

$$
c=V / \Gamma(1+1 / k) \text {. }
$$

Using the $1^{\circ}$ ship data summaries of the mean monthly wind speed and standard deviations and applying the method described above, we computed monthly mean values of Weibull $k$ and $c$ for marine areas of the region. The annual average Weibull $\mathrm{k}$ and $\mathrm{c}$ values were computed using the annual average wind speed and its standard deviation, which was calculated from:

$$
\sigma_{A}=\left[\frac{1}{n} \sum_{i=1}^{n}\left(\sigma_{i}^{2}+v_{i}^{2}\right)-v_{A}^{2}\right]^{1 / 2}
$$

where $n$ is the number of months, $\sigma_{j}$ is the standard deviation of the mean wind speed for month $i, v_{j}$ is the mean wind speed for month $i$, and $v_{A}$ is the annual average wind speed.

\section{WEIBULL $k$ FEATURES}

Figure 8 shows the subjective analysis of annual average Weibull $k$ values computed from the $1^{\circ}$ ship data. A wide range of annual average Weibull $k$ values is apparent throughout the region, with $k$ values ranging from less than 1.25 along the Pacific coast. of southern Mexico to 3.0 in the eastern Caribbean Sea. The relatively high $k$ values in the eastern Caribbean indicate a relatively narrow distribution of wind speeds about the mean, which is characteristic of the steadiness of the trade winds that persist throughout most of the year in this area. The low $k$ values, such as those found along the Mexican coasts and in the southwestern part of the region, indicate a very 


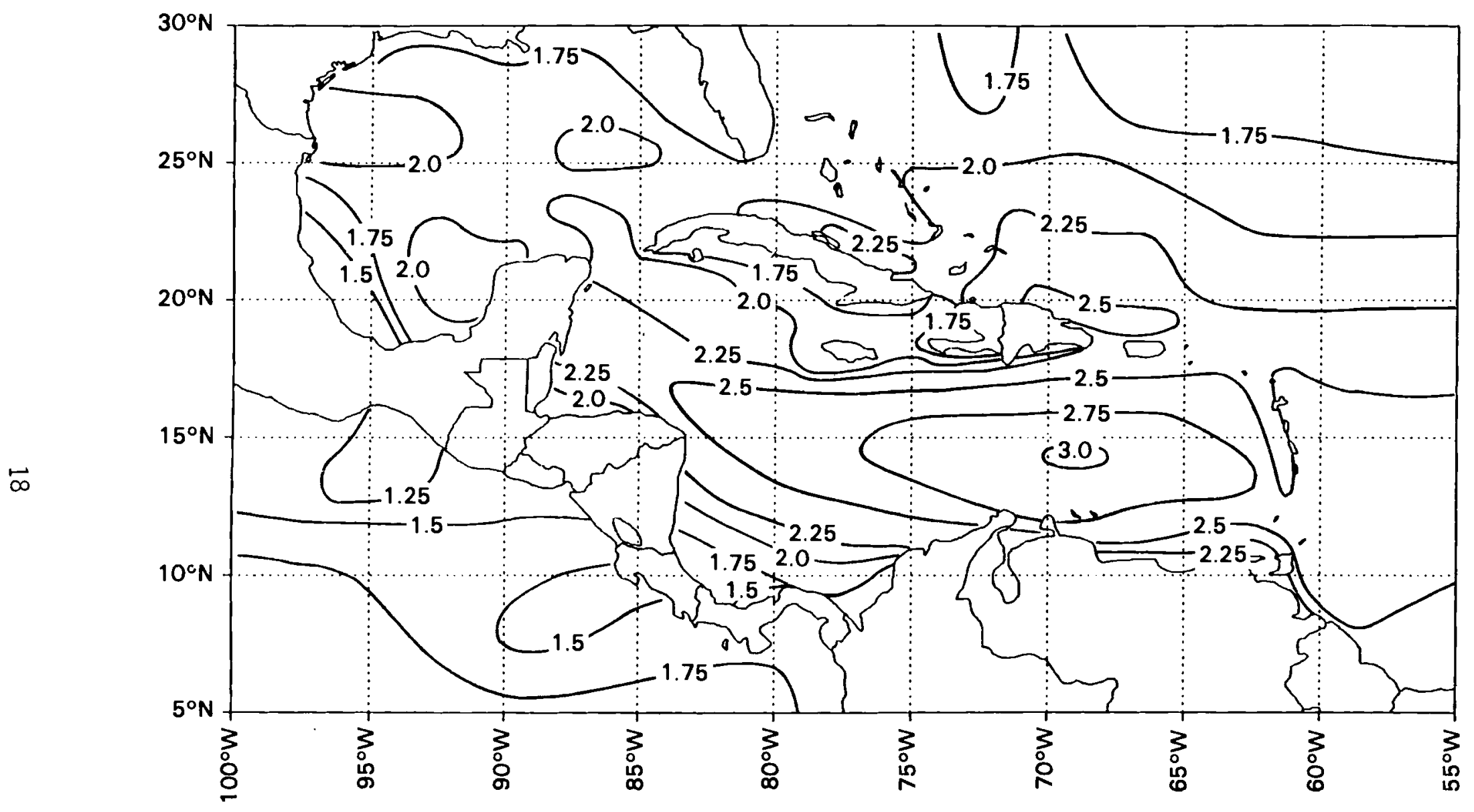

FIGURE 8. Annual Average Weibull k Values for Marine Areas of the Caribbean, Derived from an Analysis of the One-Degree Quadrangle Ship Data 
broad distribution of wind speeds (see Figure 7 ), which is characteristic of the large variations of wind speed that occur throughout the year in these areas. The range of $k$ values is even greater for the monthly data, with minimum $k$ values around 1.0 and maximum $k$ values around 4.0. The relative features of Weibull $\mathrm{k}$ values shown in Figure 8 have been determined to be quite accurate; however, these $k$ values must be corrected (as described later) because of inherent biases in the ship wind data.

\section{WIND ENERGY FEATURES}

Once $k$ has been determined, the mean wind power density $\left(W / m^{2}\right)$ can be computed from:

$$
E=\frac{1}{2} \rho V^{3}\left[\Gamma(1+3 / k) / \Gamma^{3}(1+1 / k)\right]
$$

The range of wind power densities can be described using a wind power class scale, such as that developed by Elliott and Barchet (1980) for use in the regional U.S. wind energy assessments. This wind power class scale is given in Table 1 for mean wind power densities at $10 \mathrm{~m}$ above ground, along with qualitative definitions of the various wind power classes.

TABLE 1. Classes of Wind Power Density at $10 \mathrm{~m}$

\begin{tabular}{|c|c|c|}
\hline $\begin{array}{l}\text { Wind } \\
\text { Power } \\
\text { Class } \\
\end{array}$ & $\begin{array}{c}\text { Wind Power } \\
\text { Density } \\
\left(W / m^{2}\right) \\
\end{array}$ & $\begin{array}{c}\text { General } \\
\text { Description }\end{array}$ \\
\hline 1 & $<100$ & Poor \\
\hline 2 & $100-150$ & Marginal \\
\hline 3 & $150-200$ & Useful \\
\hline 4 & $200-250$ & Good \\
\hline 5 & $250-300$ & Very Good \\
\hline 6 & $300-400$ & Excellent \\
\hline 7 & $>400$ & Superb \\
\hline
\end{tabular}


Figure 9 shows the analysis of the annual average wind power classes throughout the marine areas of the Caribbean and Central America region, based on the unadjusted ship data. This preliminary analysis of the wind energy potential indicates that good to superb wind energy resource exists throughout much of marine area of the region.

\section{METHODS FOR CORRECTING AND EXTRAPOLATING SHIP DATA}

The previous test has described the basic aspects of the data analysis and assessment methodology used to describe the general character and relative magnitude of the wind energy resource over marine areas of the Caribbean and Central America region. The next, and most difficult, parts of the assessment methodology were: (1) to evaluate the accuracy of the ship data and, if appropriate and feasible, develop a method for correcting the ship data; and (2) to establish methods for extrapolating the ship data to coastal and inland areas, considering terrain influences on the large-scale wind flow.

The reliability and accuracy of ship wind data have been the subject of several studies, e.g., Hinton and Wylie (1985), Graham (1982), Kaufeld (1981), Quayle (1980, 1974), and Verploegh (1967). Climatological mean wind speeds based on merchant ship observations usually represent a combination of speeds that are subjectively estimated from the state of sea conditions, using the Beaufort classification scale, and speeds that are measured by shipboard anemometers (Quayle 1980). Average anemometer height aboard merchant ships is approximately $25 \mathrm{~m}$ (World Meteorological Organization 1976). Historically, more than $80 \%$ of wind speeds from ships have been estimated rather than measured; however, the ratio of the number of measured to estimated winds varies from region to region and within a region (Quayle 1980). Although estimated winds are being increasingly replaced by measurements from shipboard anemometers, such estimates are no less reliable than actual shipboard measurements (Verploegh 1967 and Graham 1982). However, distributions of estimated wind speed observations are different from those derived from instrumental sources (Quayle 1980 and Graham 1982).

In our review of these various studies, we found somewhat different, and in some cases conflicting, methods proposed for correcting the mean wind speeds 


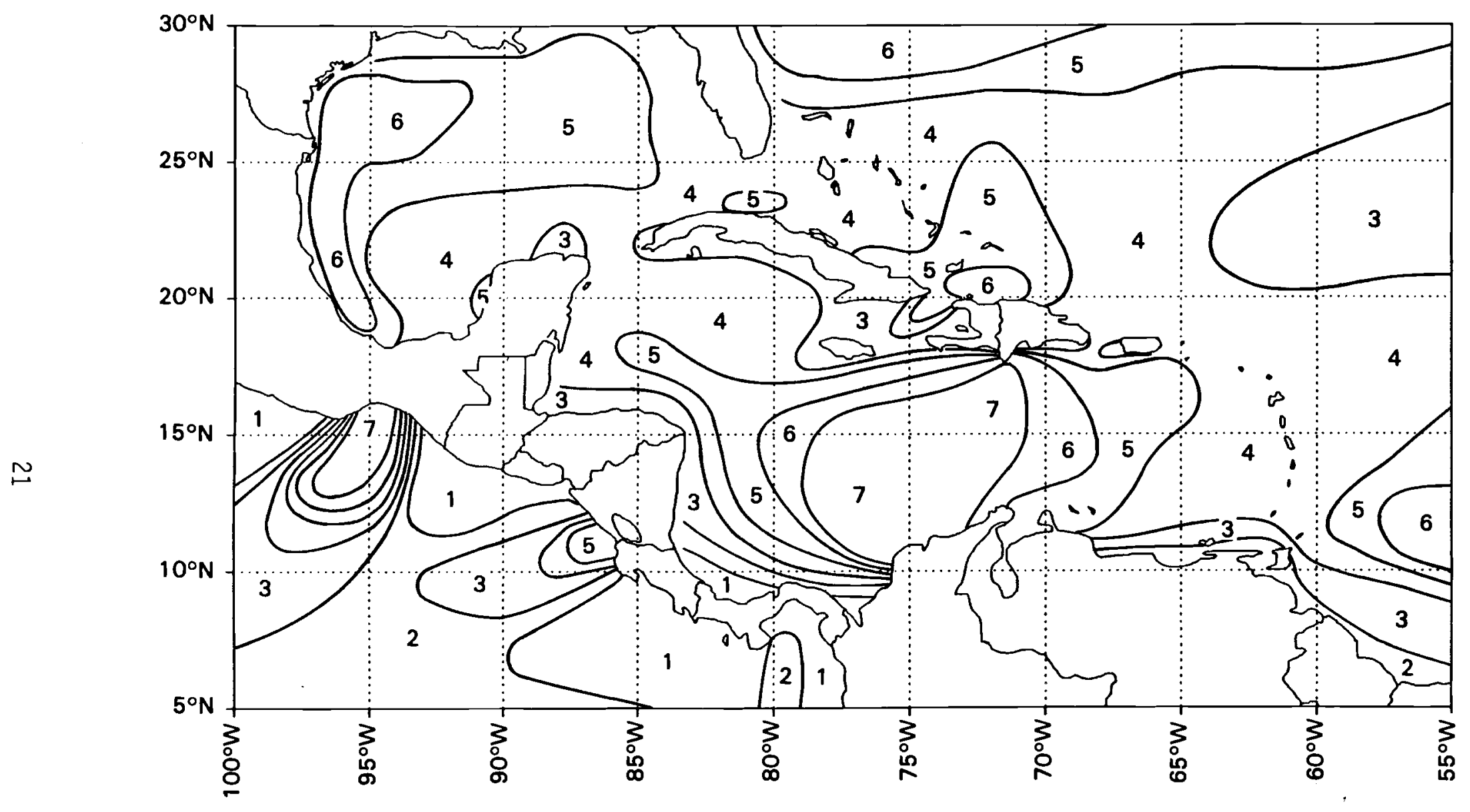

FIGURE 9. Annual Average Wind Power Classes for Marine Areas of the Caribbean, Derived from an Analysis of the One-Degree Quadrangle Ship Data. Classes are defined in Table 1. 
and speed distributions based on ship observations. Most of the data used in existing studies for evaluating the accuracy of transient ship data were fixed position observing stations, such as Ocean Weather Stations (OWS), and stationary buoys where the wind speeds were measured by an anemometer. Anemometer heights were around $25 \mathrm{~m}$ for OWS and $5 \mathrm{~m}$ to $10 \mathrm{~m}$ for buoys. However, these data were almost exclusively from middle and upper latitudes, since OWS data are nonexistent and fixed buoy data are sparse in tropical regions.

For these reasons, we pursued our own study to evaluate the accuracy of ship data for wind energy assessment in the Caribbean region. Also, we felt that a different type of analysis was needed that would be more appropriate for use in a wind energy assessment. For example, our primary concerns were: (1) Are the wind speed data based on ship observations reliable enough for use in a regional wind energy assessment of a tropical ocean/island region?, (2) What is the average height to which the wind data are applicable, or at least, most representative?, and (3) How accurate are Weibull k values based on ship observations?

\section{IDENTIFYING USEFUL DATA SETS FOR COMPARISON}

For the purpose of answering the concerns above, we identified data sets from the Caribbean that could be useful in evaluating the reliability and accuracy of the ship wind data, such as data from well-exposed sites on very small islands (e.g., only a few $\mathrm{km}$ in extent), atolls, or coastal points where terrain effects (such as island heating, topography, and roughness influences) on the prevailing ocean winds were determined to be small and relatively insignificant. Such sites typically have very small ranges in mean diurnal wind speeds, with diurnal ranges similar to the that of the ship data. Some buoy data were identified in the northern Gulf of Mexico (National Data Buoy Center 1986); although these data were not located in the primary areas of interest for the Caribbean and Central America assessment, they were thought to be of use. Eight exposed island sites were identified in the Caribbean region that met these criteria; the eight sites were scattered throughout the Caribbean, from the Bahamas to the eastern and western Caribbean areas. However, information on the frequency distribution of wind speeds, which is needed for estimating Weibull k values, was not available for four of the sites, so this 
further limited the amount of data for the Weibull k comparisons. With only a small amount of useful data in the Caribbean, we expanded the search for useful data to the Pacific Ocean tropical regions, screening data that had been previously summarized for use in a wind energy assessment of Pacific Islands affiliated with the United States (Schroeder et ai. 1981). Useful data sets were identified from five exposed sites on atolls and small islands and one fixed buoy (National Data Buoy Center 1986) in the tropical Pacific region.

\section{COMPARISON OF SITE AND SHIP DATA}

Using the wind data sets we had selected from the island and buoy sites in the Caribbean and the Pacific regions, we compared the annual and seasonal mean wind speeds and Weibull $\mathrm{k}$ values for the island and buoy sites with those based on the ship observations. (A detailed description of the systematic analysis of these data would be a study all of its own and is omitted here.)

Mean annual wind speeds of the island and buoy sites were all within $\pm 10 \%$ of the ship speeds and most were within $\pm 5 \%$, except for one site (Swan Island located in the western Caribbean) where the mean speed $(4.5 \mathrm{~m} / \mathrm{s}$ ) was $30 \%$ less than the ship mean $(6.3 \mathrm{~m} / \mathrm{s})$. Because the Swan Island site is such an anomaly, we suspect that its wind data may not be representative of an exposed site; however, we have no information on the reliability of the wind data or the exposure of the anemometer at this site. Anemometer heights were in the range of $6 \mathrm{~m}$ to $8 \mathrm{~m}$ for the Pacific island sites, $9 \mathrm{~m}$ to $15 \mathrm{~m}$ for the Caribbean island sites, and $5 \mathrm{~m}$ to $10 \mathrm{~m}$ for the buoys. An average anemometer height for all the sites is approximately $10 \mathrm{~m}$. Thus, on the average, mean wind speeds based on the ship observations appear to be applicable to a height of $10 \mathrm{~m}$. It is interesting to note that the Beaufort scale used to relate state of sea observations to wind speeds is, by definition, applicable to an anemometer height of $10 \mathrm{~m}$ (Quayle 1980). If we assume that the vast majority of the ship speeds in the Caribbean and Pacific trade wind region were estimated by 'sea state' observations using the Beaufort scale, these estimates for $10 \mathrm{~m}$ verify reasonably well with the mean wind speeds at approximately $10 \mathrm{~m}$ from exposed island and buoy sites. 
The Weibull k comparisons indicated some definite trends. Generally, site $k$ values exceeded ship $k$ values (denoted as $k_{s}$ ), except for low $k$ values where the limited data available indicated little difference. The largest differences in the Weibull $k$ values were at the higher $k$ values, which are characteristic of the steady trade-wind climates that exist throughout much of the Caribbean and Pacific region. We developed a method for correcting the Weibull $k_{s}$ values computed from the ship data, based on the analyses of the empirical relationships between the ship data and the site data from the island and buoy stations. Table 2 presents corrected Weibull k values for various Weibull $k_{s}$ values.

TABLE 2. Corrected Weibull $k$ Values for Various Weibull $k_{s}$ Values Corresponding Values of $k$ and $k_{s}$

$\begin{array}{llllllllllllllll}\mathrm{k}_{\mathrm{s}} & 1.6 & 1.7 & 1.8 & 1.9 & 2.0 & 2.1 & 2.2 & 2.3 & 2.4 & 2.5 & 2.6 & 2.7 & 2.8 & 2.9 & 3.0 \\ \mathrm{k} & 1.6 & 1.8 & 2.0 & 2.2 & 2.4 & 2.5 & 2.6 & 2.8 & 3.0 & 3.2 & 3.4 & 3.6 & 3.8 & 4.0 & 4.2\end{array}$

For $1.0 \leq k_{s} \leq 1.6, \quad k=k_{s}$.

EXTRAPOLATING SHIP DATA TO COASTAL AND INLAND AREAS

Extrapolating the corrected ship wind data to estimate the wind energy resource at coastal and inland areas requires a comprehensive knowledge of the terrain influences on the large-scale air flow and the effects of this on the mean wind speeds and Weibull $k$ values. Topographical indicators of wind power potential, such as those previously developed for use in wind energy resource assessments and siting applications (Elliott 1979, Pacific Northwest Laboratory 1980-1981, Hiester and Pennell 1981), were used to make qualitative estimates of the effects of terrain influences on the large-scale wind flow and the geographical distribution of the wind resource. Where possible, the estimates of the wind energy resource were compared with existing site data. The estimates were revised, where necessary, to verify with the existing site data, if the data were judged to be from a representative, exposed site. In most areas where representative data were available, the estimates were comparable to the measured wind resource. 
Topographic maps depicting contours of elevation are imperative for use in estimating terrain influences on the wind flow. Aeronautical charts (NOAA 1985), which include elevation contours, shaded relief, and names and locations of major towns and prominent geographic features, were used for this purpose and also for portraying the geographical distribution of the wind resource estimates. These charts were also valuable in appraising the usefulness and applicability of existing wind data from airfields and other locations, which could be readily located since the charts depict airfield locations and include latitude and longitude lines.

Another essential input needed to extrapolate the ship wind data is information for characterizing the large-scale wind flow, such as monthly mean data on wind direction and force. For this, monthly maps of the prevailing directions of power-producing winds and mean wind speeds, based on our analyses of the one-degree ship data, were quite useful. These data were supplemented by wind rose data for marine areas based on ship observations (e.g., from Naval Oceanography Command 1985-1986), and for airfields and other surface stations that were available from various data summaries and climatological reports obtained for the region.

Our knowledge of various types of topographical indicators was applied in estimating terrain influences on the large-scale wind flow and the distribution of the wind resource. Indicators were applied for three major topography groups: flat terrain, small-scale terrain, and large-scale terrain (Hiester and Pennell 1981).

\section{FLAT TERRAIN INFLUENCES ON THE FLOW}

In some areas of the Caribbean, such as the much of the Bahamas, we only needed to consider flat terrain influences on the large-scale wind flow, such as the effects of sea breeze circulations, roughness changes (e.g., from smooth ocean onto densely forested land), and daytime heating and nocturnal cooling on the air flow in the near-surface boundary layer. The sea breeze, though well understood in principle, is sensitive to many parameters including synoptic flow conditions, coastal shape and topography, and seasonal variations in solar heating. In the Caribbean trade-wind regions, the sea breeze effect 
enhances the daytime trade-wind flow on the windward (eastern) coasts and reduces the flow on the leeward (western) coasts. At night, effects of land breezes and nocturnal stability can reduce the near-surface trade-wind flow at coastal sites. The combined effect is such that the mean wind resource on windward-facing coasts (excluding very small or narrow islands) is usually less than the ambient flow in areas of light-to-moderate ambient flow, approximately equal to the ambient flow in areas of moderate-to-strong ambient flow, and greater than the ambient flow in areas of very strong ambient flow. In coastal areas where the mean wind resource is only marginal, the sea breeze may be useful as a wind resource if the seasonal and diurnal characteristics of the sea breeze match the anticipated electrical load.

Increases in the roughness height, such as flow from smooth ocean onto densely forested land, causes a deceleration of the near-surface flow as it encounters the increased drag of the forest. Thus, in areas of high roughness the wind resource immediately inland $(<1 \mathrm{~km})$ of the exposed coastline may be considerably less than that at the coastline. In the island/country wind power analyses, the coastal estimates are applicable to well-exposed sites.

Further inland, the combined effects of nocturnal stability and roughness can drastically reduce the mean wind resource from that of coastal areas. Even over regions where large-scale trade wind flow is quite strong, such as much of the eastern Caribbean, the mean wind resource over flat, inland areas of islands may only be low to marginal (e.g., the interior of Grand-Terre on Guadeloupe). In such areas, winds from near sunset to a few hours after sunrise are usually light, as nocturnal stability effects cause the strong winds aloft to become decoupled from the near-surface layer. During the daytime, however, the wind resource may be quite useful, as the strong winds aloft are mixed down to the surface.

\section{SMALL-SCALE TERRAIN INFLUENCES ON THE FLOW}

In other areas of the Caribbean, we had to consider small-scale terrain influences as well as flat terrain influences. A topographical feature is defined as small when it is relatively small compared to the depth of the 
planetary boundary layer. Thus, while there may be some acceleration over or around a small-scale terrain feature, it is not a 'major' obstacle to flow in the boundary layer. For example, the average depth of the primary trade-wind flow in the eastern Caribbean is approximately 1500 to $2000 \mathrm{~m}$ (varying seasonally), with maximum winds generally between 500 to $1500 \mathrm{~m}$ (Wegley et al. 1981). Elevated terrain features, such as hills or ridges, that are only 100 to 300 $m$ in height would be considered small-scale terrain features, as these features do not represent a major obstacle to the large-scale wind flow in the tradewind boundary layer. However, these small-scale terrain features are important from a wind energy perspective, as the wind over these elevated terrain features is generally stronger than over nearby flat country. Moreover, a ridge crest can experience considerable acceleration of the ambient flow, depending on the shape, slope, and orientation of the ridge to the prevailing powerproducing winds. Many islands in the Caribbean have a combination of flat and small-scale terrain features, such as Antigua, Aruba, Barbados, Bonaire, and Curacao. In the island/country assessment maps, we have depicted the wind energy resource estimates for many smal1-scale terrain features, such as prominent ridges and hills that have been identified using 1:500,000 scale aeronautical charts. These charts indicate contours of elevation at $250 \mathrm{ft}$ $(76 \mathrm{~m})$ and $500 \mathrm{ft}(152 \mathrm{~m})$, then in 500-ft intervals, which allowed us to identify small-scale terrain features that were at least on the order of 100 to $150 \mathrm{~m}$ higher elevation than nearby areas.

\section{LARGE-SCALE TERRAIN INFLUENCES ON THE FLOW}

Large-scale terrain features have vertical dimensions that are a significant fraction of or exceed the depth of the boundary-layer air flow. These include elevated features such as large mountains, ridges, and cordillera (an extensive range of mountains) that primarily block or divert the largescale air flow. Many of the eastern Caribbean islands have mountains or ridges that exceed $600 \mathrm{~m}(2000 \mathrm{ft})$ and reach nearly $1500 \mathrm{~m}(5000 \mathrm{ft})$ on a few of the islands. Such mountains are major barriers to the trade-wind flow, diverting large volumes of the air flow around the barrier or through major gaps or passes that may exist in the barrier. Areas of enhanced wind resource usually occur where the flow is diverted around the corners of a mountain barrier or 
where the flow is channeled over a major gap or pass in the mountain barrier. on the island/country wind resource maps, we indicate where such areas may exist and provide estimates of the wind resource for the areas, based largely on our interpretation of how the topography affects the large-scale ambient flow and on experience gained through observation.

On some islands, a combination of flat, smal1-scale, and large-scale terrain provides for some interesting, and often complicated, wind energy analyses. Areas of super-enhanced flow may exist where there are combined accelerations from large-scale and small-scale terrain influences or between two large-scale features. Such areas of super-enhanced flow, caused by these types of combined accelerations, have been verified in Hawaii. For example, on island of Hawaif, low-level flow that is diverted to the north around Mauna Kea $(4200 \mathrm{~m})$ undergoes an additional acceleration as it flows over the Kohala ridge, causing an area of super-enhanced flow along the Kohala ridge.

Major diversions of the trade wind flow around large and extensive mountain barriers in the Caribbean are apparent in the analyses of the ship wind data (e.g., Figures 3, 4, and 6). For example, the island of Hispaniola (consisting of the Dominican Republic and Haiti) has extensive mountain ranges from 1000 to $3000 \mathrm{~m}$ in elevation that create a major obstacle to the largescale trade-wind flow. Analyses of the monthly ship data in the vicinity of Hispaniola shows evidence of enhanced flow around northern and southern coastal areas of Hispaniola and substantially reduced flow in the wake of the island. The areas of enhanced speeds vary seasonally in intensity and in location due to seasonal variations in the strength and direction of the prevailing trade winds. In the island/country wind resource assessments, we have estimated seasonal variations in the wind resource (e.g., months of maximum and minimum wind power), based on our analyses and interpretation of terrain influences on the seasonal wind flow.

\section{THERMAL EFFECTS ON THE FLOW}

In addition to large-scale terrain channeling and blocking effects, thermal effects of large mountains and ridges can also modify the flow. Mountains can become elevated heat sources during the day, causing the formation of 
upslope winds, and cold sources at night that cause the formation of downslope winds. Such thermal effects and their modification of the large-scale wind flow are greater on the larger mountainous islands than on smaller islands and are usually more pronounced in the interior of an island than near the coastal fringes. Although thermal effects may at times enhance the trade wind flow, their overall effect is to reduce the mean trade wind flow. Thermal effects on the air flow were considered in developing the wind power estimates.

\section{ESTIMATING THE WIND RESOURCE IN CENTRAL AMERICA}

In the above sections, we have primarily described how terrain influences of various island types can modify the large-scale wind flow and how various topographical indicators can be used to estimate coastal and island wind resource distributions. We have used the ship wind data to estimate the largescale flow. However, in Central America, the application of ship wind data is primarily limited to coastal areas, and we must use other techniques in an effort to estimate the wind resource distribution throughout the interior areas of Central America. Existing wind data from airfields and weather stations in the interior areas of Central America are very limited for their use in a wind energy assessment, because most of these stations are in sheltered locations such as valleys and basins. In our efforts to develop a technique that could be useful in estimating the seasonal and annual wind resource distribution in Central America, we more closely examined the climatology and topography of the region in an effort to define the general wind flow features and determine the processes responsible for these features. The analyses of the ship wind data indicated two high wind areas along the Pacific coast of Central America (see Figure 6). The highest wind resource in these areas occurs in the winter season. Directional data (see Figure 3) show that the prevailing power-producing winds in these two areas blow offshore (from land over water) on the Pacific coast and extend seaward for more than $100 \mathrm{~km}$. An inspection of the Central America topography reveals that these two areas are downwind of major gaps in the Central America cordillera, an extensive system of high mountain ranges that extend from Mexico to Panama, suggesting that these two major gaps are wind corridors. Existing surface data from inland stations located in these gaps also indicate that wind corridors may exist in these areas, but the stations indicate substantially lower speeds than would 
be expected for an exposed site, based on the analysis and extrapolation of the ship wind data. Further analysis of the local terrain features in the vicinity of the stations indicates that the stations are in locations that are somewhat sheltered from the prevailing directions of the power-producing winds.

\section{ANALYSIS OF THE PRESSURE GRADIENTS IN CENTRAL AMERICA}

To gain an understanding of the physical processes that may be responsible for the high winds in these corridors, we analyzed the large-scale surface pressure features over the region, using the monthly mean pressure data derived from the ship observations. Figure 10 shows the analysis of sea-level pressure for January. Mean sea-level pressures are significantly greater over the western Caribbean Sea and the Gulf of Mexico than over the Pacific. Largest differences are in southern Mexico, where mean pressure gradients across the Isthmus of Tehuantepec are approximately $4 \mathrm{mb}$. A major gap here through the mountains creates a powerful wind corridor, caused by the very strong pressure gradients. Mean January wind speeds in the Gulf of Tehuantepec are approximately $10 \mathrm{~m} / \mathrm{s}$. As shown in Figure 3, a tongue of strong northerly winds extends southward from the wind corridor in the Isthmus of Tehuantepec for hundreds of kilometers over the Pacific Ocean. However, an analysis of the Weibull $k$ values from the ship data and one station in the wind corridor indicates that these winds are not quasi-steady like the trade winds, but very sporadic. That is, these winds may be 'very' strong for days, followed by periods of light winds. This broad distribution in wind speeds is a result of large variations in the magnitude of the pressure gradients, which are largely in response to changes in the pressure that occur during the winter season in the Gulf of Mexico (Aleman and Garcia 1974).

Another major gap in the Central America cordillera occurs from southern Nicaragua to northern Costa Rica. Here, strong pressure gradients create another powerful wind corridor, about $300 \mathrm{~km}$ in width, from November to April when pressures over the western Caribbean are significantly greater than those over the Pacific. A secondary wind maximum occurs in July, caused by an increase of pressure in the western Caribbean in association with the midsummer intensification of the high pressure ridge over the Atlantic. The winds in this corridor are estimated to be more steady, and less variable, 


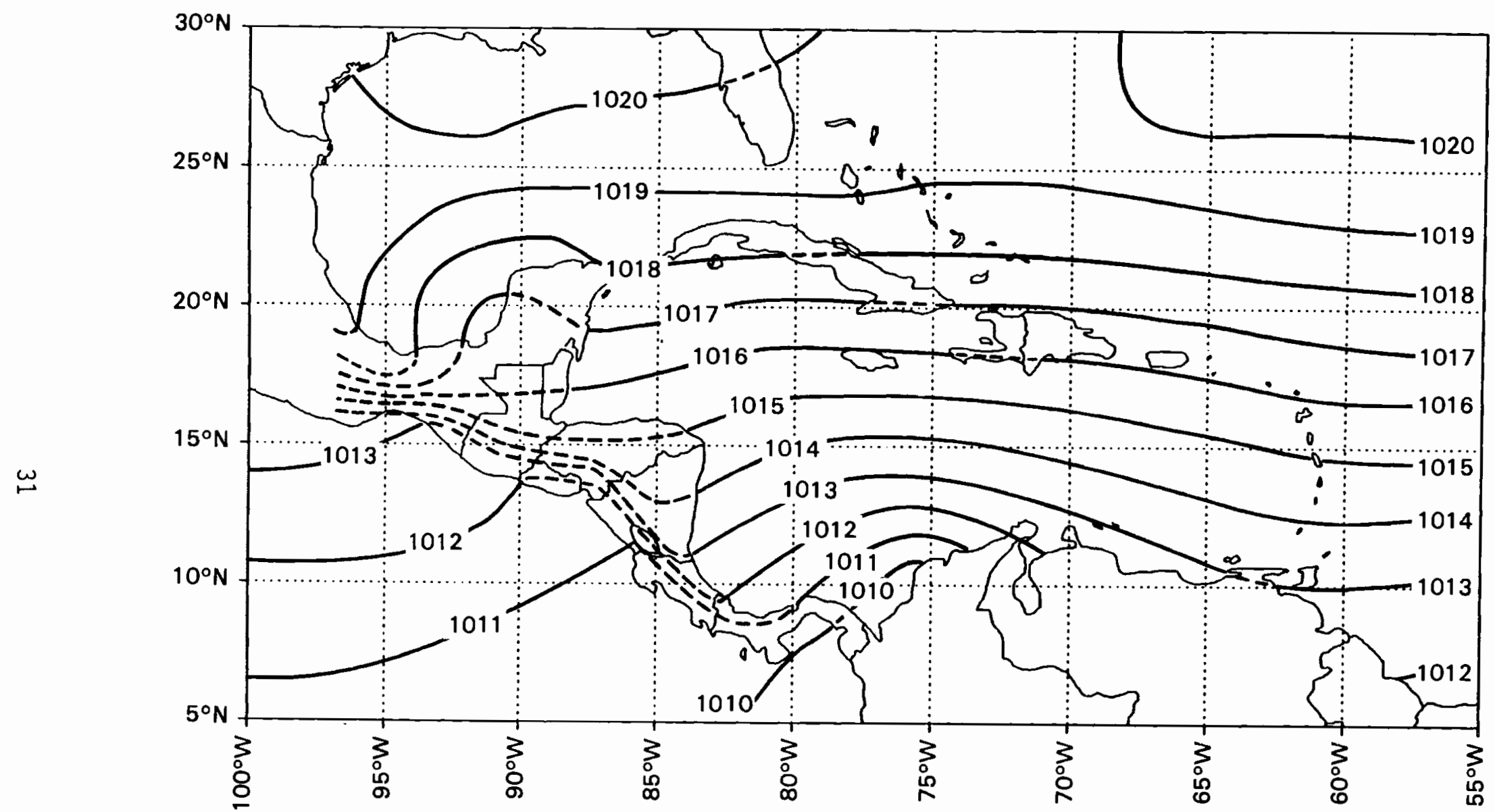

FIGURE 10. January Mean Sea-level Pressures (mb), Derived from an Analysis of the OneDegree Quadrangle Ship Data. Dashed lines are extrapolations to land areas. 
than those in the southern Mexico corridor, as pressure variations in this region of the western Caribbean are generally smaller than those in the Gulf of Mexico. This is confirmed by the analysis of monthly average Weibull k values (for the windy season), which are higher in this corridor area than in southern Mexico. However, the distribution of the wind resource throughout the corridor is estimated to be quite complex and varied, because of a wide variation of terrain features that modify the flow within the corridor.

Although another major gap in the Central America cordillera creates a wind corridor in central Panama, pressure gradients are weaker and winds are not as strong as those in the Costa Rica - Nicaragua wind corridor. However, our analysis indicates that good wind resource potential may be found from December to March at well-exposed locations in this wind corridor.

With such large pressure gradients evident during the winter season throughout much of Central America, we speculated that additional wind corridors of smaller extent may exist. We studied the topographic maps and applied our knowledge of how the pressure gradients would affect the flow in these mountainous areas. Based on this analysis, we identified many small-scale wind corridors from Guatemala to Panama. Small-scale, in this context, means that the corridors are mostly 5 to $20 \mathrm{~km}$ in extent, which is comparable in extent to many of the wind corridors in California, such as the Altamont and San Gorgonio Pass areas where thousands of wind turbines have been installed. In a few cases, existing station data were available for use in verifying the existence of a wind corridor (e.g., near San Jose, Costa Rica and Guatemala City, Guatemala). 


\section{THE WIND ENERGY RESOURCE MAPS}

Wind energy resource maps are presented for 35 island/country areas throughout the Caribbean and Central America. The maps are arranged by island groups or regions as shown in Table 3. (For the page number of a selected region, refer to the Table of Contents.) The wind resource maps highlight major wind resource areas and provide estimates of the annual average wind energy resource potential for well-exposed locations in these areas. A table is presented with each map that includes information on weibull $k$ values and seasonal variations in the wind resource for the major areas identified on the maps. A new wind power class legend has been developed (see Figure 11) for relating the wind power classes and Weibull $k$ values given on the maps and tables to values of mean wind power density and mean wind speed. Guidelines are presented below on how to most effectively use and interpret the island/country wind resource maps and tables. For a broader understanding of air flow and terrain interactions that are pertinent to wind energy assessment in the Caribbean and Central America, one is encouraged to review previous sections of this report which discuss terrain influences on the wind flow. Siting documents, such as those written by Pennell (1983), Hiester and Pennell (1981), and Wegley et al. (1980), can assist a potential user in going from wind resource assessment to site selection.

\section{USING AND INTERPRETING THE ISLAND/COUNTRY WIND RESOURCE MAPS}

The island/country maps provide estimates of annual average wind power classes at heights of $10 \mathrm{~m}$ above ground for locations that are we 11 exposed to the prevailing power-producing winds. The wind power classes are defined in Figure 11 , in relation to the mean wind power density $\left(W / \mathrm{m}^{2}\right)$ and qualitative definitions of the wind power. Class 1 is considered poor, class 2 marginal, and class 3 useful for many applications. Class 4 is generally good for most applications and classes 5 and above are better yet.

As can be seen in Figure 11, information on the Weibull shape factor, $k$, is needed to relate the wind power classes to a mean wind speed at $10 \mathrm{~m}$. What is obvious in this figure is the large range of mean wind speeds that are possible for a given mean wind power density over the range of Weibull k 
TABLE 3. Listing and Arrangement of the 35 Island/Country Wind Energy Resource Maps for the Caribbean and Central America Region

Eastern Caribbean - Lesser Antilles (11 maps)

Grenada

St. Vincent and the Grenadines

Barbados

St. Lucia

Martinique

Dominica

Guadeloupe

Antigua, Barbuda, and Montserrat

Nevis, Saba, St. Christopher, and Sint Eustatius

Anguilla, St. Barthelemy, and St. Martin

Virgin Islands

Greater Antilles (6 maps)

Puerto Rico

Dominican Republic

Haiti

Jamaica

Cayman Islands

Cuba

Bahamas, Turks and Caicos Is lands (6 maps)

Bahamas - Grand Bahama and Great Abaco Islands

Bahamas - Andros, Berry, and New Providence

Bahamas - Cat, Eleuthera, and Great Exuma Islands

Bahamas - Acklins, Crooked, Long, and San Salvador Islands

Bahamas - Inagua and Mayaguana Islands

Turks and Caicos Islands

Southern Caribbean Coast and Islands (4 maps)

Aruba, Bonaire, and Curacao

Trinidad and Tobago

Venezuela Coast and Islands

Colombia Coast and Islands

Central America and Southern Mexico (8 maps)

Panama

Costa Rica

Ni caragua

Honduras

El Salvador

Guatemala

Belize

Southern Mexico 


\section{CLASSES ( 1 TO $7+++)$ OF WIND POWER DENSITY $\left(\mathrm{W} / \mathrm{m}^{2}\right)$ AT $10 \mathrm{~m}$}

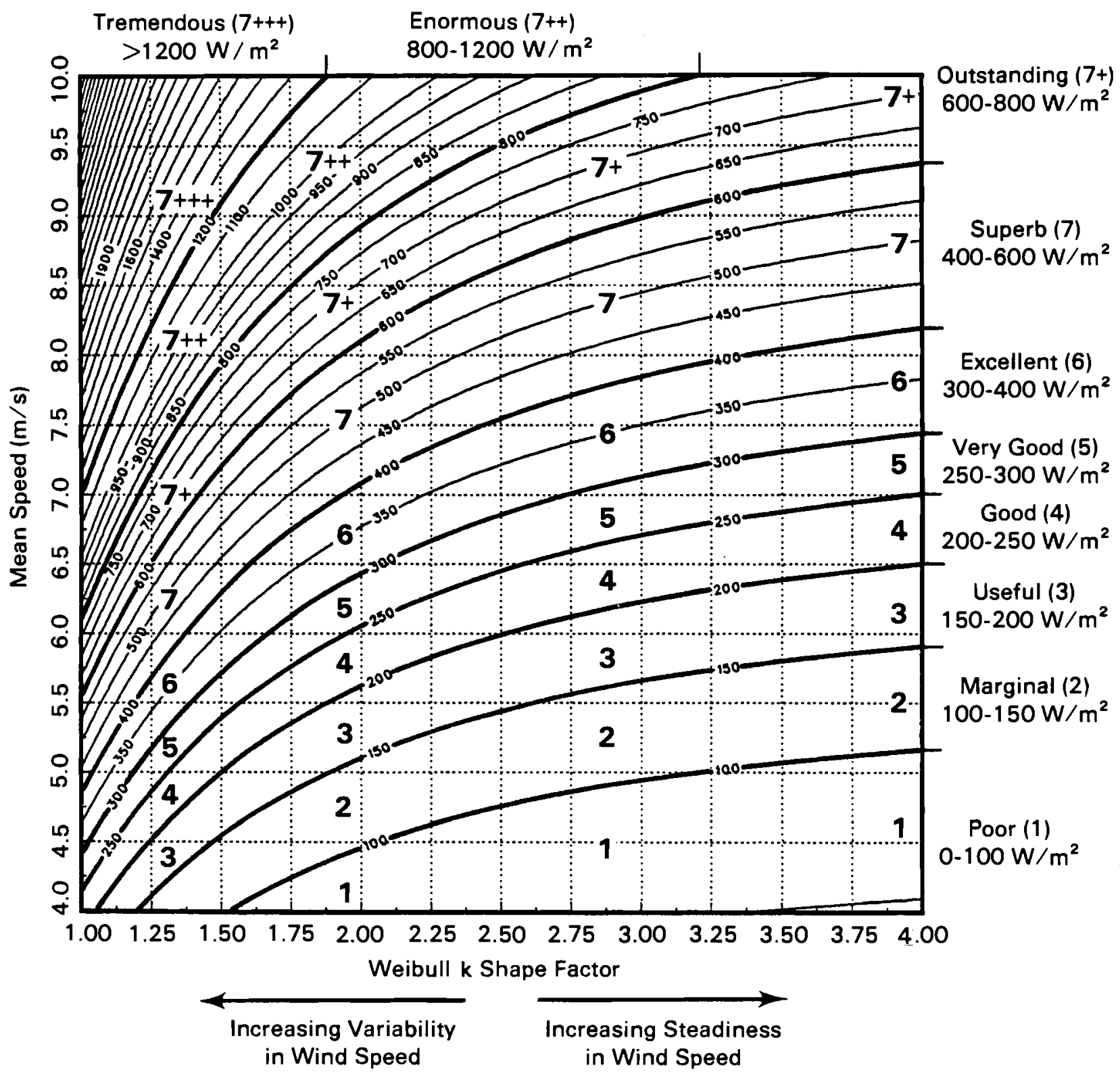

FIGURE 11. Wind Power Class Legend for Relating Values of Mean Wind Power Density $\left(\mathrm{W} / \mathrm{m}^{2}\right)$, Weibull $k$, and Mean Wind Speed $(\mathrm{m} / \mathrm{s})$. The wind power classes, which range from 1 to $7+++$, correspond to intervals of mean wind power density at $10 \mathrm{~m}$ that are specified along the right and top sides of the figure. Qualitative descriptions of each wind power class are also included. 
values, which is typical of the range of Weibull $k$ values that exist throughout the Caribbean. For example, for a mean wind power density of $250 \mathrm{~W} / \mathrm{m}^{2}$, mean wind speeds range from $4.2 \mathrm{~m} / \mathrm{s}$ for $k=1$ to $7 \mathrm{~m} / \mathrm{s}$ for $k=4$. This is why mean wind speed alone is not a reliable indicator for comparing the wind energy resource for different areas or different seasons that may have different Weibull $k$ values. The Weibull $k$ values are useful in that they provide information on the nature of the frequency distribution of the wind speeds (see Figure 7). For these reasons, we have deliberately chosen to portray wind power classes and Weibull $k$ values in the assessments rather than mean wind speeds.

The maps highlight major wind energy resource areas that were determined to be generally accessible by roads or near populated areas. For example, we have not made estimates for areas that are generally unaccessible (such as rugged mountainous areas where the population is sparse or nonexistent and where roads are not present), even though such areas may have locations of high wind resource. We have purposefully highlighted major wind resource areas of 'relatively' high wind resource (in comparison to nearby areas) and have often omitted estimates for areas of 'relatively' low wind resource, in order to reduce the clutter and complexity of information on the maps and to allow one to more easily identify the better wind resource areas. Thus, if an area on a map is generally accessible and populated but no estimate is portrayed for that area, then this should be considered an area of relatively low wind resource (except on the Colombia and Venezuela maps, where estimates were made for only the Caribbean coastal and island areas). On some maps, we have also included estimates for some lower wind resource areas, either to emphasize that these areas have low wind resource (power class 1) or to indicate that these areas may have marginal-to-useful wind resource (power class 2-3) even though they have lower wind resource than the major wind resource areas identified on the maps. However, in some regions with generally low 'average' wind resource (such as Panama), even areas of marginal wind resource potential may be highlighted as major resource areas. (One should keep in mind that many areas with low-to-marginal 'average' wind resource may have useful seasonal and diurnal winds for some wind energy applications.)

We have portrayed the wind resource estimates on topographic maps to allow a user to readily associate the wind resource features with the terrain 
features. The user can usually discern the particular type of terrain feature to which the wind resource estimates in a given area apply. For example, the estimates may apply to an elongated ridge crest, a series of hilltops or broken ridges, a pass between two mountains, an elevated plateau, a valley corridor, a flat cape, etc. Moreover, the user can readily associate the locations of the wind resource areas with the locations and names of cities, towns, and prominent geographic features that are identified on the maps. (Some of the topographic and geographic features on these maps may not be clearly visible or readable; however, the aeronautical charts from which the maps were reproduced are readily available (NOAA, 1985)).

USING AND INTERPRETING THE ISLAND/COUNTRY WIND RESOURCE TABLES

The tables that accompany the island/country wind resource maps include useful information on the Weibull $k$ values and seasonal variations of the wind resource for major areas with similar resource and seasonal variations; these areas are identified on the maps with capital letters, e.g. A, B, C, etc., depending an the number of different areas. On maps with only one type of area, no letters are used. For each type of area, four indicators of the wind power are given in the tables: the annual average power, and periods of the year during which the wind power is useful (class 3 or greater), at its maximum, and at its minimum, along with the magnitude of the power during the months of maximum and minimum power. Weibull $k$ values are included for the annual average and for the months of maximum power. These Weibull $k$ values usually represent values at $10 \mathrm{~m}$ over open ocean in the vicinity of an island or coastal area, based on our analyses of the corrected ship data (Table 2). However, as discussed in previous sections, terrain influences can modify the Weibull k values. For example, sea breeze effects may increase the daytime speeds and nocturnal stability effects may reduce the speeds at night. This causes a wider spread in the frequency distribution of wind speeds, in comparison to the open ocean distribution. Thus, terrain effects generally decrease the Weibull $k$ values.

We have developed some guidelines for adjusting the corrected Weibull k values derived from the ship data to estimate Weibull $k$ values at flat coastal and inland sites. These adjustment factors, which are given in Table 4, were 
TABLE 4. Weibull k Multiplication Factors for Adjusting Weibull $k$ Values at $10 \mathrm{~m}$ Over Open Ocean to Flat Coastal and Inland Sites

\begin{tabular}{|c|c|c|c|}
\hline \multirow[b]{2}{*}{ Site Location } & \multicolumn{3}{|c|}{ Height Above Ground } \\
\hline & 10 & 25 & 50 \\
\hline $\begin{array}{l}\text { Exposed coastal point } \\
\text { or small island }\end{array}$ & 1.00 & 1.00 & 1.00 \\
\hline $\begin{array}{l}\text { Coastal site on } \\
\text { large island }\end{array}$ & 0.90 & 0.95 & 1.00 \\
\hline Inland site & 0.80 & 0.90 & 0.95 \\
\hline
\end{tabular}

determined from an analysis of Weibull $k$ data from various sites in the Caribbean and the Pacific. For well-exposed coastal points that protrude into the ocean or very small or thin islands (e.g., only a few $\mathrm{km}$ in extent) where terrain effects on the large-scale flow are insignificant, Weibull $k$ values are approximately equal to that of the open ocean. Such sites generally have little or no diurnal variation of wind speed, and there is usually little or no variation of Weibull $\mathrm{k}$ with height at these sites. For coastal sites on larger islands (more than a few $\mathrm{km}$ in extent), terrain influences such as the sea breeze reduce the $k$ values at $10 \mathrm{~m}$ by about $10 \%$. At $25 \mathrm{~m}$, the reduction is about $5 \%$. At inland sites, the $k$ values may be reduced by $20 \%$ or more, due to increased effects of terrain influences such as daytime heating, nocturnal cooling, and roughness on modifying the wind speed distribution. Inland sites in strong trade-wind areas typically have large diurnal variations in wind speed, as strong winds aloft are mixed down to surface during the daytime but are decoupled from the surface layer at night due to nocturnal stability effects.

In flow over non-flat terrain, such as over hills and ridges, the effects of the terrain on the wind speed distribution is difficult to estimate. In cases of extreme acceleration over a terrain feature, the ambient Weibull $k$ values can be reduced by as much as $40 \%$. However, in some cases, there may be little difference between the Weibull $k$ value for an elevated terrain feature and that of the ambient flow, such as a ridge crest site where the diurnal variation is small and acceleration (or deceleration) effects on the ambient flow are minimal. As a general guideline, a 10 to $20 \%$ reduction of the 
Weibull $k$ value should be suitable on the average for the majority of sites in non-flat terrain.

\section{ESTIMATING MEAN WIND SPEEDS AND EXTRAPOLATING TO DIFFERENT HEIGHTS}

Given the wind power class (or mean wind power density) at $10 \mathrm{~m}$ and the Weibull k value, we can use Figure 11 to obtain an estimate of the mean wind speed at $10 \mathrm{~m}$. Guidelines for extrapolating mean wind speeds at $10 \mathrm{~m}$ to other heights over flat terrain are given in Table 5 for two different terrain roughness characteristics. One can also extrapolate the wind power density from $10 \mathrm{~m}$ to different heights by using Table 5 to extrapolate the mean wind speed to the desired height; then given an estimate of the Weibull $k$ at the desired height, one can use Figure 11 to find the wind power density for the corresponding wind speed and Weibull k value.

TABLE 5. Wind Speed Multiplication Factors for Extrapolating Mean Wind Speeds at $10 \mathrm{~m}$ to Other Heights Over Flat Terrain

Roughness

Characteristic
(a)

$10 \quad 15$
Height Above Ground (m)

Smooth surface

(ocean, sand)

$1.00 \quad 1.04 \quad 1.07$

1.10

1.12

1.13

1.15

1.16

1.17

Grass or

low scrubs

$\begin{array}{lllllllll}1.00 & 1.06 & 1.10 & 1.14 & 1.17 & 1.19 & 1.21 & 1.23 & 1.25\end{array}$

(a) Roughness characteristic in the directions from which the prevailing powerproducing winds occur.

\section{ESTIMATING PREVAILING DIRECTIONS OF THE POWER-PRODUCING WINDS}

Information on the prevailing directions of the large-scale power producing winds over the Caribbean region is given, for each month, in an appendix following the island/country maps. The prevailing directions may be quite variable over areas where two different flow features may be prevalent, such as transition areas between easterlies and westerlies, or over areas with very limited data. Annual averages of the prevailing directions of power-producing winds can be misleading, and, for this reason, an annual average map has been 
omitted. Although local effects on the large-scale wind flow may cause some variation locally in the directions of the power-producing winds, the information in the appendix should be adequate, in combination with the island/country wind resource maps and tables, for the initial assessment needs of most users. 
ISLAND/COUNTRY MAPS AND TABLES 
GRENADA

\begin{tabular}{lllll}
\hline Area & $\begin{array}{c}\text { Annual } \\
\text { Average }\end{array}$ & $\begin{array}{l}\text { Useful } \\
\text { Power }\end{array}$ & $\begin{array}{c}\text { Maximum } \\
\text { Power }\end{array}$ & $\begin{array}{c}\text { Minimum } \\
\text { Power }\end{array}$ \\
\hline A & $P \quad 3-6$ & All year & Jan-Jun & Sep-Nov \\
& $k 3.2-3.4$ & & P 4-6 & P 2-4 \\
& & & $k 3.6-4.6$
\end{tabular}




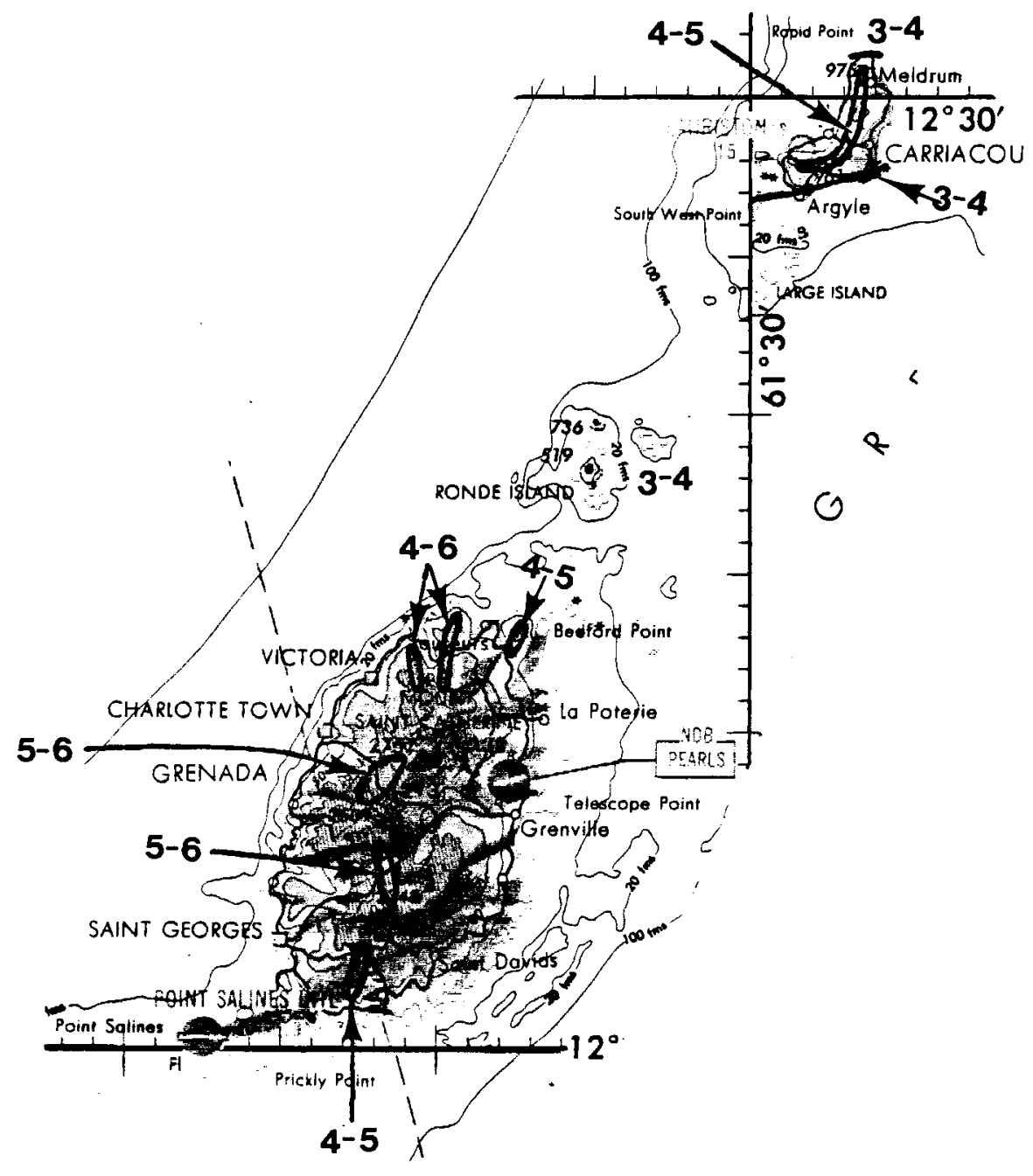


SAINT VINCENT AND THE GRENADINES

\begin{tabular}{lllll}
\hline Area & $\begin{array}{c}\text { Annual } \\
\text { Average }\end{array}$ & $\begin{array}{l}\text { Usefu1 } \\
\text { Power }\end{array}$ & $\begin{array}{c}\text { Maximum } \\
\text { Power }\end{array}$ & $\begin{array}{c}\text { Minimum } \\
\text { Power }\end{array}$ \\
\hline A & P $3-6$ & All year & Jan-Jul & Aug-Nov \\
& $\mathrm{k} 3.2-3.4$ & & P 4-6 & P 2-4 \\
& & & k 3.6-4.6
\end{tabular}




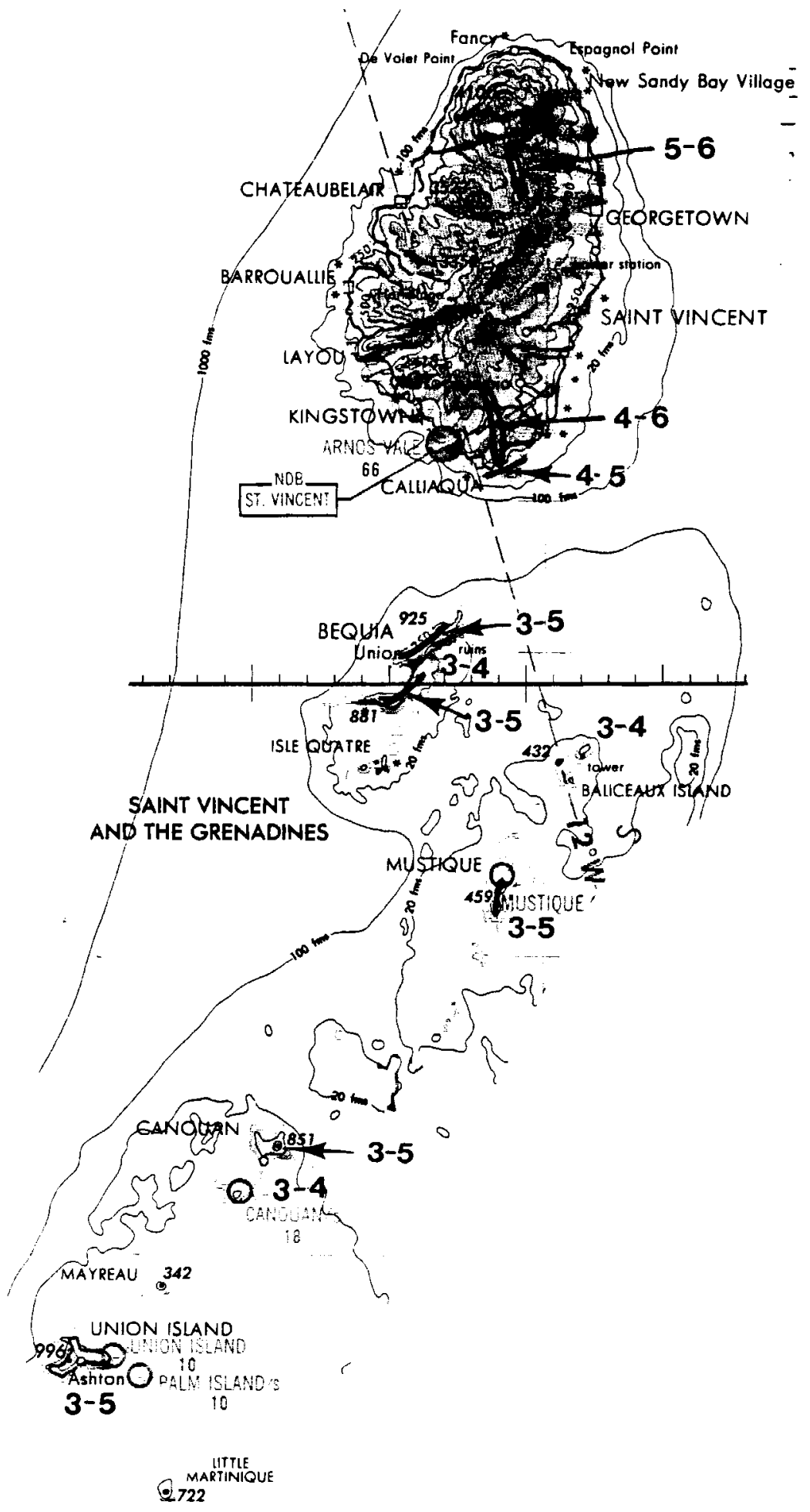


BARBADOS

\begin{tabular}{|c|c|c|c|c|}
\hline Area & $\begin{array}{r}\text { Annual } \\
\text { Average }\end{array}$ & $\begin{array}{l}\text { Useful } \\
\text { Power }\end{array}$ & $\begin{array}{l}\text { Maximum } \\
\text { Power }\end{array}$ & $\begin{array}{l}\text { Minimum } \\
\text { Power }\end{array}$ \\
\hline & $P \quad 3-6$ & All year & Jun-Ju1 & Sep-Nov \\
\hline & k $3.2-3.4$ & & $P \quad 4-6$ & P $\quad 2-4$ \\
\hline & & & $k \quad 4.0-4.6$ & \\
\hline
\end{tabular}




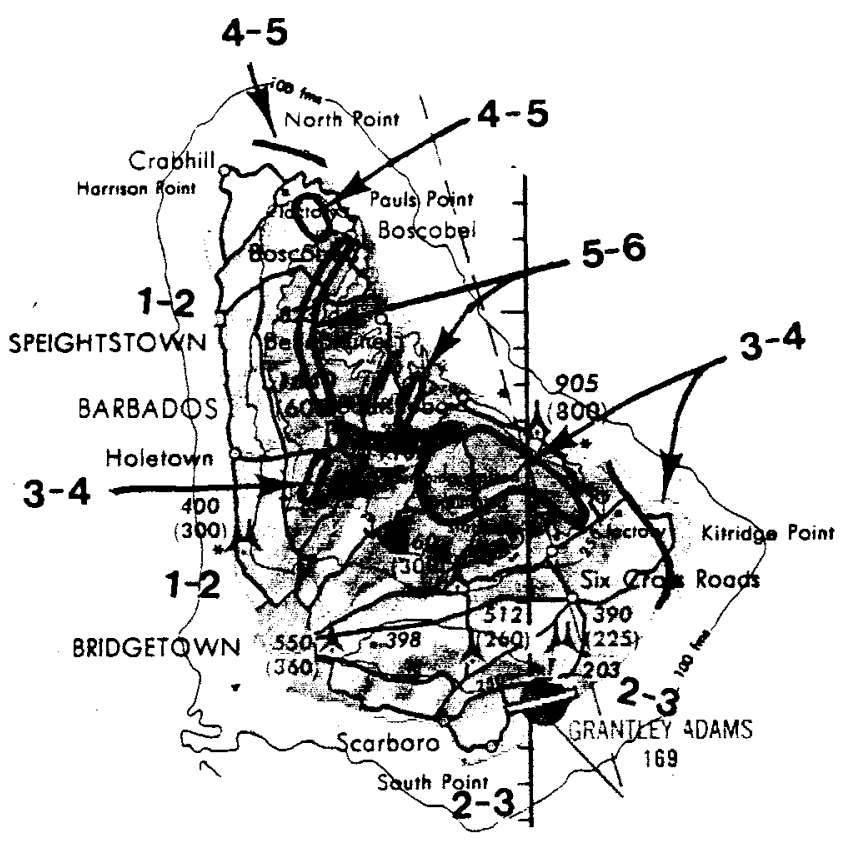


SAINT LUCIA

\begin{tabular}{lllll}
\hline Area & $\begin{array}{c}\text { Annual } \\
\text { Average }\end{array}$ & $\begin{array}{l}\text { Useful } \\
\text { Power }\end{array}$ & $\begin{array}{c}\text { Maximum } \\
\text { Power }\end{array}$ & $\begin{array}{c}\text { Minimum } \\
\text { Power }\end{array}$ \\
\hline & P $3-6$ & Al1 year & Jun-Ju1 & Sep-Nov \\
$k \quad 3.2-3.4$ & & P 5-6 & P 2-4 \\
& & k 4.0-4.6 &
\end{tabular}




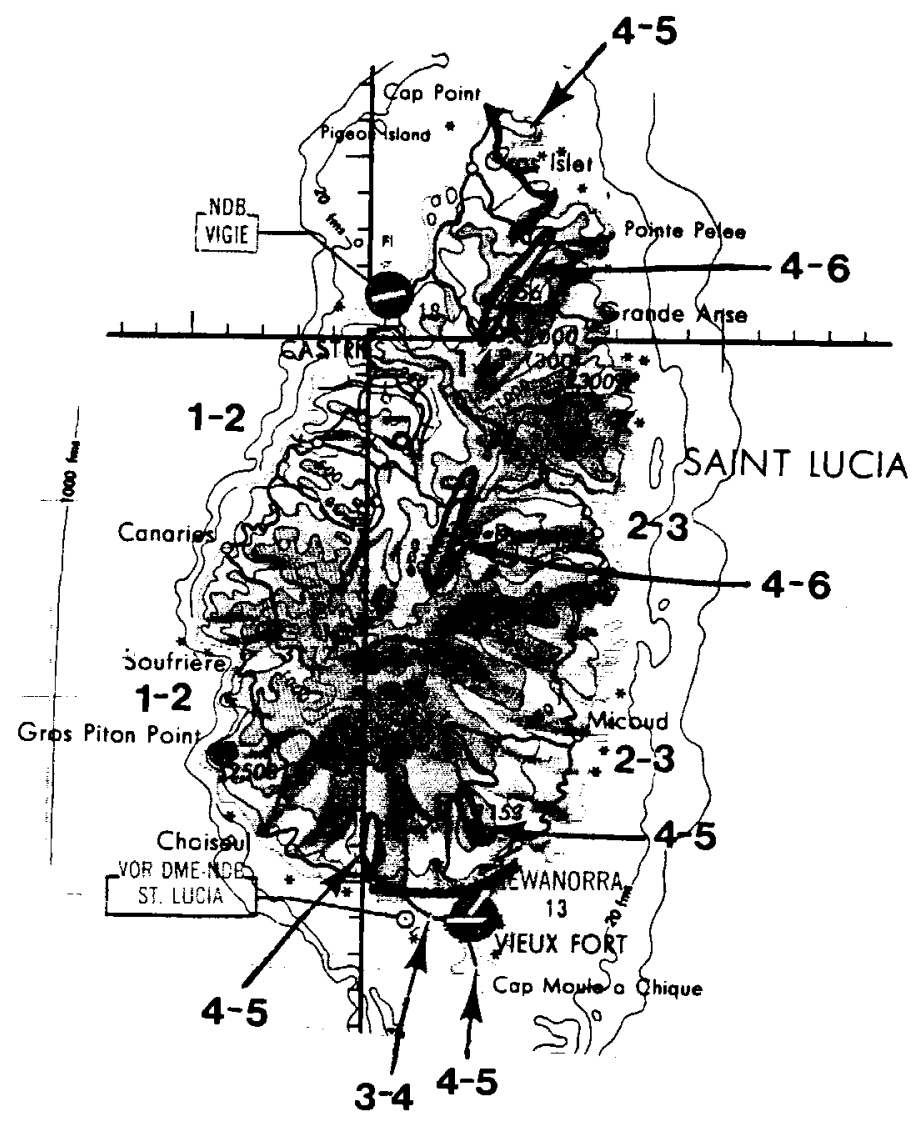




\section{MARTINIQUE}

\begin{tabular}{|c|c|c|c|c|c|}
\hline Area & & $\begin{array}{l}\text { Annual } \\
\text { verage }\end{array}$ & $\begin{array}{l}\text { Useful } \\
\text { Power }\end{array}$ & $\begin{array}{l}\text { Maximum } \\
\text { Power }\end{array}$ & $\begin{array}{l}\text { Minimum } \\
\text { Power }\end{array}$ \\
\hline \multirow[t]{3}{*}{$A$} & $P$ & $5-6$ & All year & Jun-Jul & Sep-Nov \\
\hline & k & $3.2-3.4$ & & P $\quad 6-7$ & $P \quad 3-4$ \\
\hline & & & & k $\quad 4.0-5.0$ & \\
\hline \multirow[t]{3}{*}{ B } & $P$ & $3-5$ & All year & Jun-Jul & Sep-Nov \\
\hline & $k$ & $3.2-3.4$ & & $P \quad 4-6$ & $P \quad 2-3$ \\
\hline & & & & k $4.0-5.0$ & \\
\hline
\end{tabular}




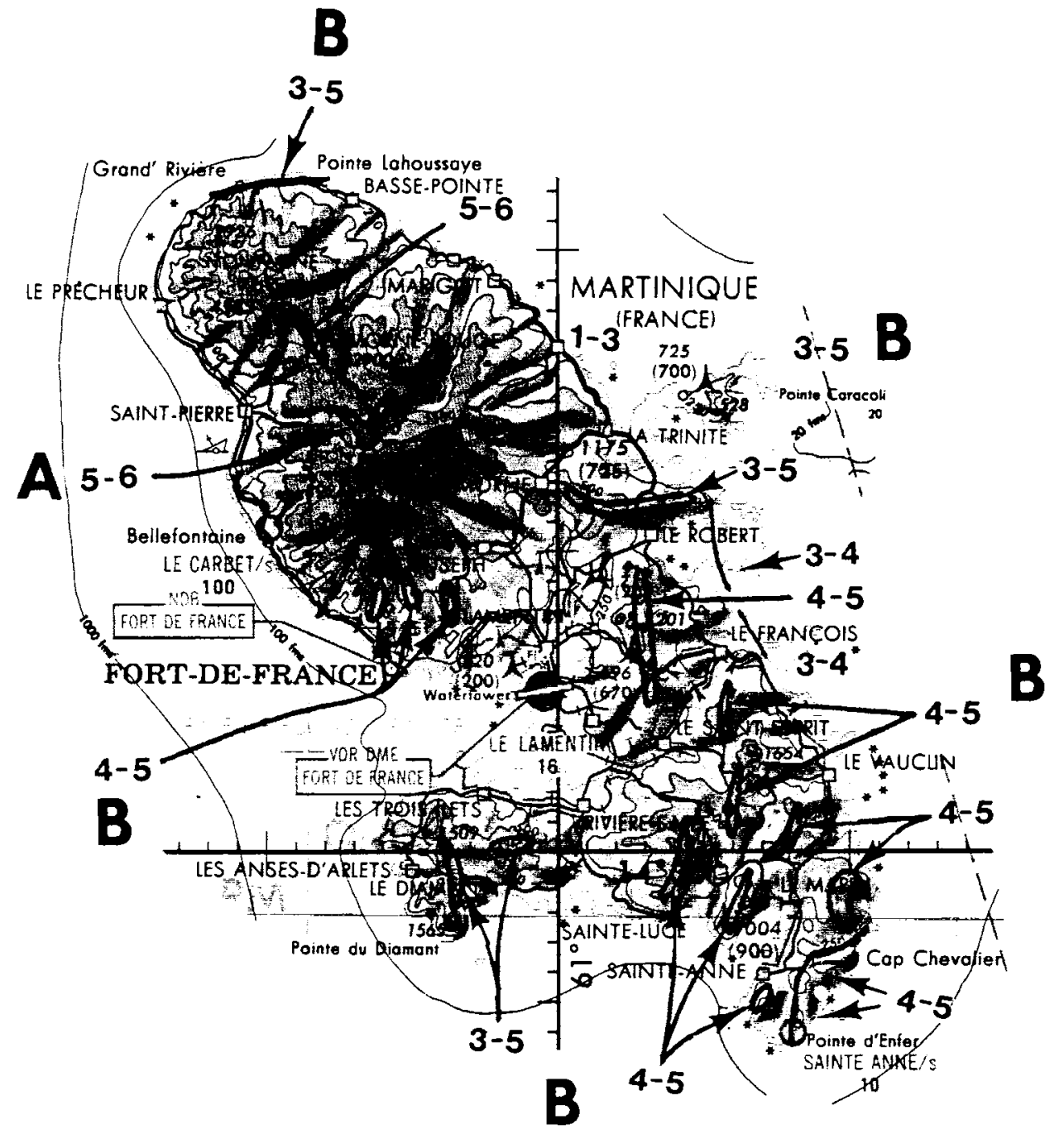


DOMINICA

\begin{tabular}{lllll}
\hline Area & $\begin{array}{l}\text { Annual } \\
\text { Average }\end{array}$ & $\begin{array}{l}\text { Useful } \\
\text { Power }\end{array}$ & $\begin{array}{l}\text { Maximum } \\
\text { Power }\end{array}$ & $\begin{array}{c}\text { Minimum } \\
\text { Power }\end{array}$ \\
\hline A & P $3-6$ & All year & Jun-Jul & Sep-Nov \\
& $k 3.2-3.4$ & & P $4-7$ & P 2-4 \\
& k $340-5.0$ &
\end{tabular}




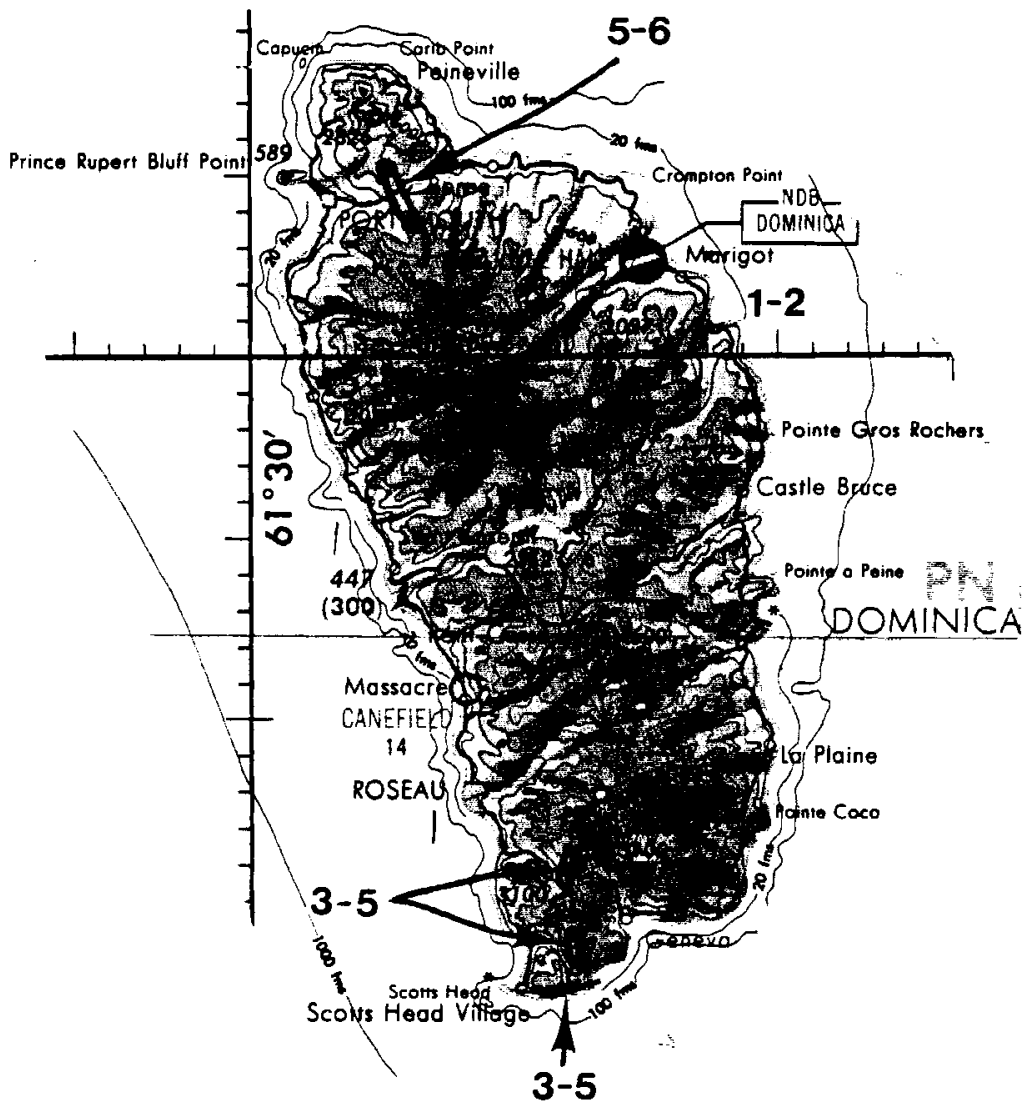




\section{GUADELOUPE}

\begin{tabular}{|c|c|c|c|c|c|}
\hline Area & & $\begin{array}{l}\text { Annual } \\
\text { verage }\end{array}$ & $\begin{array}{l}\text { Useful } \\
\text { Power }\end{array}$ & $\begin{array}{l}\text { Maximum } \\
\text { Power }\end{array}$ & $\begin{array}{l}\text { Minimum } \\
\text { Power }\end{array}$ \\
\hline \multirow[t]{3}{*}{ A } & $P$ & $4-6$ & All year & Jun-Jul & Sep-Nov \\
\hline & & $3.2-3.4$ & & P 5-7 & P 2-4 \\
\hline & & & & $k \quad 4.0-5.0$ & \\
\hline \multirow[t]{3}{*}{ B } & $P$ & $3-5$ & All year & Jun-Jul & Sep-Nov \\
\hline & & $3.2-3.4$ & & $P \quad 4-6$ & $P \quad 2-3$ \\
\hline & & & & $k \quad 4.0-5.0$ & \\
\hline
\end{tabular}




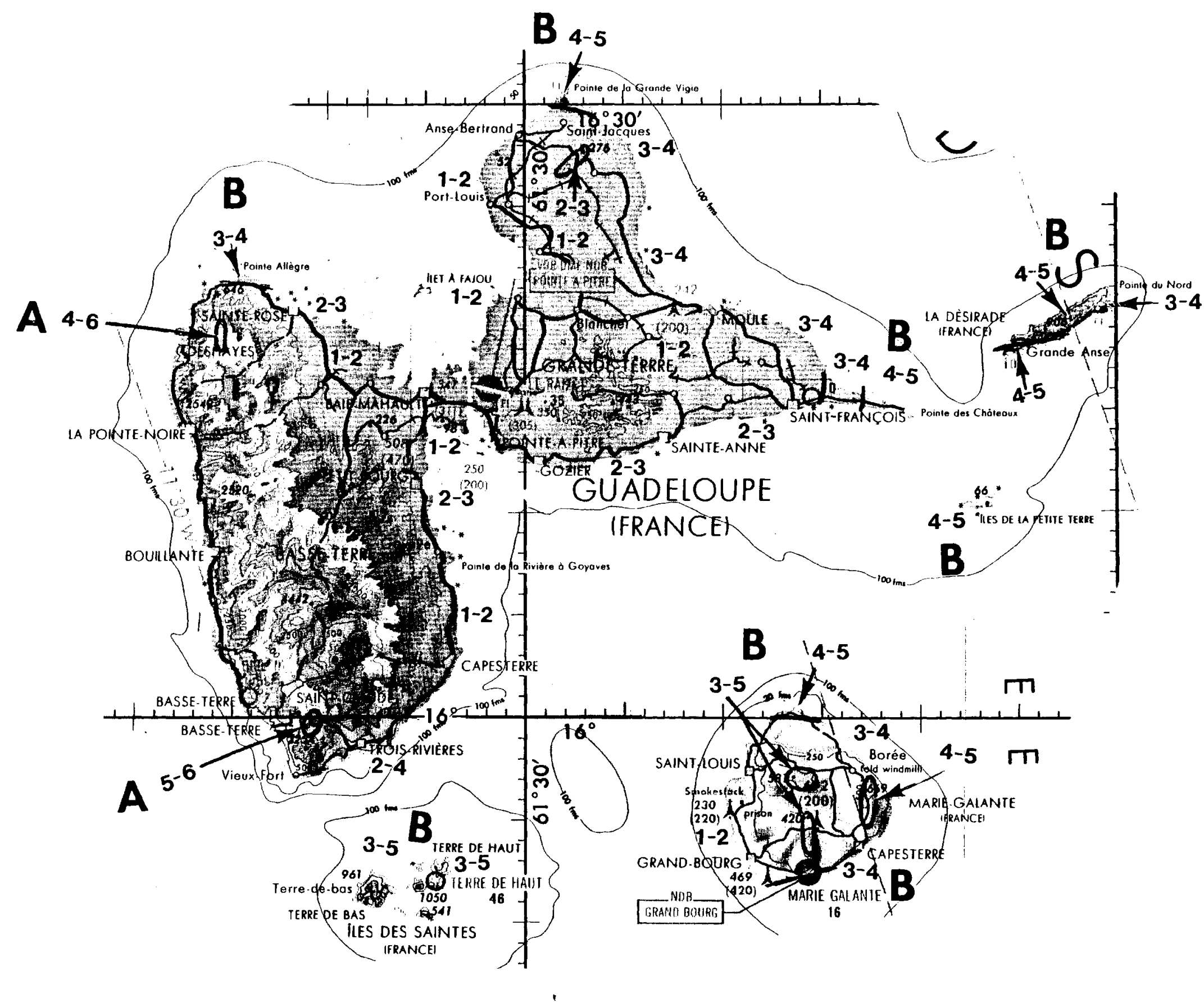


ANTIGUA, BARBUDA, AND MONTSERRAT

\begin{tabular}{|c|c|c|c|c|c|}
\hline Area & & $\begin{array}{l}\text { Annual } \\
\text { verage }\end{array}$ & $\begin{array}{l}\text { Useful } \\
\text { Power }\end{array}$ & $\begin{array}{l}\text { Maximum } \\
\text { Power }\end{array}$ & $\begin{array}{l}\text { Minimum } \\
\text { Power }\end{array}$ \\
\hline \multirow[t]{3}{*}{$A$} & $P$ & $5-7$ & A11 year & Jun-Aug & Sep-Nov \\
\hline & $k$ & $3.0-3.4$ & & $P \quad 6-7$ & P $3-4$ \\
\hline & & & & $k \quad 4.0-5.0$ & \\
\hline \multirow[t]{3}{*}{ B } & $P$ & $3-5$ & A11 year & Jun-Aug & Sep-Nor \\
\hline & \multirow[t]{2}{*}{$k$} & $3.0-3.4$ & & $P \quad 4-6$ & \multirow[t]{2}{*}{$2-3$} \\
\hline & & & & $k \quad 4.0-5.0$ & \\
\hline
\end{tabular}




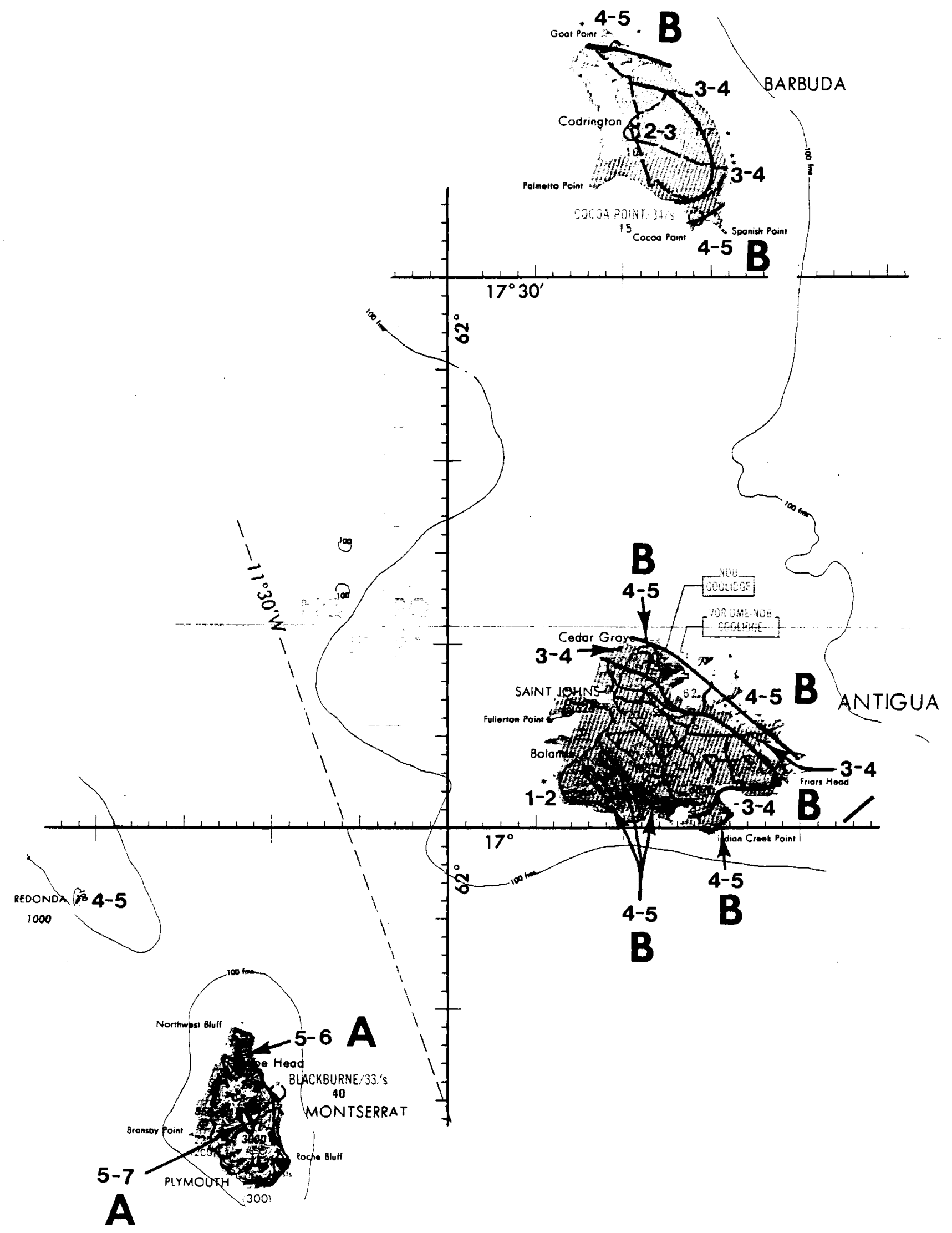


NEVIS, SABA, SAINT CHRISTOPHER, SINT EUSTATIUS

\begin{tabular}{lllll}
\hline Area & $\begin{array}{c}\text { Annual } \\
\text { Average }\end{array}$ & $\begin{array}{l}\text { Useful } \\
\text { Power }\end{array}$ & $\begin{array}{c}\text { Maximum } \\
\text { Power }\end{array}$ & $\begin{array}{c}\text { Minimum } \\
\text { Power }\end{array}$ \\
\hline A11 & P $3-6$ & A11 year & Jun-Aug & Sep-Nov \\
& $k 3.0-3.4$ & & P 4-7 & P 2-4 \\
& & k 4.0-5.0 &
\end{tabular}




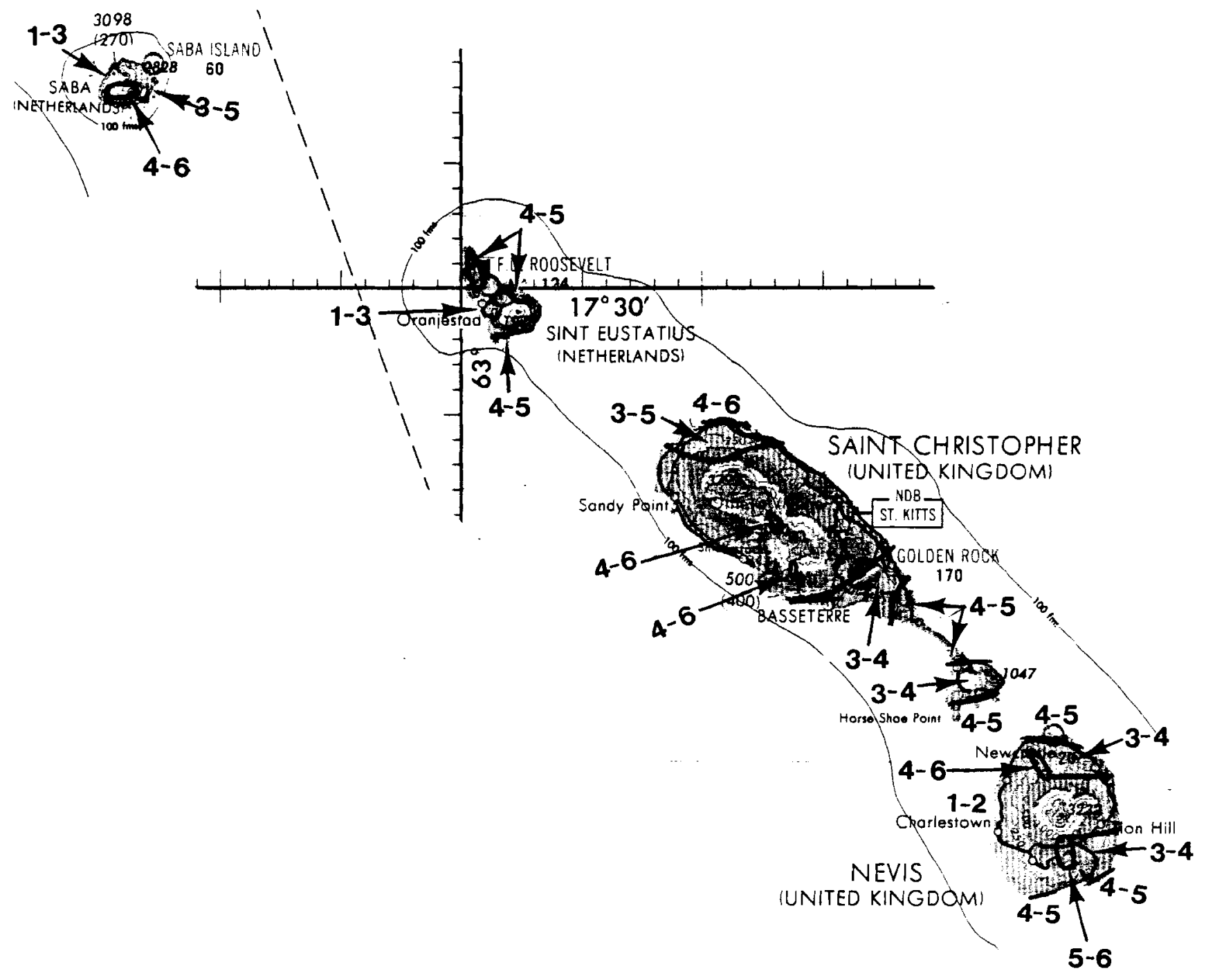


ANGUILLA, SAINT MARTIN, AND SAINT BARTHELEMY

\begin{tabular}{lllll}
\hline Area & $\begin{array}{c}\text { Annual } \\
\text { Average }\end{array}$ & $\begin{array}{l}\text { Useful } \\
\text { Power }\end{array}$ & $\begin{array}{c}\text { Maximum } \\
\text { Power }\end{array}$ & $\begin{array}{c}\text { Minimum } \\
\text { Power }\end{array}$ \\
\hline A & P $4-6$ & All year & Jun-Aug & Sep-Nov \\
& $k \quad 3.0-3.4$ & & $P 5-7$ & $P$ 2-3 \\
& & $k 4.0-4.6$ & \\
& & & \\
& & Dec-Mar \\
& & P 5-6 \\
& & $k 2.8-3.4$
\end{tabular}




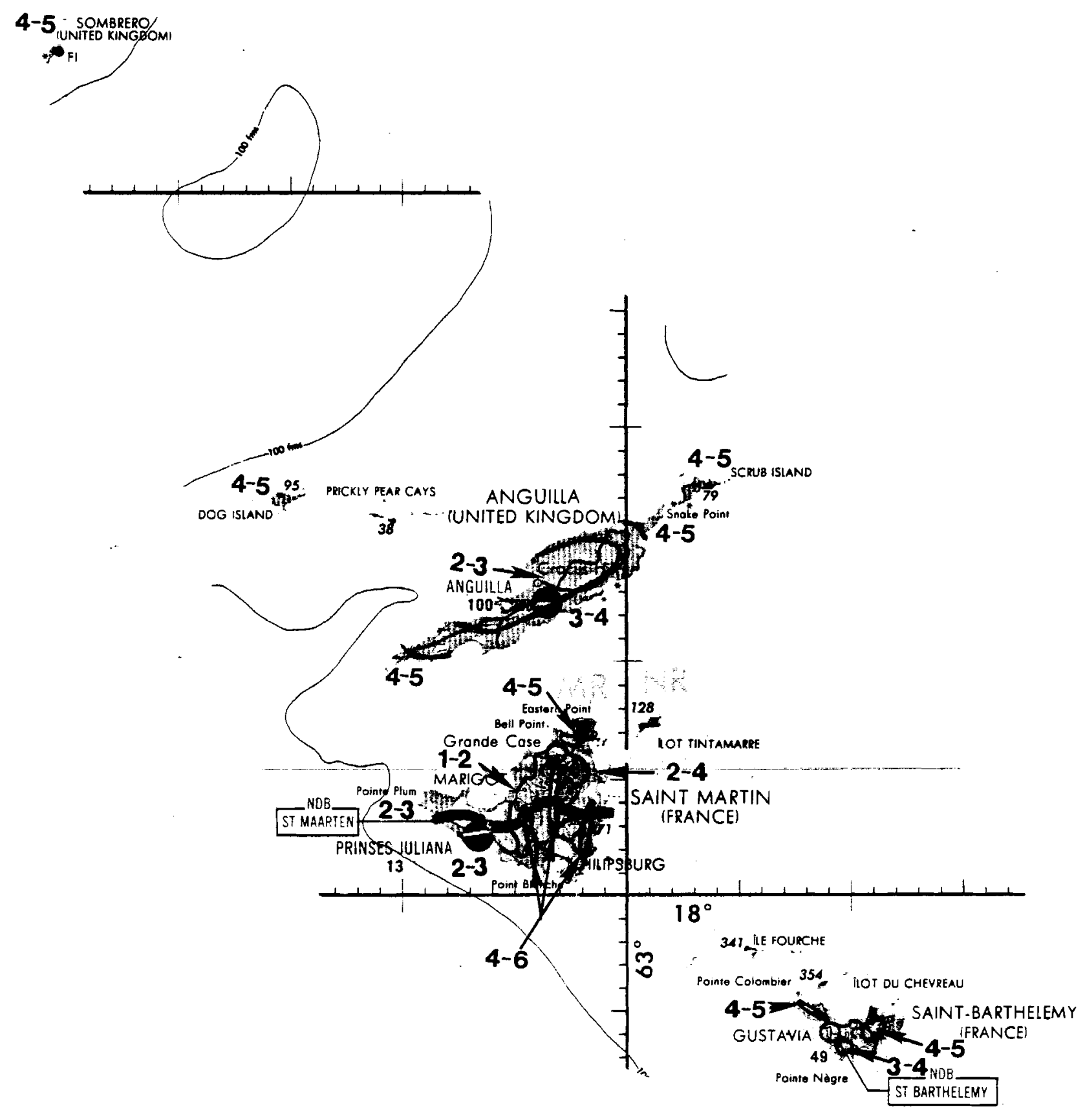


VIRGIN ISLANDS

\begin{tabular}{|c|c|c|c|c|c|}
\hline Area & & $\begin{array}{l}\text { Annual } \\
\text { verage }\end{array}$ & $\begin{array}{l}\text { Useful } \\
\text { Power }\end{array}$ & $\begin{array}{l}\text { Maximum } \\
\text { Power }\end{array}$ & $\begin{array}{l}\text { Minimum } \\
\text { Power }\end{array}$ \\
\hline \multirow[t]{6}{*}{ All } & & $3-5$ & A11 except & Jun-Aug & Sep-Nov \\
\hline & & $3.0-3.4$ & Oct & P $4-6$ & P $2-3$ \\
\hline & & & & k $4.0-4.6$ & \\
\hline & & & & Dec-Mar & \\
\hline & & & & $P \quad 4-6$ & \\
\hline & & & & k 2.8-3.4 & \\
\hline
\end{tabular}



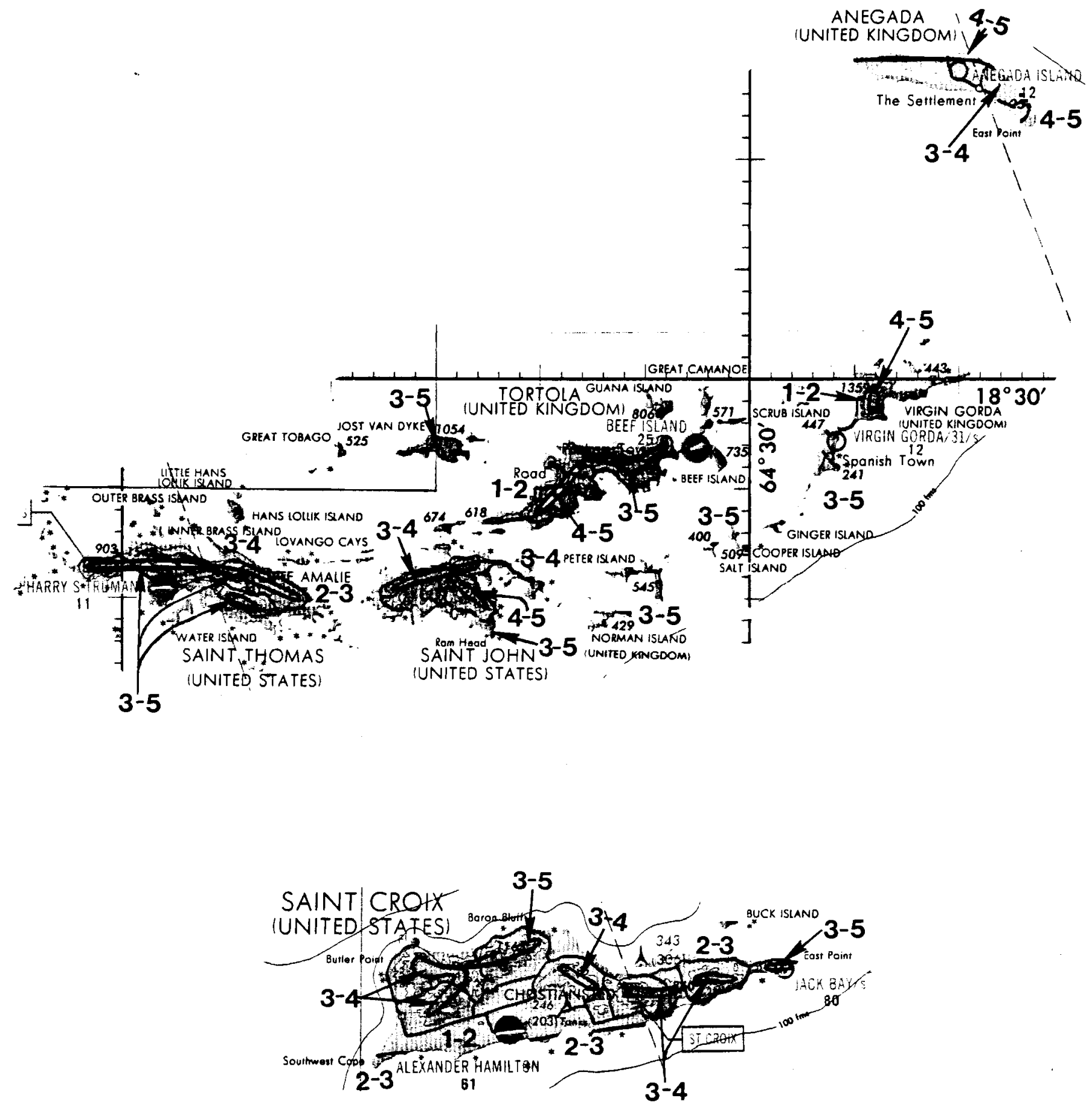
PUERTO RICO

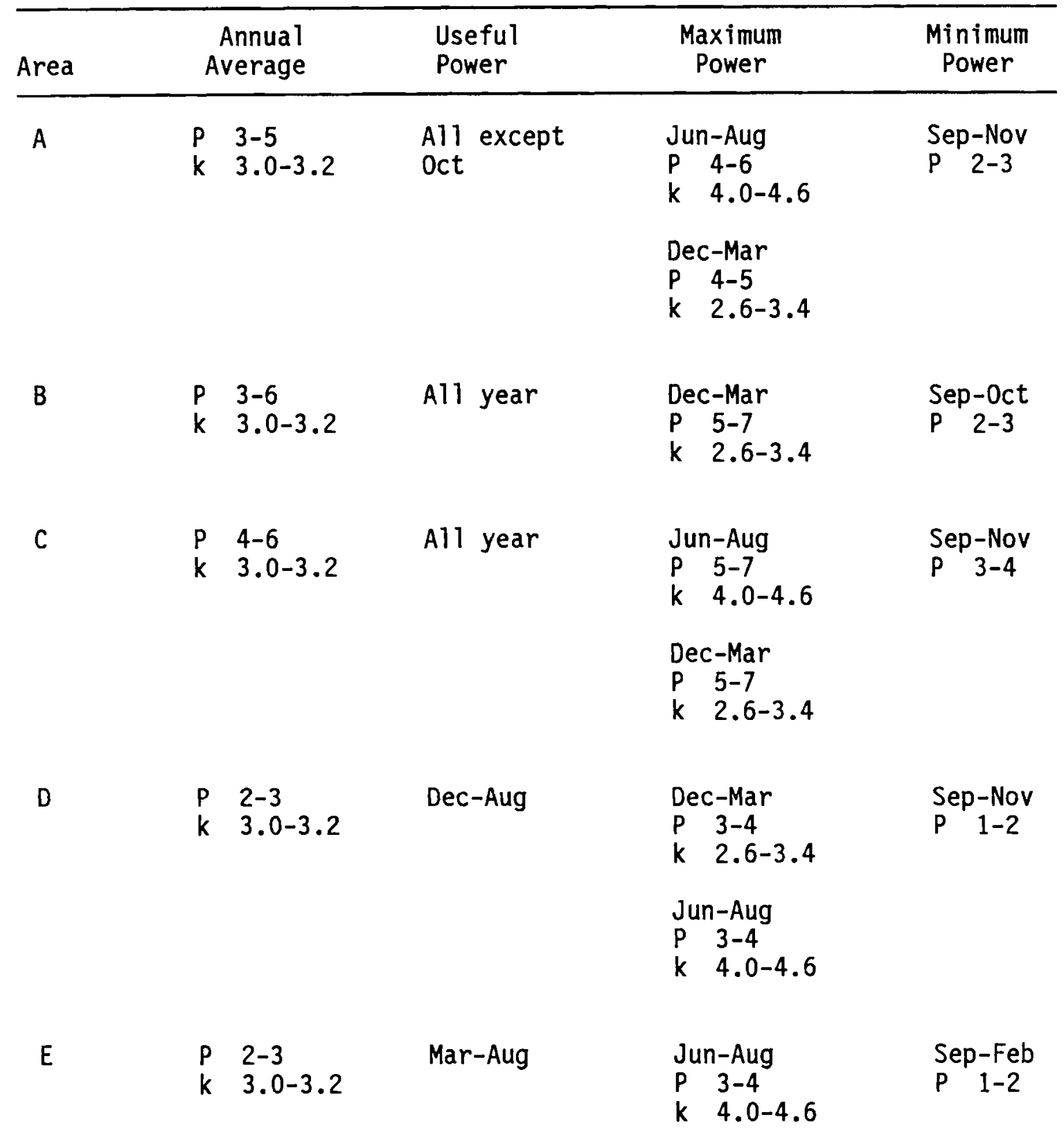




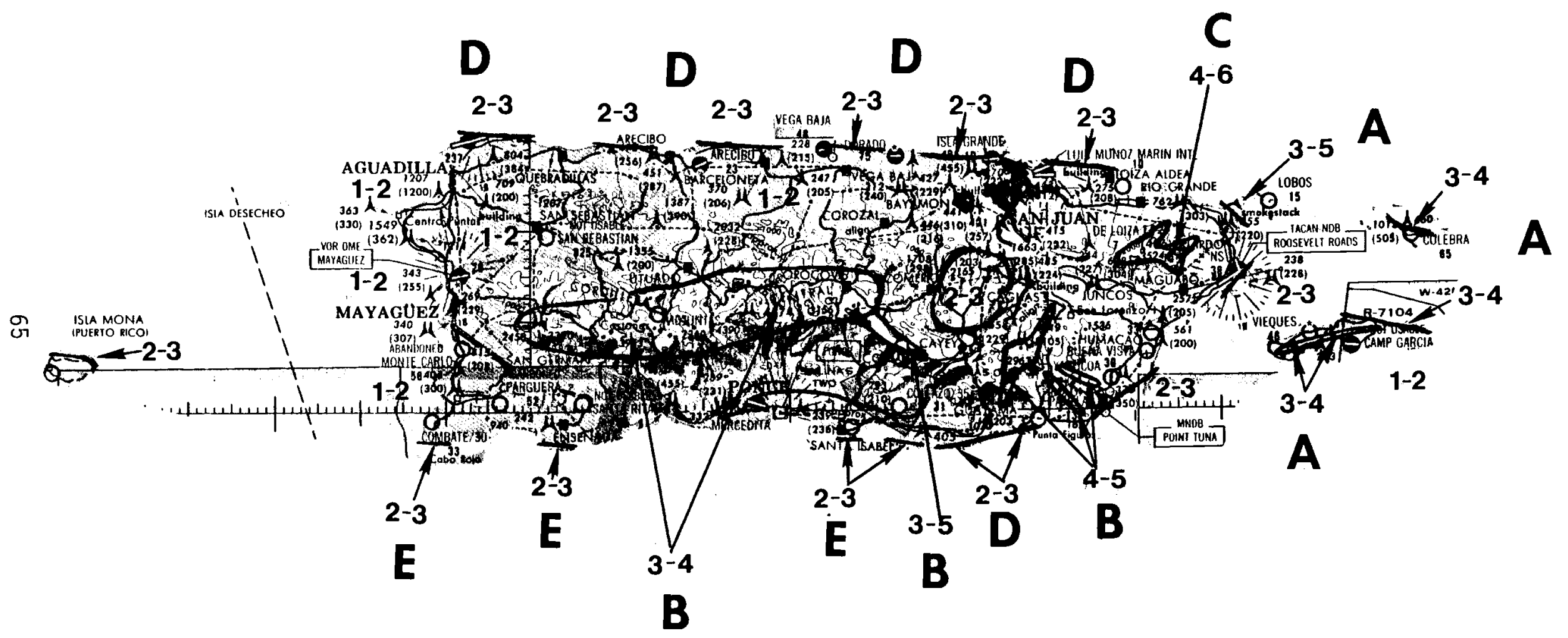


DOMINICAN REPUBLIC

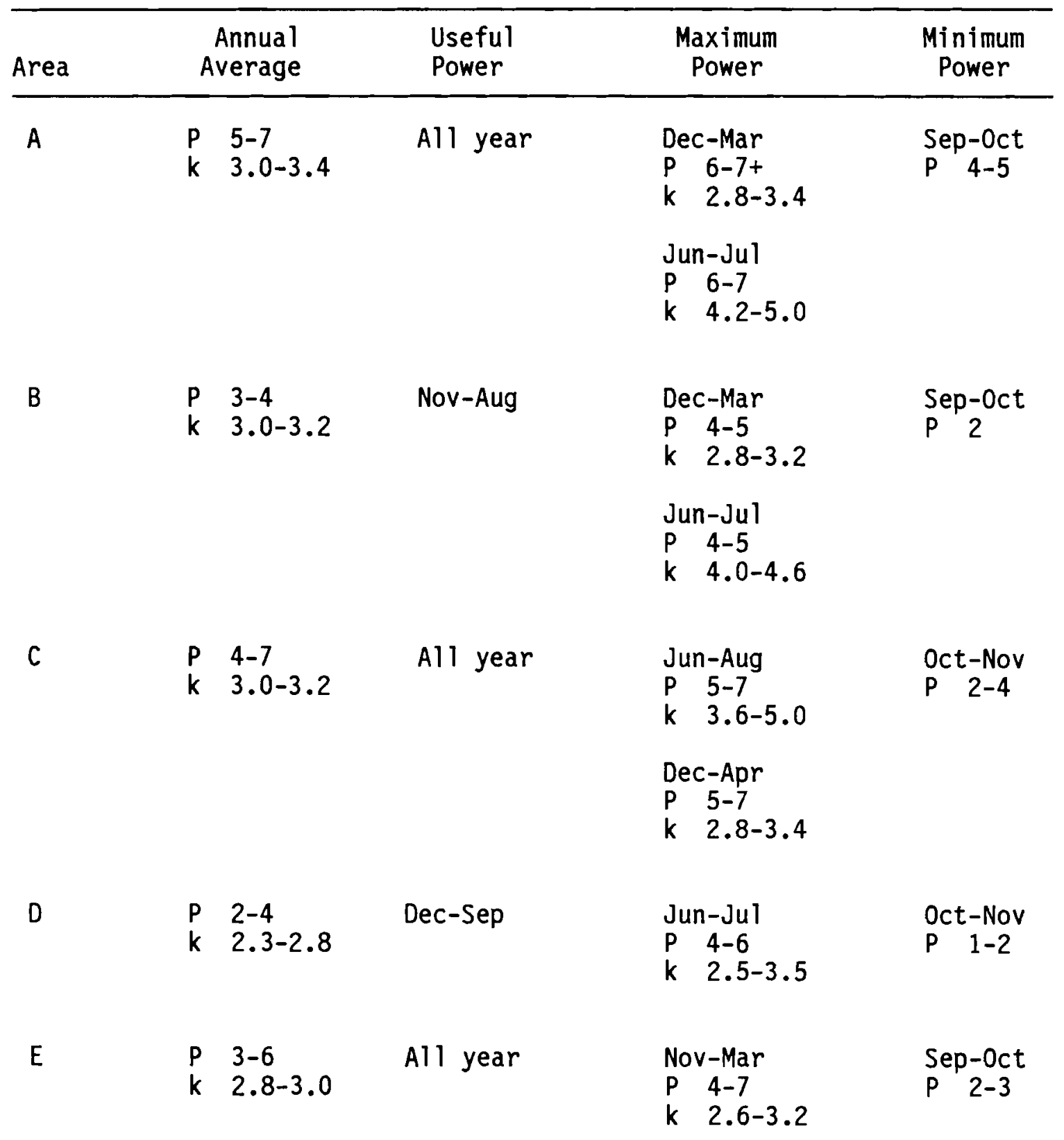




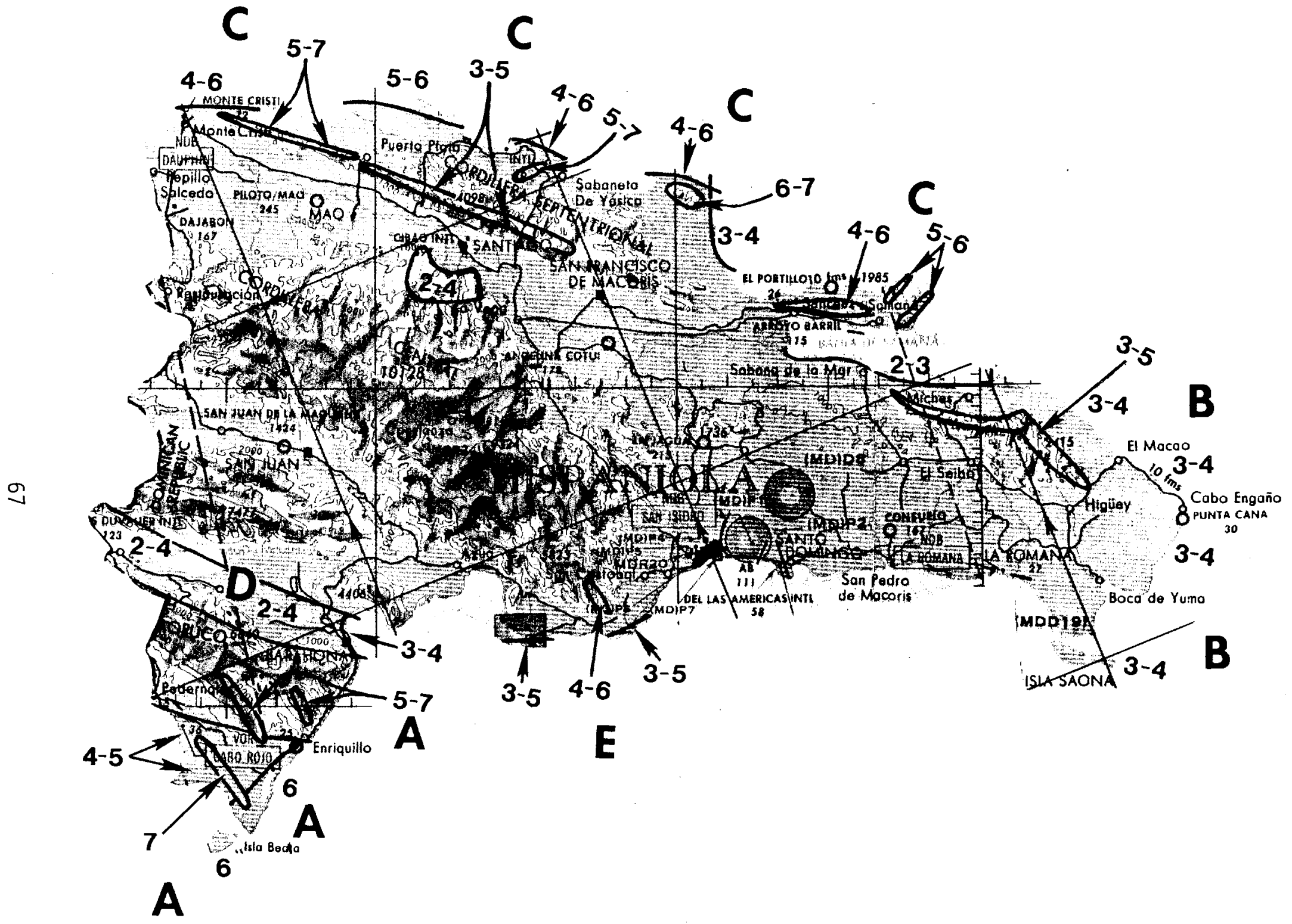


HAITI

\begin{tabular}{|c|c|c|c|c|c|}
\hline Area & & $\begin{array}{l}\text { Annual } \\
\text { verage }\end{array}$ & $\begin{array}{l}\text { Useful } \\
\text { Power }\end{array}$ & $\begin{array}{l}\text { Maximum } \\
\text { Power }\end{array}$ & $\begin{array}{l}\text { Minimum } \\
\text { Power }\end{array}$ \\
\hline \multirow[t]{6}{*}{$A$} & $P$ & $4-7$ & All year & Jul-Aug & oct \\
\hline & $k$ & $2.8-3.0$ & & P 5-7 & $P \quad 2-3$ \\
\hline & & & & $k \quad 4.0-5.0$ & \\
\hline & & & & Dec-Apr & \\
\hline & & & & P 5-7 & \\
\hline & & & & $k \quad 2.6-3.2$ & \\
\hline \multirow[t]{3}{*}{ B } & $P$ & $3-5$ & Nov-May, & Nov-Feb & Sep-0ct \\
\hline & $k$ & $2.0-2.4$ & Jul-Aug & $P \quad 4-6$ & P 1-2 \\
\hline & & & & k 2.4-2.8 & \\
\hline \multirow[t]{3}{*}{$\mathrm{C}$} & $P$ & $2-4$ & Nov-Mar & Dec-Jan & Aug-0ct \\
\hline & $k$ & $2.0-2.4$ & & $P \quad 3-5$ & $P \quad 1-2$ \\
\hline & & & & k $2.0-2.4$ & \\
\hline \multirow[t]{3}{*}{$D$} & $P$ & $3-5$ & Jan-Sep & Jun-Jul & Nov-Dec \\
\hline & $k$ & $2.6-3.0$ & & $P \quad 5-6$ & $1-2$ \\
\hline & & & & k $3.6-4.6$ & \\
\hline \multirow[t]{3}{*}{$E$} & $P$ & $2-3$ & Feb-Sep & Jun-Jul & Oct-Jan \\
\hline & & $2.3-2.8$ & & $P \quad 4-5$ & P $1-2$ \\
\hline & & & & k 2.5-3.5 & \\
\hline
\end{tabular}




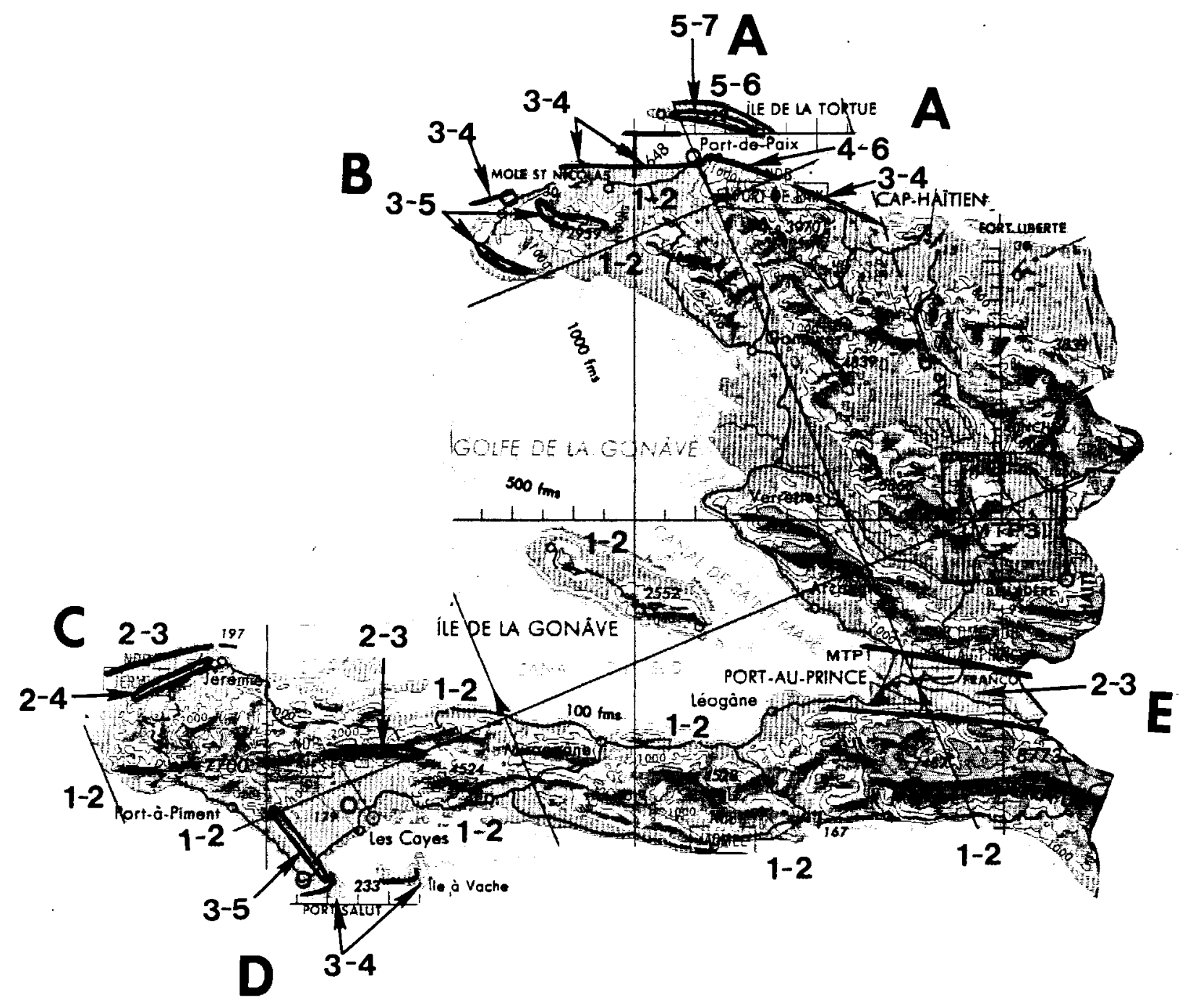


JAMAICA

\begin{tabular}{|c|c|c|c|c|c|}
\hline Area & & $\begin{array}{l}\text { Annual } \\
\text { verage }\end{array}$ & $\begin{array}{l}\text { Useful } \\
\text { Power }\end{array}$ & $\begin{array}{l}\text { Maximum } \\
\text { Power }\end{array}$ & $\begin{array}{l}\text { Minimum } \\
\text { Power }\end{array}$ \\
\hline \multirow[t]{3}{*}{$A$} & $P$ & $3-4$ & Nov-Aug & Dec-Jan & Aug-0ct \\
\hline & $k$ & $2.4-2.6$ & & $P \quad 4-5$ & P 2 \\
\hline & & & & $k \quad 2.4-2.6$ & \\
\hline \multirow[t]{3}{*}{ B } & $\mathrm{P}$ & $3-5$ & Dec-Aug & Jun-Jul & Sep-Nov \\
\hline & k & $2.5-2.8$ & & $P \quad 5-6$ & $P \quad 1-2$ \\
\hline & & & & k $\quad 3.0-3.8$ & \\
\hline \multirow[t]{3}{*}{ C } & $\mathbf{P}$ & $2-4$ & Nov-Jul & Nov-Dec & Aug-Oct \\
\hline & k & $1.8-2.2$ & & $P \quad 4-5$ & P $1-2$ \\
\hline & & & & $k \quad 2.4-2.6$ & \\
\hline
\end{tabular}




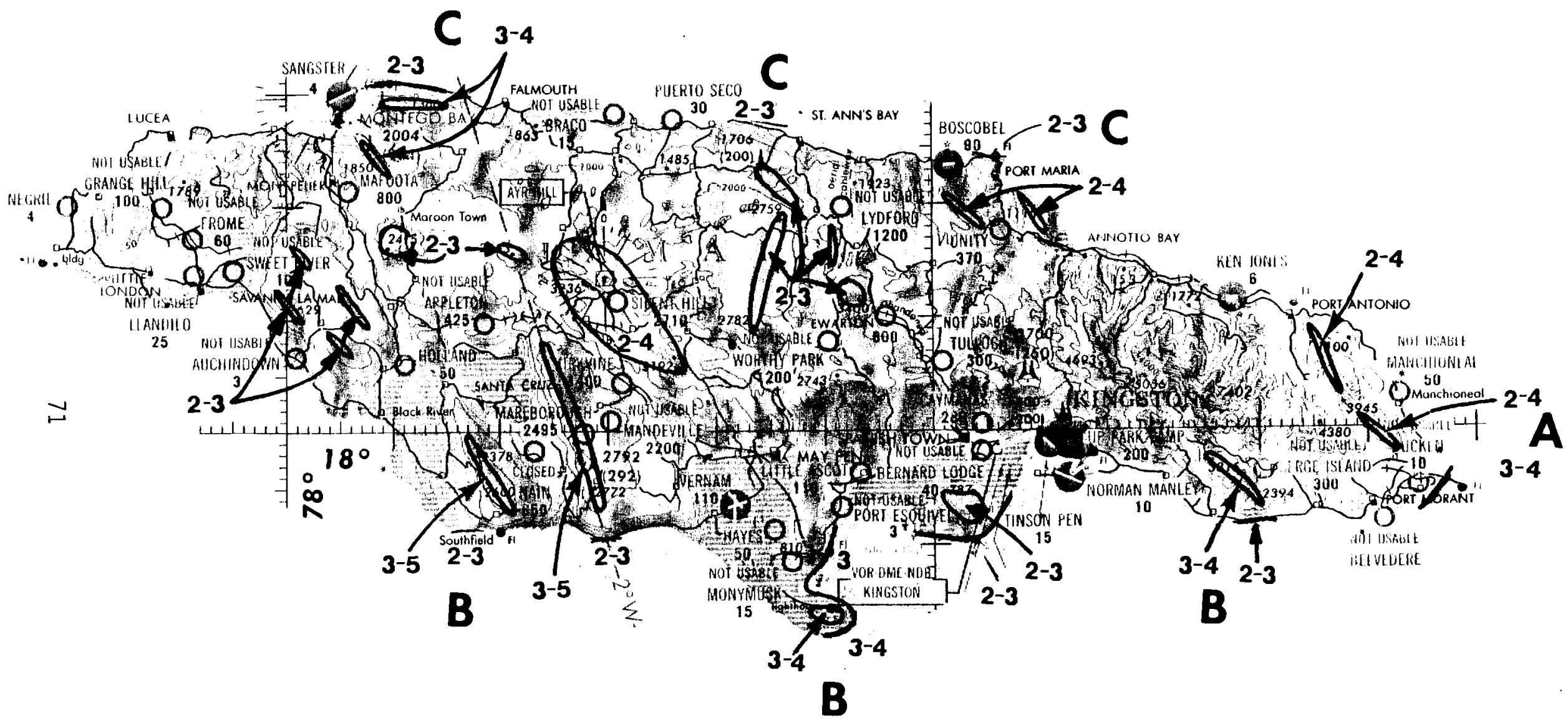




\section{CAYMAN ISLANDS}

\begin{tabular}{lllll}
\hline Area & $\begin{array}{c}\text { Annual } \\
\text { Average }\end{array}$ & $\begin{array}{l}\text { Useful } \\
\text { Power }\end{array}$ & $\begin{array}{c}\text { Maximum } \\
\text { Power }\end{array}$ & $\begin{array}{c}\text { Minimum } \\
\text { Power }\end{array}$ \\
\hline A & P $3-4$ & Oct-Jun & Nov-Jan & Apr-0ct \\
& $k 2.4-2.5$ & & $P$ 5-6 & P 2-3 \\
& & & $k 2.6-3.0$ &
\end{tabular}



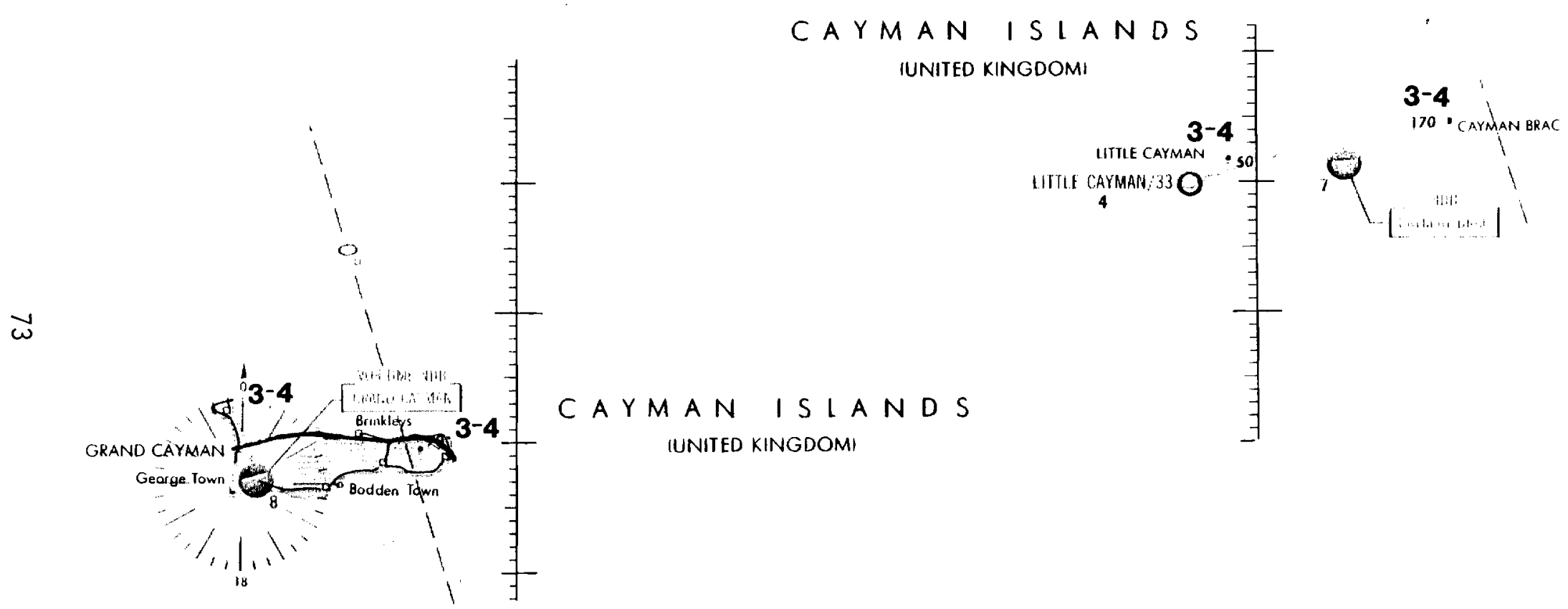


\section{CUBA}

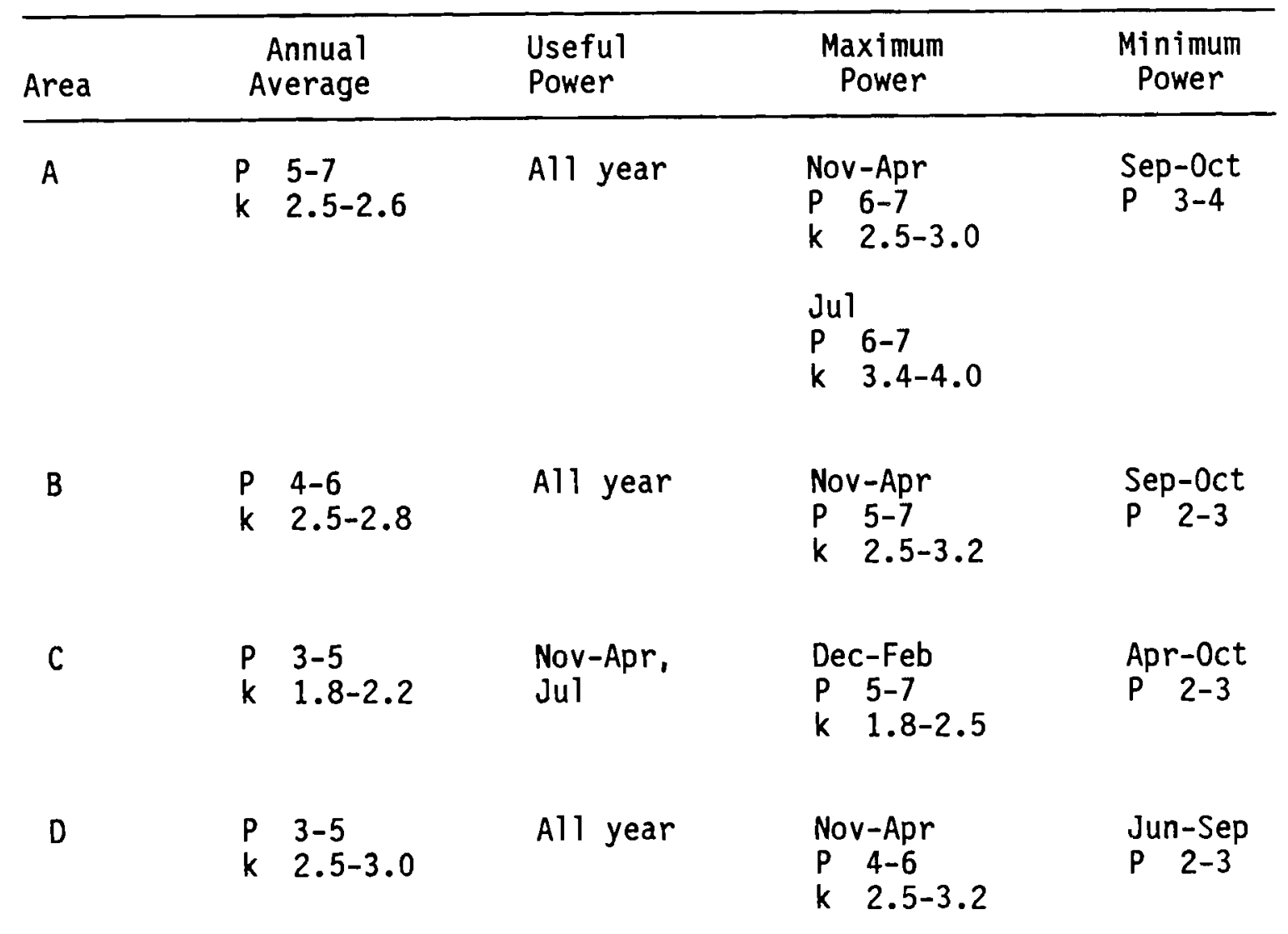




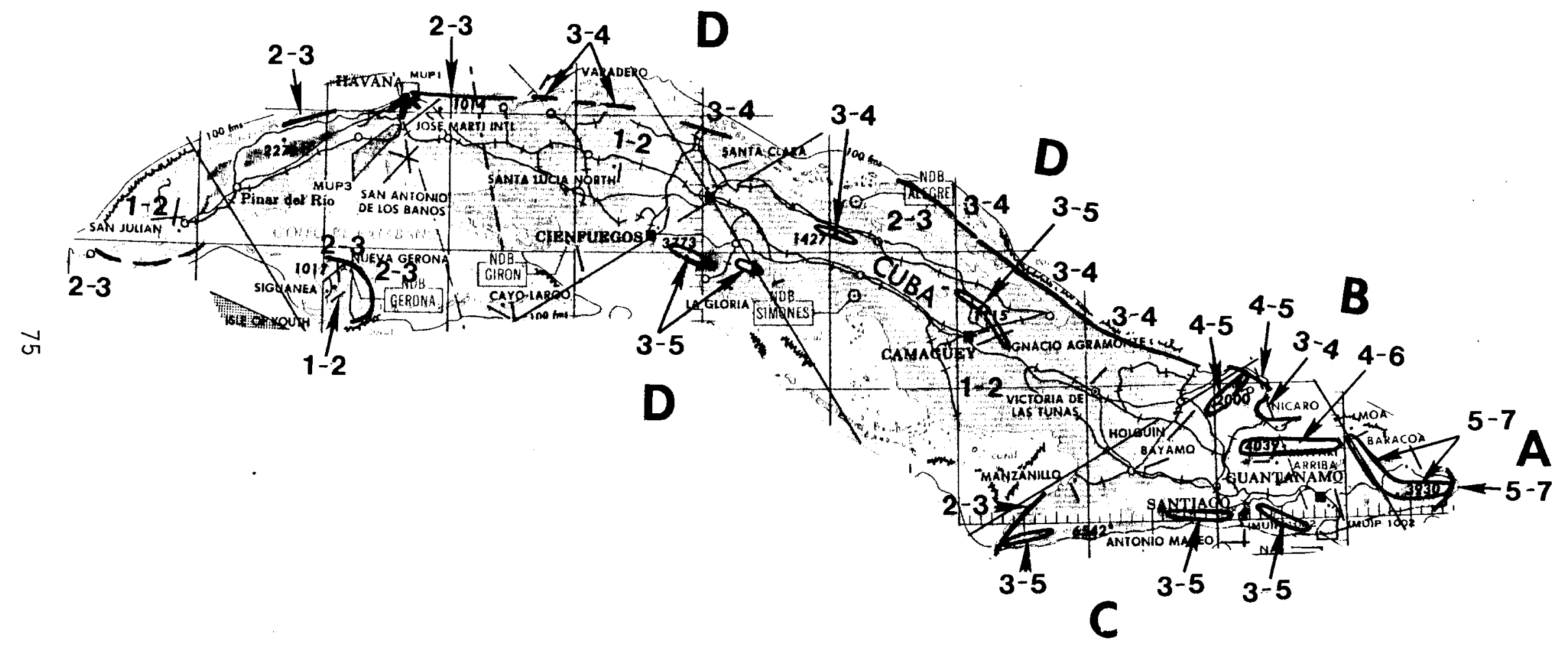




\section{BAHAMAS -}

GRAND BAHAMA AND GREAT ABACO ISLANDS

\begin{tabular}{|c|c|c|c|c|c|}
\hline Area & & $\begin{array}{l}\text { Annual } \\
\text { verage }\end{array}$ & $\begin{array}{l}\text { Useful } \\
\text { Power }\end{array}$ & $\begin{array}{l}\text { Maximum } \\
\text { Power }\end{array}$ & $\begin{array}{l}\text { Minimum } \\
\text { Power }\end{array}$ \\
\hline \multirow[t]{3}{*}{$A$} & $p$ & $3-4$ & Sep-May & Oct-Mar & Jun-Aug \\
\hline & & $2.0-2.2$ & & $P \quad 5-6$ & P $1-2$ \\
\hline & & & & $k \quad 1.8-2.5$ & \\
\hline \multirow[t]{3}{*}{ B } & $P$ & $2-3$ & Sep-May & Oct-Mar & Jun-Aug \\
\hline & & $2.0-2.2$ & & $P \quad 3-5$ & P $1-2$ \\
\hline & & & & k $\quad 1.8-2.5$ & \\
\hline
\end{tabular}




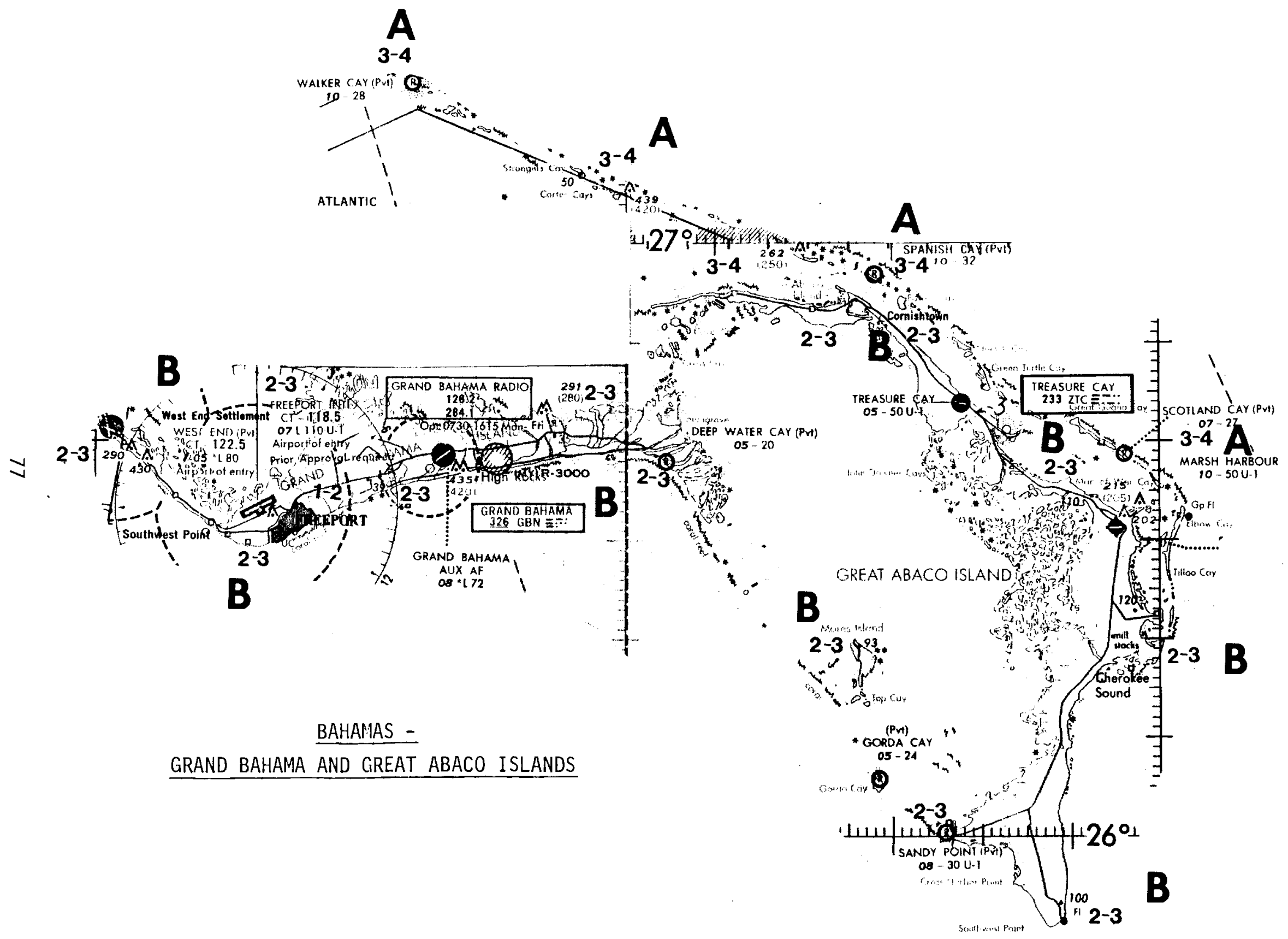


BAHAMAS -

ANDROS, BERRY, AND NEW PROVIDENCE

\begin{tabular}{lllll}
\hline Area & $\begin{array}{c}\text { Annual } \\
\text { Average }\end{array}$ & $\begin{array}{l}\text { Useful } \\
\text { Power }\end{array}$ & $\begin{array}{c}\text { Maximum } \\
\text { Power }\end{array}$ & $\begin{array}{c}\text { Minimum } \\
\text { Power }\end{array}$ \\
\hline A & $P \quad 2-3$ & Oct-May & Oct-Mar & Jun-Sep \\
& $k 1.8-2.0$ & & P $3-5$ & P $1-2$ \\
& & & $k 1.8-2.4$
\end{tabular}




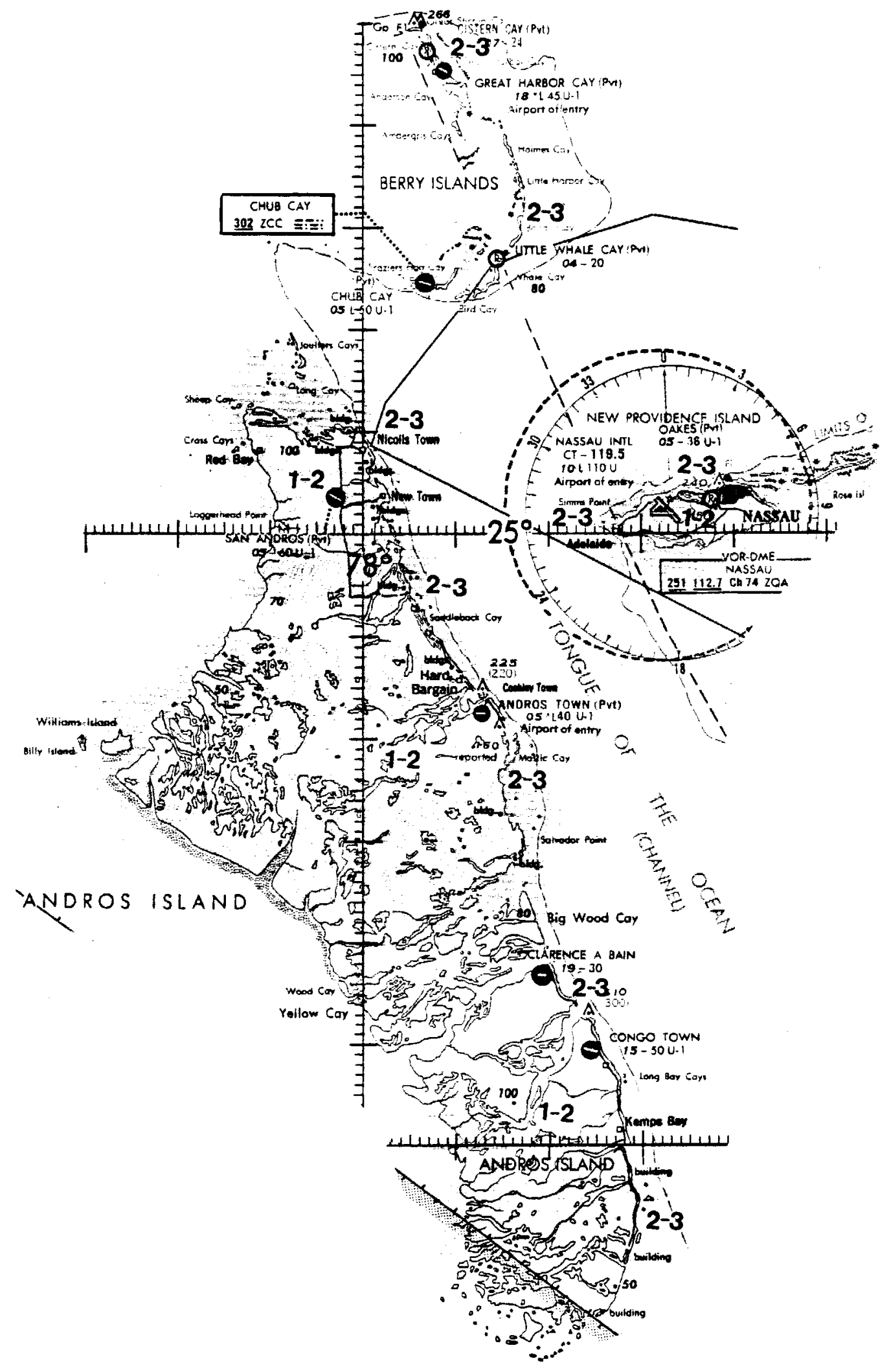


BAHAMAS -

CAT, ELEUTHERA, AND GREAT EXUMA ISLANDS

\begin{tabular}{lllll}
\hline Area & $\begin{array}{c}\text { Annual } \\
\text { Average }\end{array}$ & $\begin{array}{l}\text { Usefu1 } \\
\text { Power }\end{array}$ & $\begin{array}{c}\text { Maximum } \\
\text { Power }\end{array}$ & $\begin{array}{c}\text { Minimum } \\
\text { Power }\end{array}$ \\
\hline A & P $3-4$ & All except & Nov-Jan & May-Sep \\
& $k 2.2-2.5$ & Jun, Aug & P 5-6 & P 2-3 \\
& & & $k 2.2-2.8$ &
\end{tabular}




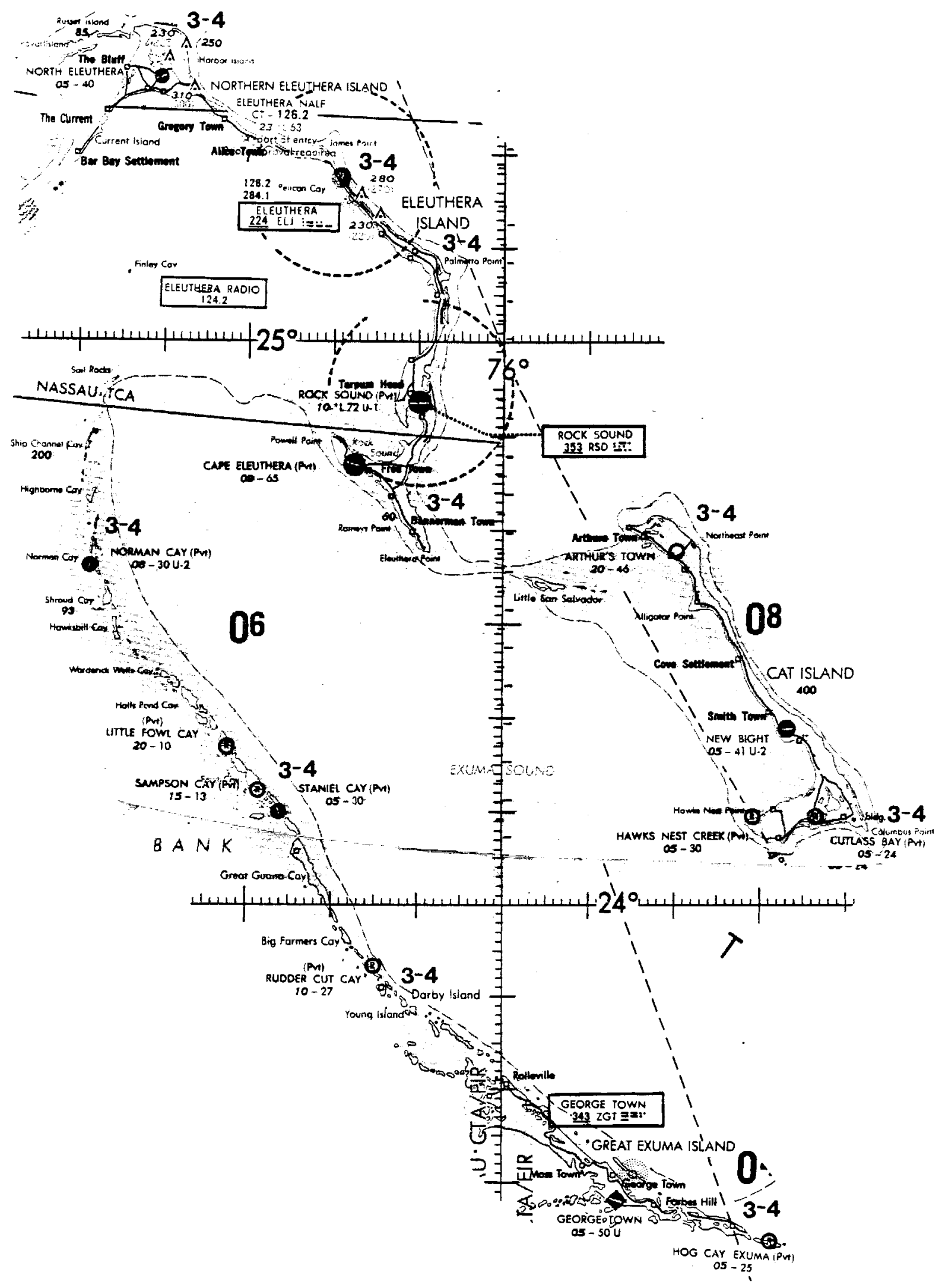


BAHAMAS -

ACKLINS, CROOKED, LONG, AND SAN SALVADOR ISLANDS

\begin{tabular}{|c|c|c|c|c|c|}
\hline Area & & $\begin{array}{l}\text { Annual } \\
\text { verage }\end{array}$ & $\begin{array}{l}\text { Useful } \\
\text { Power }\end{array}$ & $\begin{array}{l}\text { Maximum } \\
\text { Power }\end{array}$ & $\begin{array}{l}\text { Minimum } \\
\text { Power }\end{array}$ \\
\hline \multirow[t]{3}{*}{ A } & $P$ & $4-5$ & All year & Nov-Jan & May-Jun, \\
\hline & $k$ & $2.4-2.6$ & & $P \quad 5-6$ & Sep-oct \\
\hline & & & & k 2.4-3.0 & $P \quad 2-3$ \\
\hline \multirow[t]{3}{*}{ B } & $\mathrm{P}$ & $4-5$ & All year & Nov-Jan & May-Sep \\
\hline & & $2.4-2.6$ & & P 6 & $P \quad 2-3$ \\
\hline & & & & k 2.4-2.8 & \\
\hline
\end{tabular}




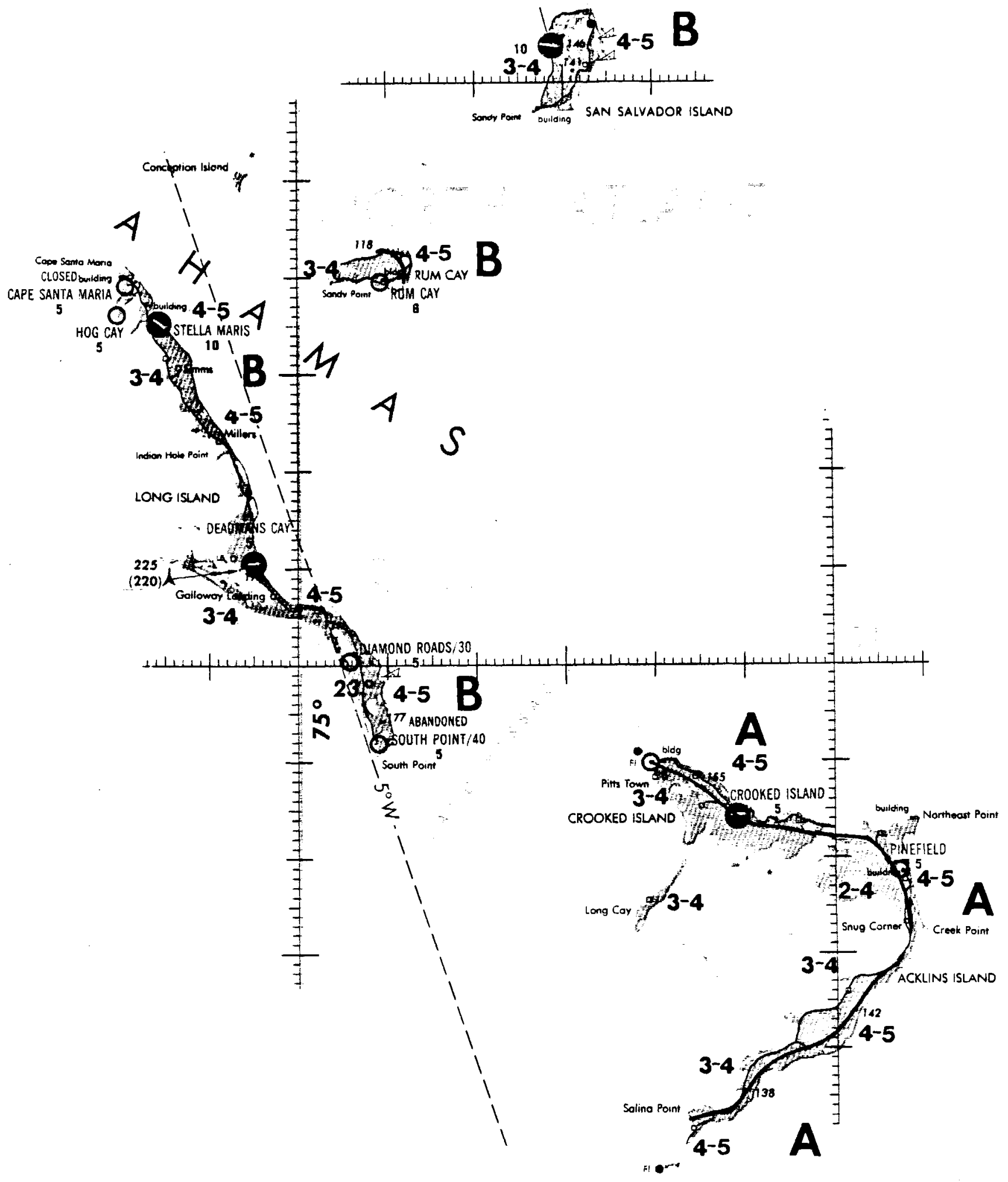


BAHAMAS - INAGUA AND MAYAGUANA ISLANDS

\begin{tabular}{|c|c|c|c|c|c|}
\hline Area & & $\begin{array}{l}\text { Annual } \\
\text { verage }\end{array}$ & $\begin{array}{l}\text { Useful } \\
\text { Power }\end{array}$ & $\begin{array}{l}\text { Maximum } \\
\text { Power }\end{array}$ & $\begin{array}{l}\text { Minimum } \\
\text { Power }\end{array}$ \\
\hline \multirow[t]{3}{*}{ A } & $P$ & $4-6$ & All year & Ju1-Aug & Sep-0ct \\
\hline & & $2.6-2.8$ & & P 6 & P $3-4$ \\
\hline & & & & $k \quad 3.4-4.6$ & \\
\hline \multirow[t]{3}{*}{ B } & $P$ & $3-4$ & All except & Ju1-Aug & Sep-0ct \\
\hline & & $2.6-2.8$ & Sep-0ct & $P \quad 4-5$ & P 2 \\
\hline & & & & k $\quad 3.4-4.6$ & \\
\hline
\end{tabular}




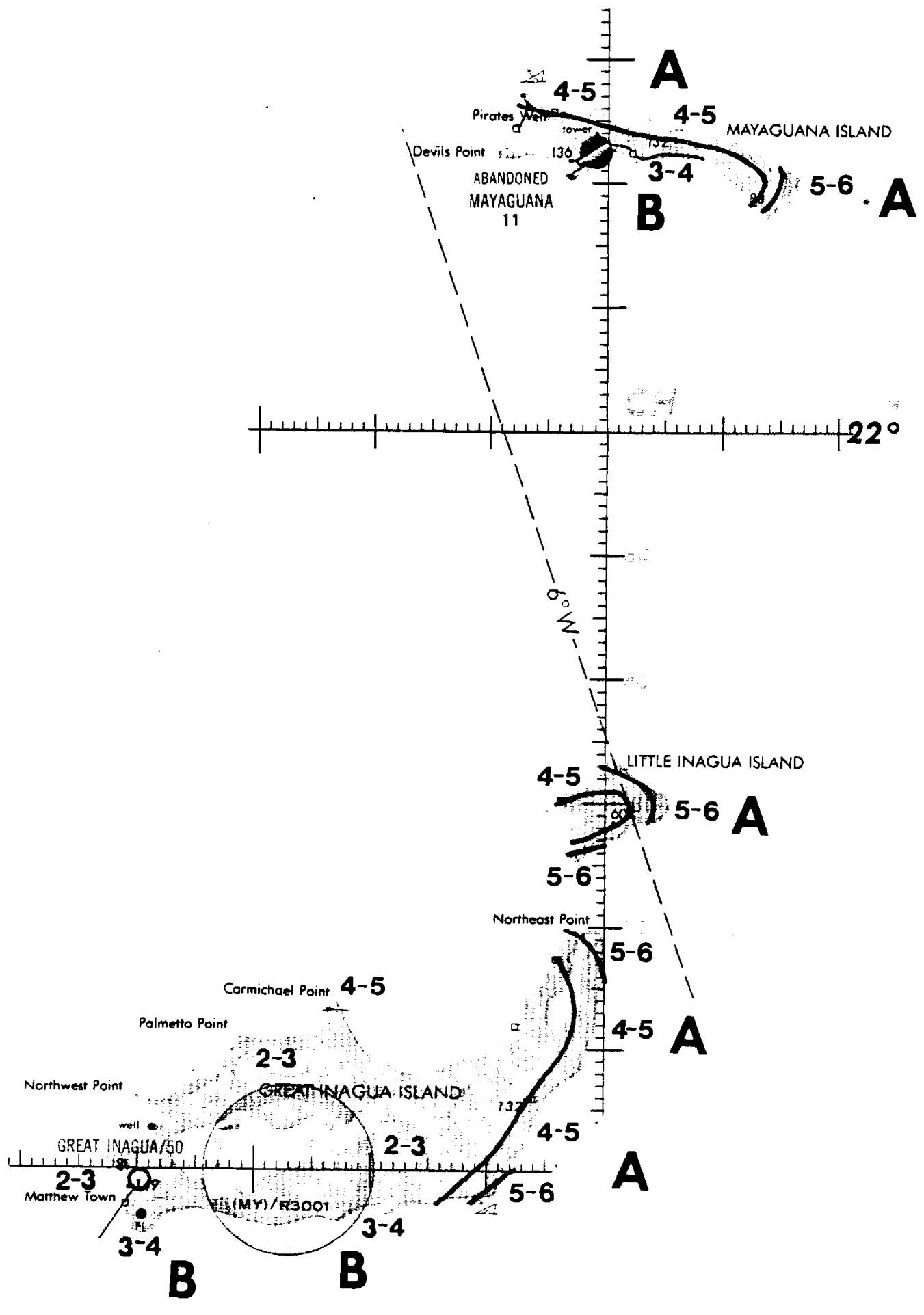




\section{TURKS AND CAICOS ISLANDS}

\begin{tabular}{|c|c|c|c|c|c|}
\hline Area & & $\begin{array}{l}\text { Annual } \\
\text { verage }\end{array}$ & $\begin{array}{l}\text { Useful } \\
\text { Power }\end{array}$ & $\begin{array}{l}\text { Maximum } \\
\text { Power }\end{array}$ & $\begin{array}{l}\text { Minimum } \\
\text { Power }\end{array}$ \\
\hline \multirow[t]{3}{*}{$A$} & $P$ & $4-6$ & All year & Jul-Aug & Sep-0ct \\
\hline & k & $2.6-3.0$ & & P 6 & P $\quad 3-4$ \\
\hline & & & & k 3.6-5.0 & \\
\hline \multirow[t]{3}{*}{ B } & $P$ & $3-4$ & All except & Jul-Aug & Sep-0ct \\
\hline & k & $2.6-3.0$ & Sep-Oct & $P \quad 4-5$ & P 2 \\
\hline & & & & k $3.6-5.0$ & \\
\hline
\end{tabular}




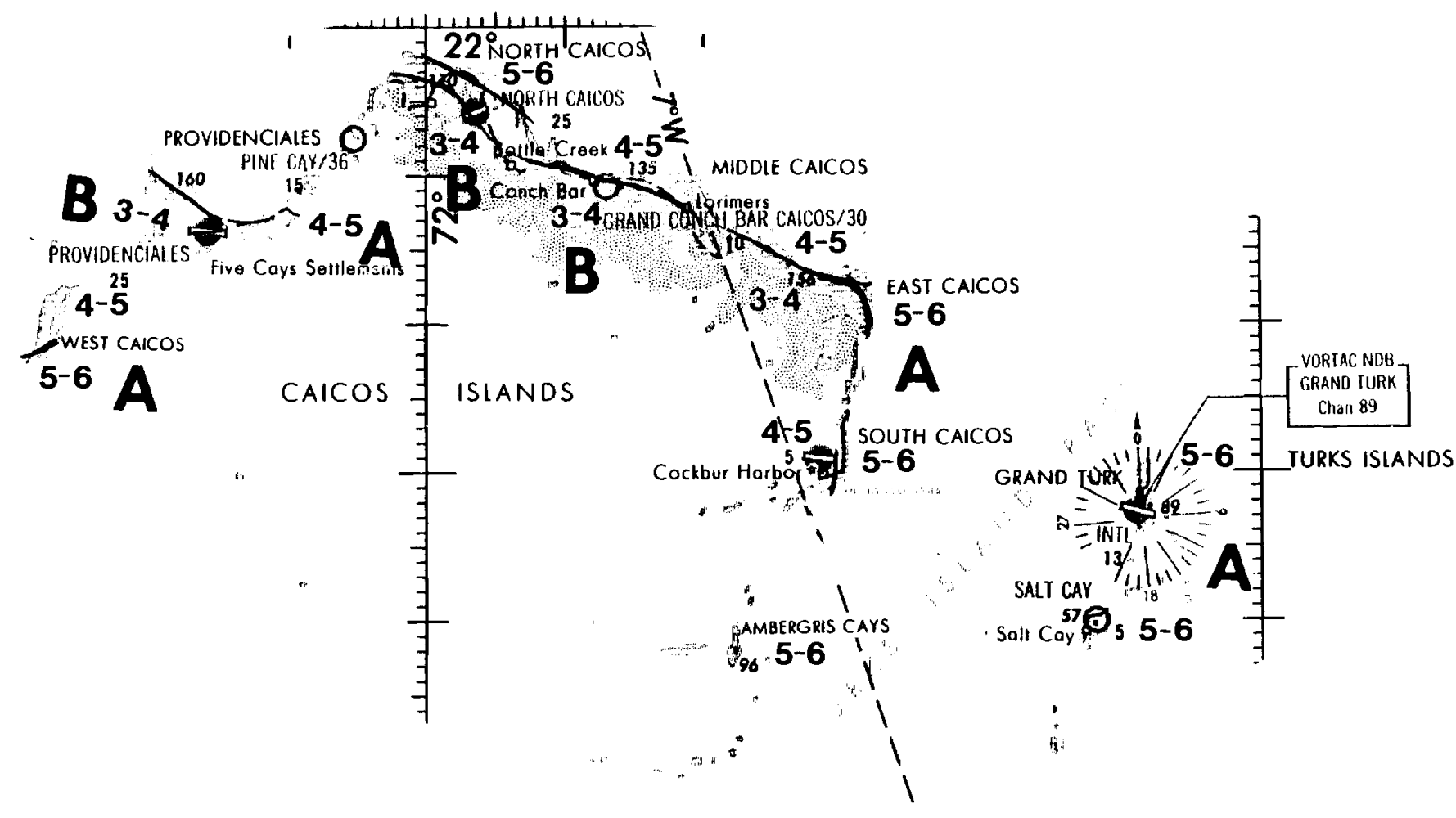


ARUBA, BONAIRE, CURACAO

\begin{tabular}{lllll}
\hline Area & $\begin{array}{c}\text { Annual } \\
\text { Average }\end{array}$ & $\begin{array}{l}\text { Useful } \\
\text { Power }\end{array}$ & $\begin{array}{c}\text { Maximum } \\
\text { Power }\end{array}$ & $\begin{array}{c}\text { Minimum } \\
\text { Power }\end{array}$ \\
\hline & P $5-7$ & All year & May-Jul & Nov \\
$k 3.8$ & & P 6-7 & P 3-4 \\
& & $k 4.0-5.0$ &
\end{tabular}



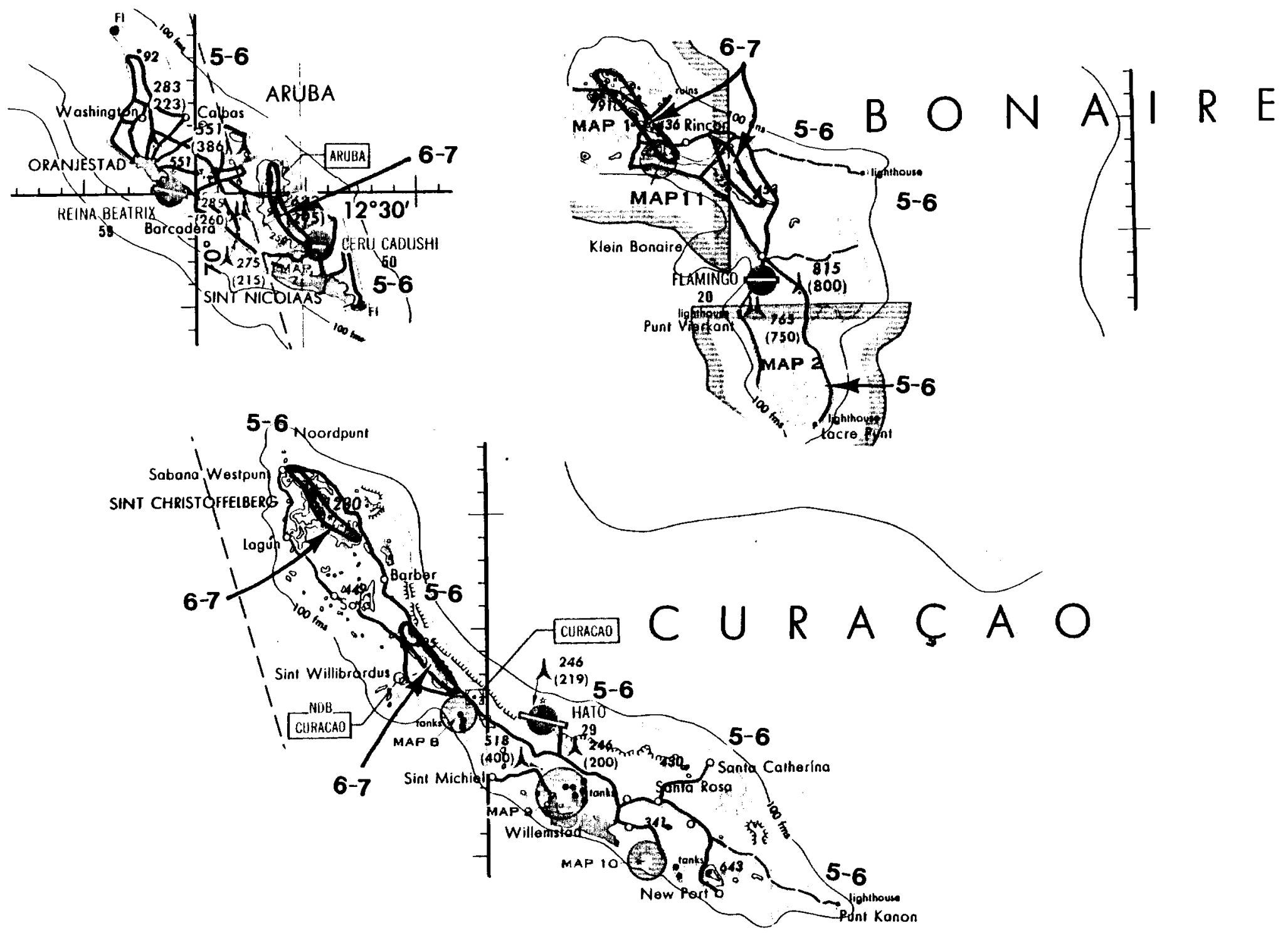
TRINIDAD AND TOBAGO

\begin{tabular}{lllll}
\hline Area & $\begin{array}{c}\text { Annual } \\
\text { Average }\end{array}$ & $\begin{array}{l}\text { Useful } \\
\text { Power }\end{array}$ & $\begin{array}{c}\text { Maximum } \\
\text { Power }\end{array}$ & $\begin{array}{c}\text { Minimum } \\
\text { Power }\end{array}$ \\
\hline A & P $3-5$ & Nov-Jul & Jan-Feb, Jun & Aug-Oct \\
& $k 3.2-3.4$ & & P 5-6 & P $1-2$ \\
& & & $k 3.8-4.4$ & \\
B & P 2-3 & Dec-Jun & Jan-Feb, Jun & Ju1-Nov \\
& $k 3.2-3.4$ & & P 3-4 & P 1-2
\end{tabular}




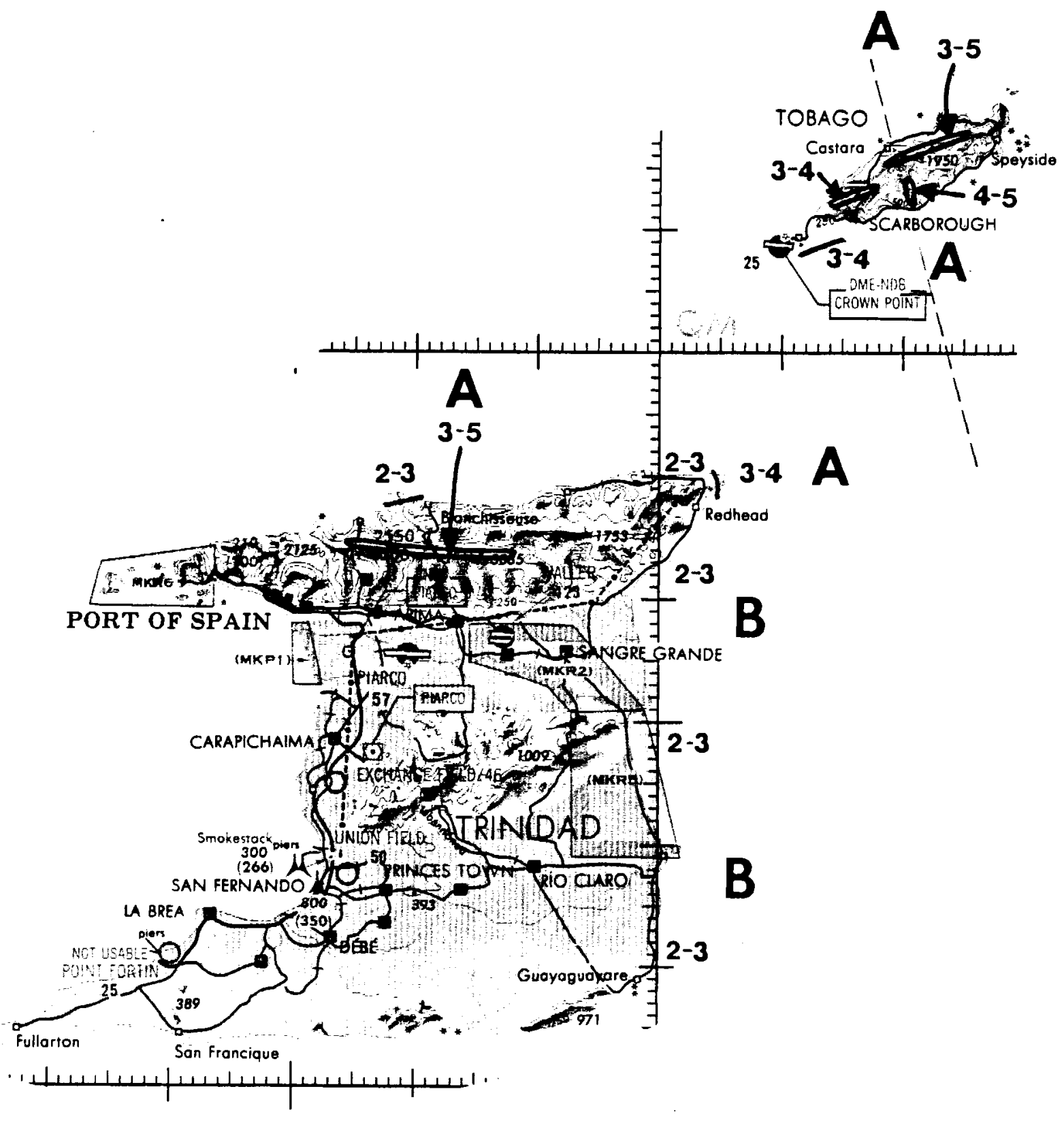




\section{VENEZUELA COAST AND ISLANDS}

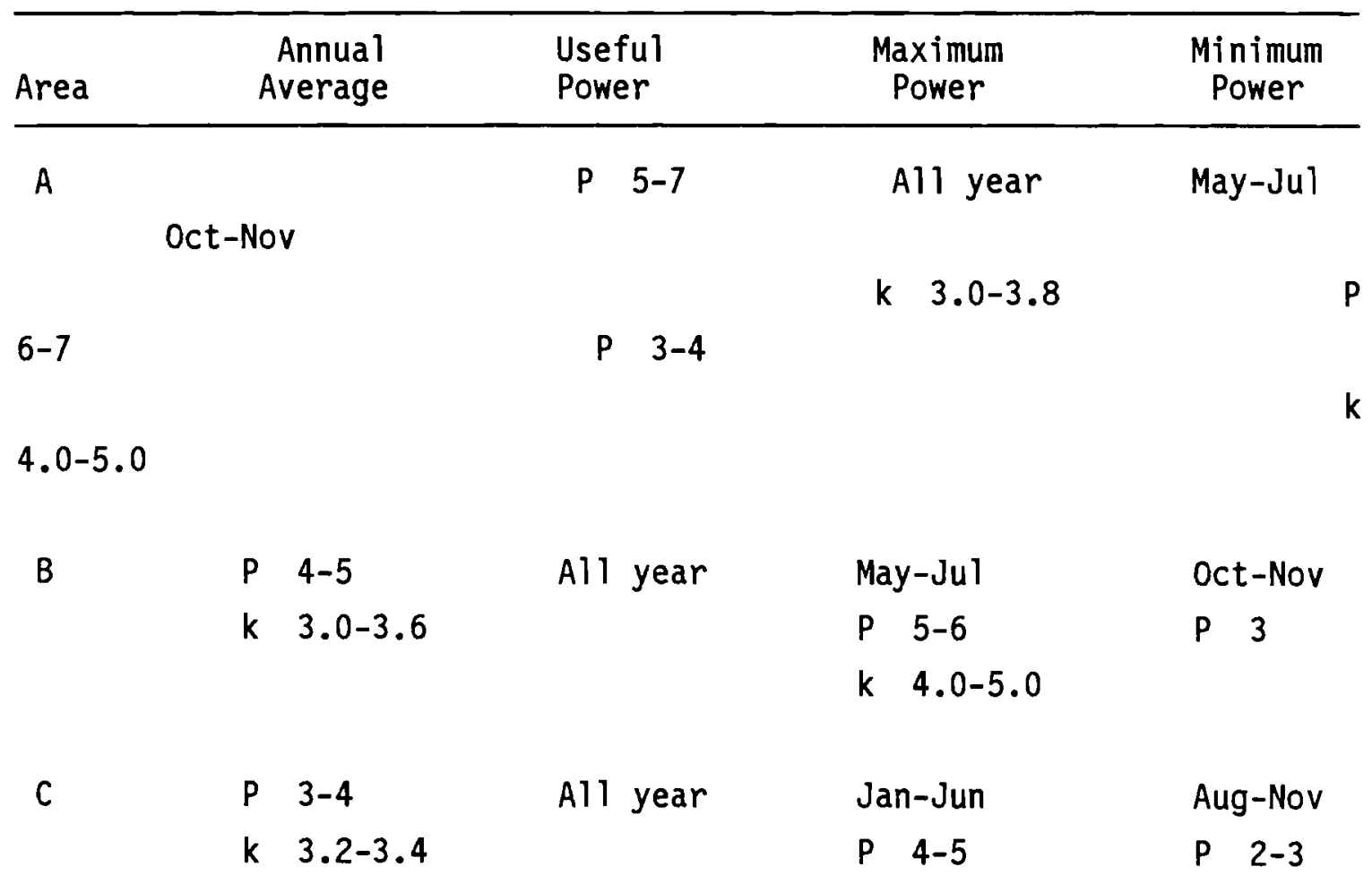




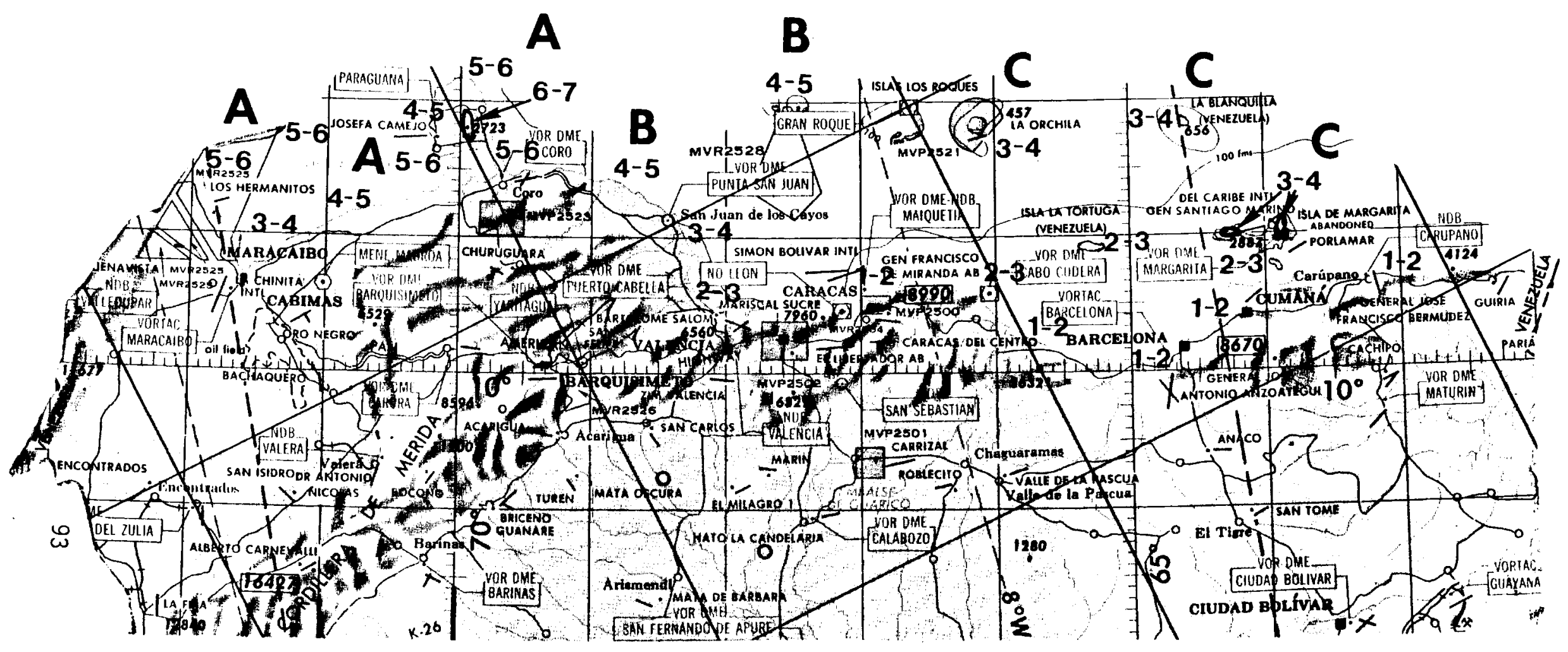


COLUMBIA COAST AND ISLANDS

\begin{tabular}{|c|c|c|c|c|c|}
\hline Area & & $\begin{array}{l}\text { Annual } \\
\text { erage }\end{array}$ & $\begin{array}{l}\text { Useful } \\
\text { Power }\end{array}$ & $\begin{array}{l}\text { Maximum } \\
\text { Power }\end{array}$ & $\begin{array}{c}\text { Minimum } \\
\text { Power }\end{array}$ \\
\hline$A$ & & $\begin{array}{l}6-7 \\
3.6-3.8\end{array}$ & All year & $\begin{array}{l}\text { May-Jul } \\
\text { P } 7 \\
\text { k } 4.2-4.6\end{array}$ & $\begin{array}{l}\text { Oct-Dec } \\
P \quad 4-5\end{array}$ \\
\hline B & $\begin{array}{l}P \\
k\end{array}$ & $\begin{array}{l}6-7 \\
3.0-3.2\end{array}$ & All year & $\begin{array}{l}\text { Jan-Aug } \\
\text { P } 7 \\
\text { k } 3.8-4.4\end{array}$ & $\begin{array}{l}\text { Oct-Nov } \\
P \quad 4-5\end{array}$ \\
\hline$C$ & $\begin{array}{l}P \\
k\end{array}$ & $\begin{array}{l}7 \\
2.8-3.0\end{array}$ & All year & $\begin{array}{l}\text { Jan-Mar } \\
\text { P } 7++ \\
\text { k } 4.4-4.6\end{array}$ & $\begin{array}{l}\text { Sep-Oct } \\
\text { p 2-3 }\end{array}$ \\
\hline$D$ & $\begin{array}{l}P \\
k\end{array}$ & $\begin{array}{l}3-6 \\
1.8-2.6\end{array}$ & Dec-Aug & $\begin{array}{l}\text { Dec-Apr } \\
\text { P } 5-7 \\
\text { k } \quad 3.2-4.2\end{array}$ & $\begin{array}{l}\text { Sep-Nov } \\
\text { P } 1-2\end{array}$ \\
\hline
\end{tabular}




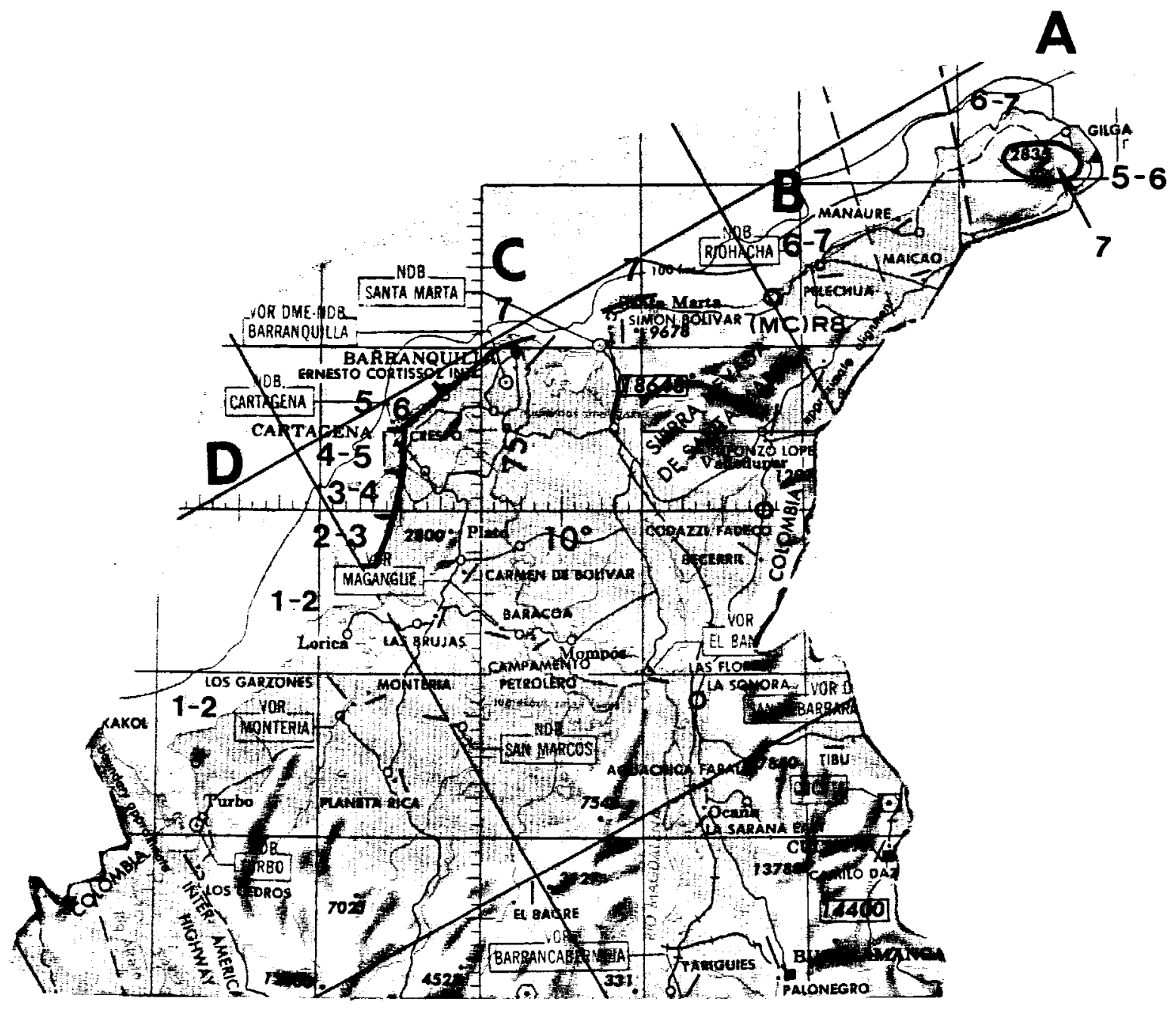




\section{PANAMA}

\begin{tabular}{|c|c|c|c|c|c|}
\hline Area & & $\begin{array}{l}\text { Annual } \\
\text { verage }\end{array}$ & $\begin{array}{l}\text { Useful } \\
\text { Power }\end{array}$ & $\begin{array}{l}\text { Maximum } \\
\text { Power }\end{array}$ & Minimum \\
\hline \multirow[t]{3}{*}{$A$} & $P$ & $2-3$ & Dec-Apr & Dec-Mar & Jun, \\
\hline & k & $1.7-2.0$ & & $P \quad 4-6$ & Aug-0ct \\
\hline & & & & k 2.5-3.0 & P 1 \\
\hline \multirow[t]{3}{*}{ B } & $\mathrm{P}$ & $1-2$ & Jan-Mar & Jan-Feb & Jun-0ct \\
\hline & k & $1.6-2.0$ & & $P \quad 4-5$ & P 1 \\
\hline & & & & $k \quad 2.0-3.0$ & \\
\hline
\end{tabular}




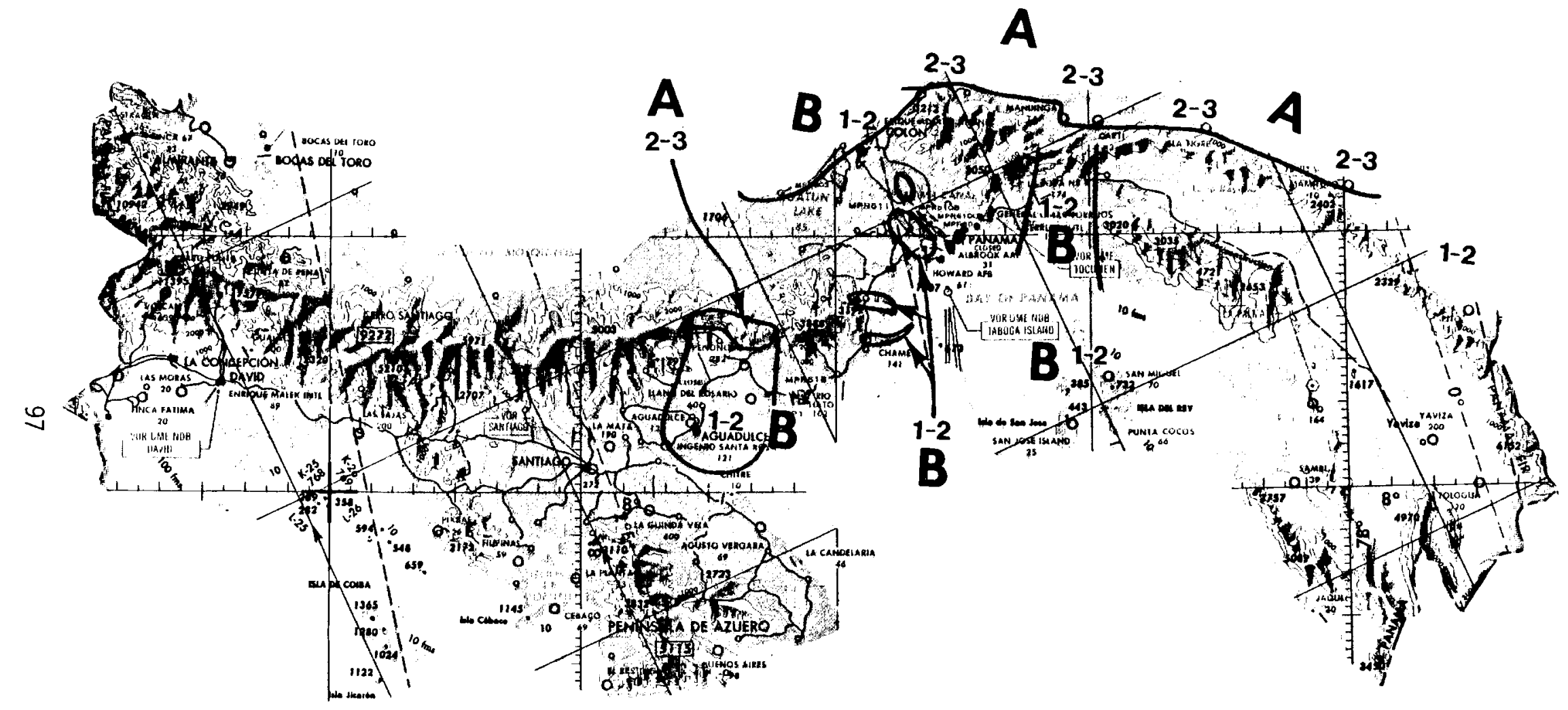


COSTA RICA

\begin{tabular}{|c|c|c|c|c|c|}
\hline Area & & $\begin{array}{l}\text { Annual } \\
\text { verage }\end{array}$ & $\begin{array}{l}\text { Useful } \\
\text { Power }\end{array}$ & $\begin{array}{l}\text { Maximum } \\
\text { Power }\end{array}$ & $\begin{array}{l}\text { Minimum } \\
\text { Power }\end{array}$ \\
\hline \multirow[t]{3}{*}{ A } & $P$ & $3-5$ & Nov-Apr, & Dec-Mar & Sep-0ct \\
\hline & $k$ & $1.5-1.8$ & Jul & $P \quad 6-7$ & P $1-2$ \\
\hline & & & & k 2.1-2.6 & \\
\hline \multirow[t]{3}{*}{ B } & $P$ & $2-3$ & Dec-Apr & Jan-Feb & Sep-Oct \\
\hline & $\mathrm{k}$ & $1.4-1.8$ & & $P \quad 4-5$ & P 1 \\
\hline & & & & k $1.8-2.3$ & \\
\hline \multirow[t]{3}{*}{ C } & $P$ & $3-4$ & Nov-Apr, & Dec-Mar & Sep-0ct \\
\hline & k & $1.5-1.8$ & $J u 1$ & $P \quad 5-6$ & P 1 \\
\hline & & & & k 2.1-2.6 & \\
\hline
\end{tabular}




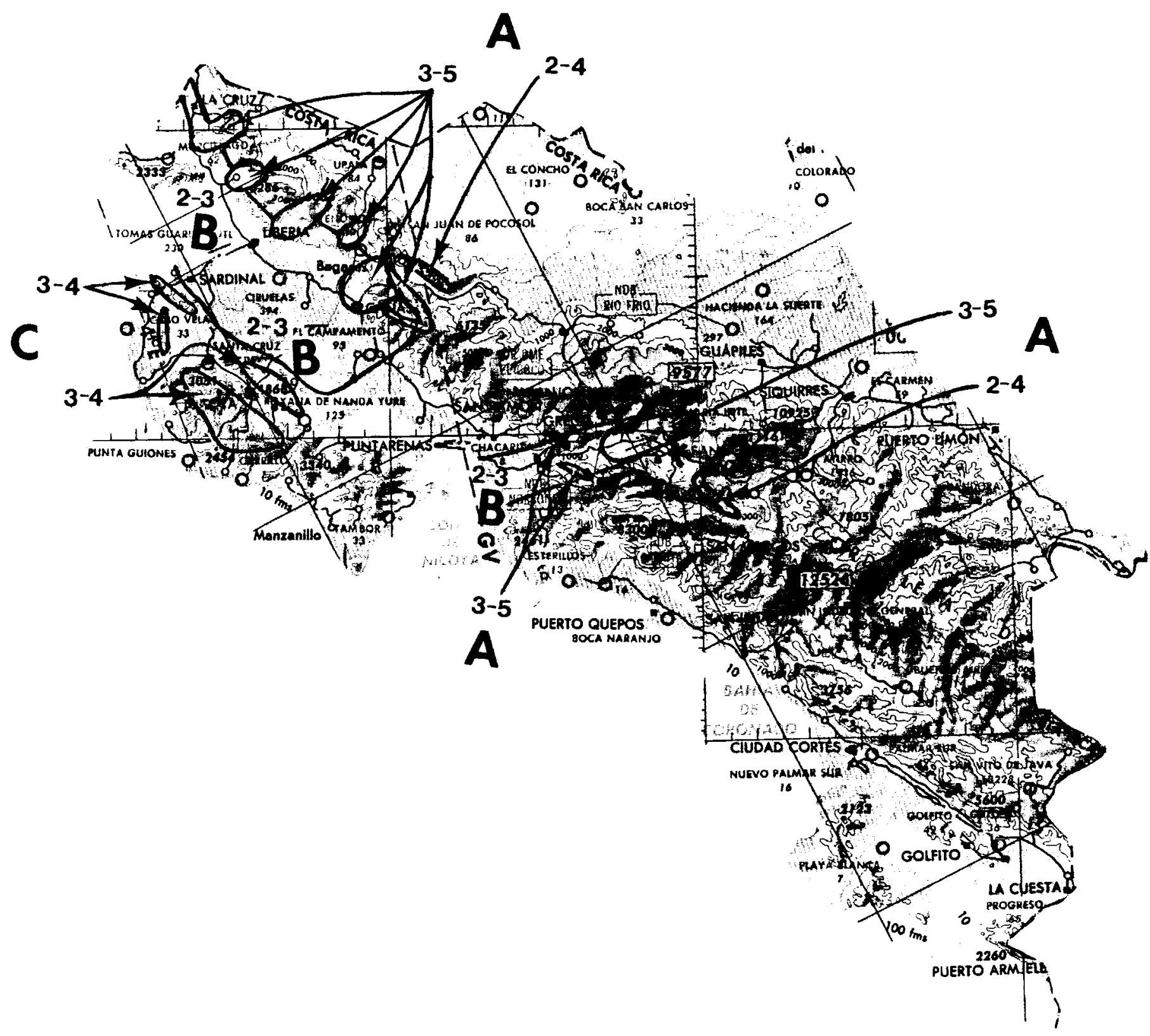


NICARAGUA

\begin{tabular}{|c|c|c|c|c|c|}
\hline Area & & $\begin{array}{l}\text { nnual } \\
\text { erage }\end{array}$ & $\begin{array}{l}\text { Useful } \\
\text { Power }\end{array}$ & $\begin{array}{l}\text { Maximum } \\
\text { Power }\end{array}$ & $\begin{array}{l}\text { Minimum } \\
\text { Power }\end{array}$ \\
\hline \multirow[t]{3}{*}{ A } & P & $3-5$ & Nov-Apr, & Dec-Mar & Sep-0ct \\
\hline & k & $1.5-1.8$ & Jul-Aug & $P \quad 6-7$ & P $1-2$ \\
\hline & & & & k 2.1-2.6 & \\
\hline \multirow[t]{3}{*}{ B } & $\mathbf{P}$ & $2-3$ & Dec-Apr & Jan-Feb & Sep-Oct \\
\hline & k & $1.4-1.8$ & & $P \quad 4-5$ & P 1 \\
\hline & & & & k $1.8-2.3$ & \\
\hline \multirow[t]{3}{*}{ C } & $P$ & $2-3$ & Nov-Jul & Jan, Mar, Jul & Sep-Oct \\
\hline & $k$ & $2.8-3.2$ & & P $\quad 3-4$ & $1-2$ \\
\hline & & & & k $\quad 3.0-3.6$ & \\
\hline
\end{tabular}




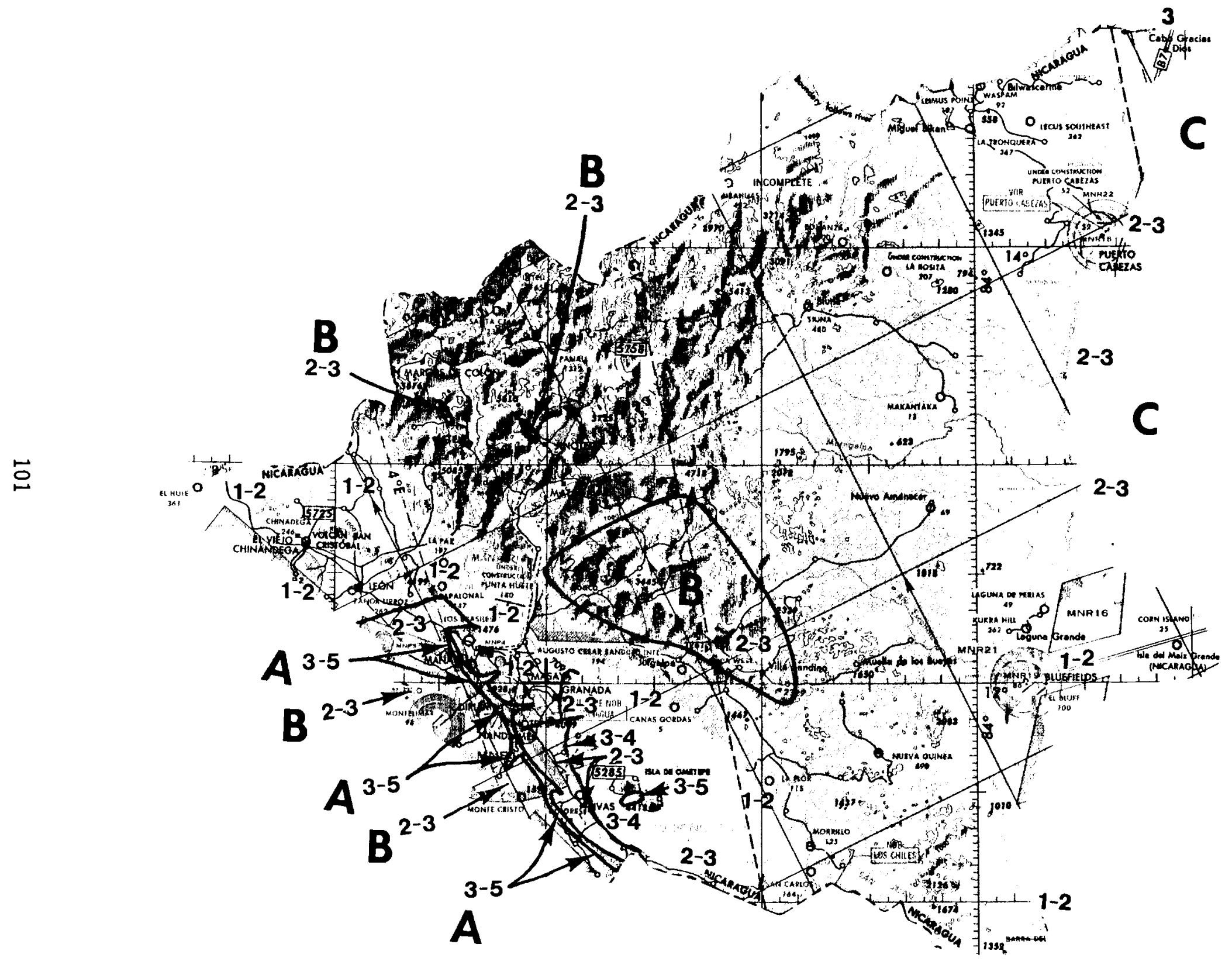


HONDURAS

\begin{tabular}{|c|c|c|c|c|c|}
\hline Area & & $\begin{array}{l}\text { Annual } \\
\text { lerage }\end{array}$ & $\begin{array}{l}\text { Useful } \\
\text { Power }\end{array}$ & $\begin{array}{l}\text { Maximum } \\
\text { Power }\end{array}$ & $\begin{array}{l}\text { Minimum } \\
\text { Power }\end{array}$ \\
\hline \multirow[t]{3}{*}{$A$} & $\mathbf{P}$ & $2-3$ & Nov-Mar & Dec-Feb & May-0ct \\
\hline & k & $1.5-1.7$ & & $P \quad 4-6$ & $P \quad 1-2$ \\
\hline & & & & k $\quad 1.8-2.3$ & \\
\hline \multirow[t]{3}{*}{ B } & $P$ & $1-2$ & Dec-Mar & Jan-Feb & May-0ct \\
\hline & k & $1.4-1.7$ & & $P \quad 3-5$ & P 1 \\
\hline & & & & k $1.8-2.3$ & \\
\hline \multirow[t]{4}{*}{ C } & $P$ & 3 & Nov-Jul & Jan, Mar, & Aug-0ct \\
\hline & k & $2.8-3.2$ & & Jun-Jul & P 2 \\
\hline & & & & P 4 & \\
\hline & & & & $k \quad 3.0-4.0$ & \\
\hline \multirow[t]{4}{*}{$D$} & $P$ & $2-3$ & Nov-Jul & Mar-Apr, & Aug-0ct \\
\hline & $k$ & $2.4-2.8$ & & Jun-Jul & $P \quad 1-2$ \\
\hline & & & & P $\quad 3-4$ & \\
\hline & & & & k 2.8-3.8 & \\
\hline
\end{tabular}




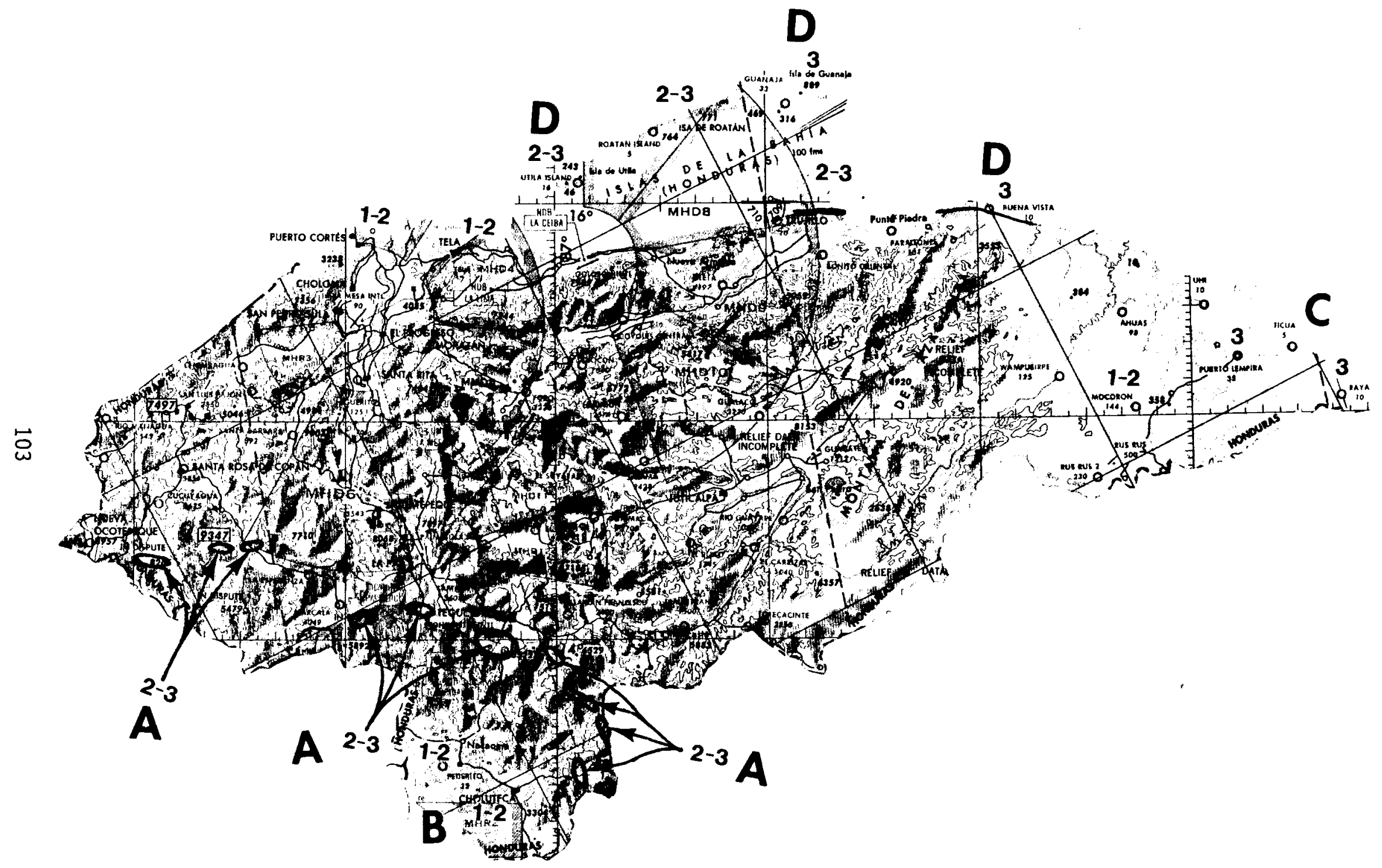


EL SALVADOR

\begin{tabular}{lllll}
\hline Area & $\begin{array}{c}\text { Annual } \\
\text { Average }\end{array}$ & $\begin{array}{l}\text { Useful } \\
\text { Power }\end{array}$ & $\begin{array}{c}\text { Maximum } \\
\text { Power }\end{array}$ & $\begin{array}{c}\text { Minimum } \\
\text { Power }\end{array}$ \\
\hline A & P $2-3$ & Nov-Mar & Dec-Feb & May-Oct \\
& $k 1.5-1.7$ & & P $4-6$ & P 1 \\
& & & $k 1.8-2.3$
\end{tabular}




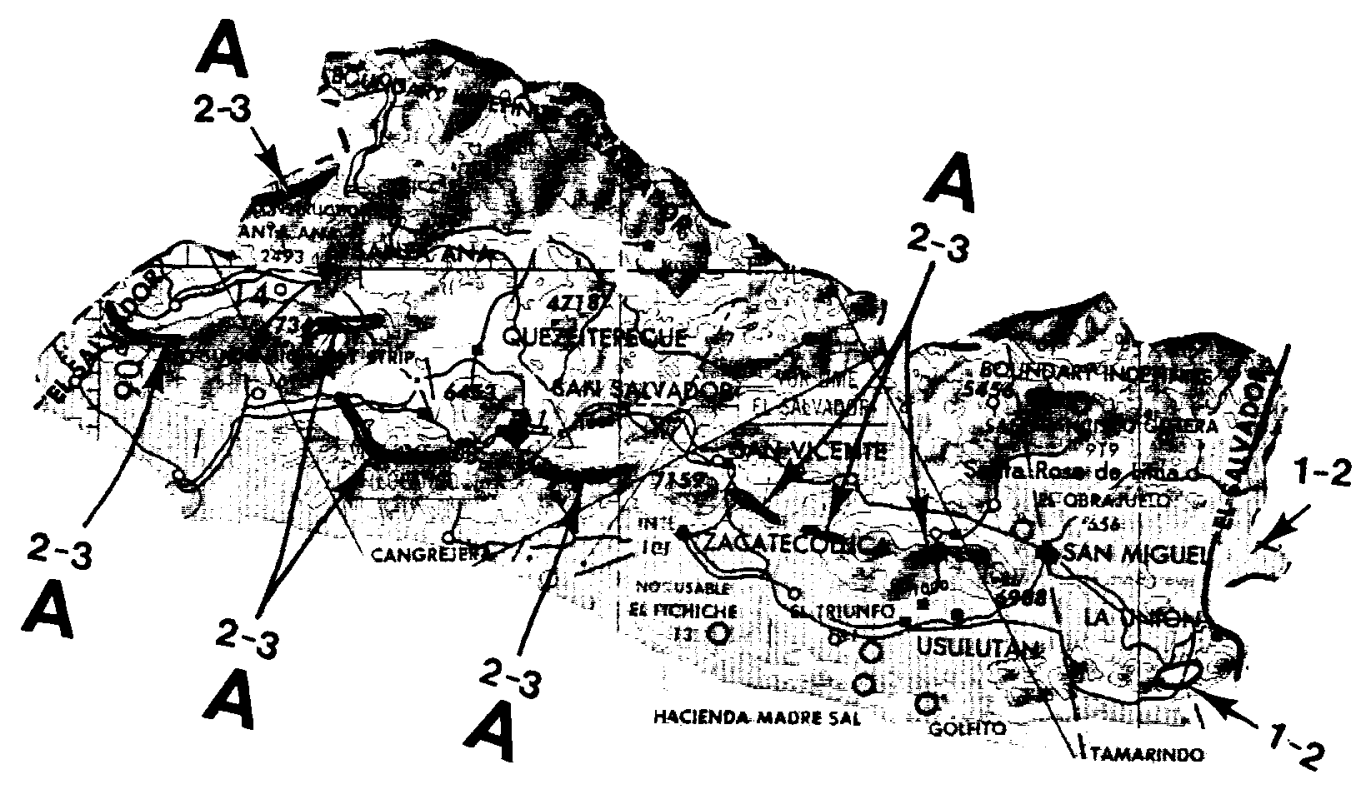




\section{GUATEMALA}

\begin{tabular}{lllll}
\hline Area & $\begin{array}{c}\text { Annual } \\
\text { Average }\end{array}$ & $\begin{array}{l}\text { Usefut } \\
\text { Power }\end{array}$ & $\begin{array}{l}\text { Maximum } \\
\text { Power }\end{array}$ & $\begin{array}{c}\text { Minimum } \\
\text { Power }\end{array}$ \\
\hline A & $P 2-3$ & Nov-Mar & Dec-Feb & May-Oct \\
& $k 1.5-1.7$ & & P $4-6$ & P 1 \\
& & & $k 1.8-2.3$
\end{tabular}




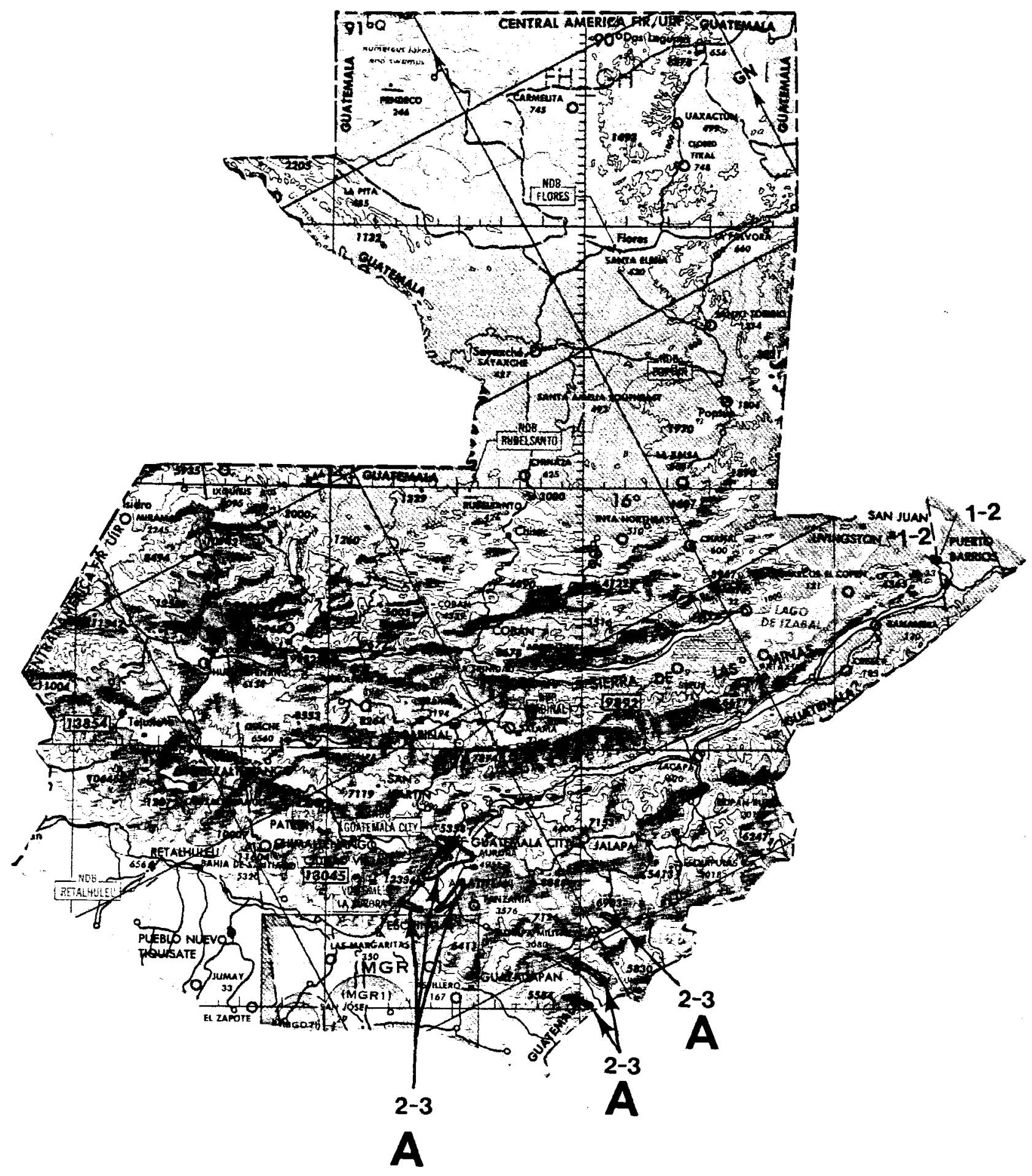




\section{BELIZE}

\begin{tabular}{|c|c|c|c|c|c|}
\hline Area & & $\begin{array}{l}\text { Annual } \\
\text { verage }\end{array}$ & $\begin{array}{l}\text { Useful } \\
\text { Power }\end{array}$ & $\begin{array}{l}\text { Maximum } \\
\text { Power }\end{array}$ & $\begin{array}{l}\text { Minimum } \\
\text { Power }\end{array}$ \\
\hline \multirow[t]{3}{*}{$A$} & $P$ & $3-4$ & Nov-Aug & Feb-Apr, Jun & Sep-Oct \\
\hline & k & $2.8-3.0$ & & $P \quad 4-5$ & P 2 \\
\hline & & & & k $3.2-3.6$ & \\
\hline \multirow[t]{4}{*}{$B$} & $P$ & $2-3$ & Nov-Aug & Mar-Apr, & Sep-0ct \\
\hline & & $2.2-2.8$ & & Jun-JuT & P $\quad 1-2$ \\
\hline & & & & P $3-4$ & \\
\hline & & & & k 2.6-3.4 & \\
\hline
\end{tabular}




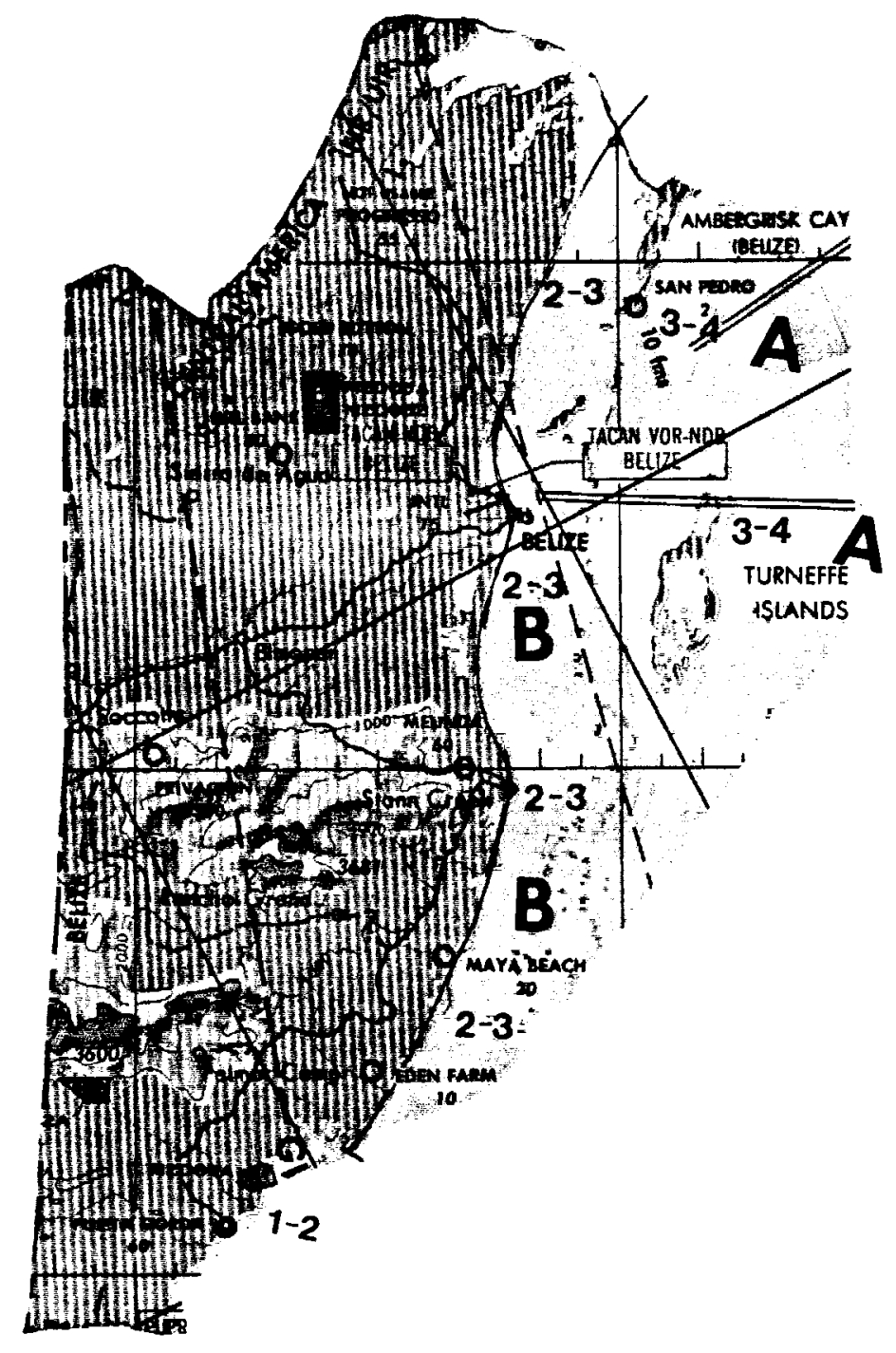


SOUTHERN MEXICO

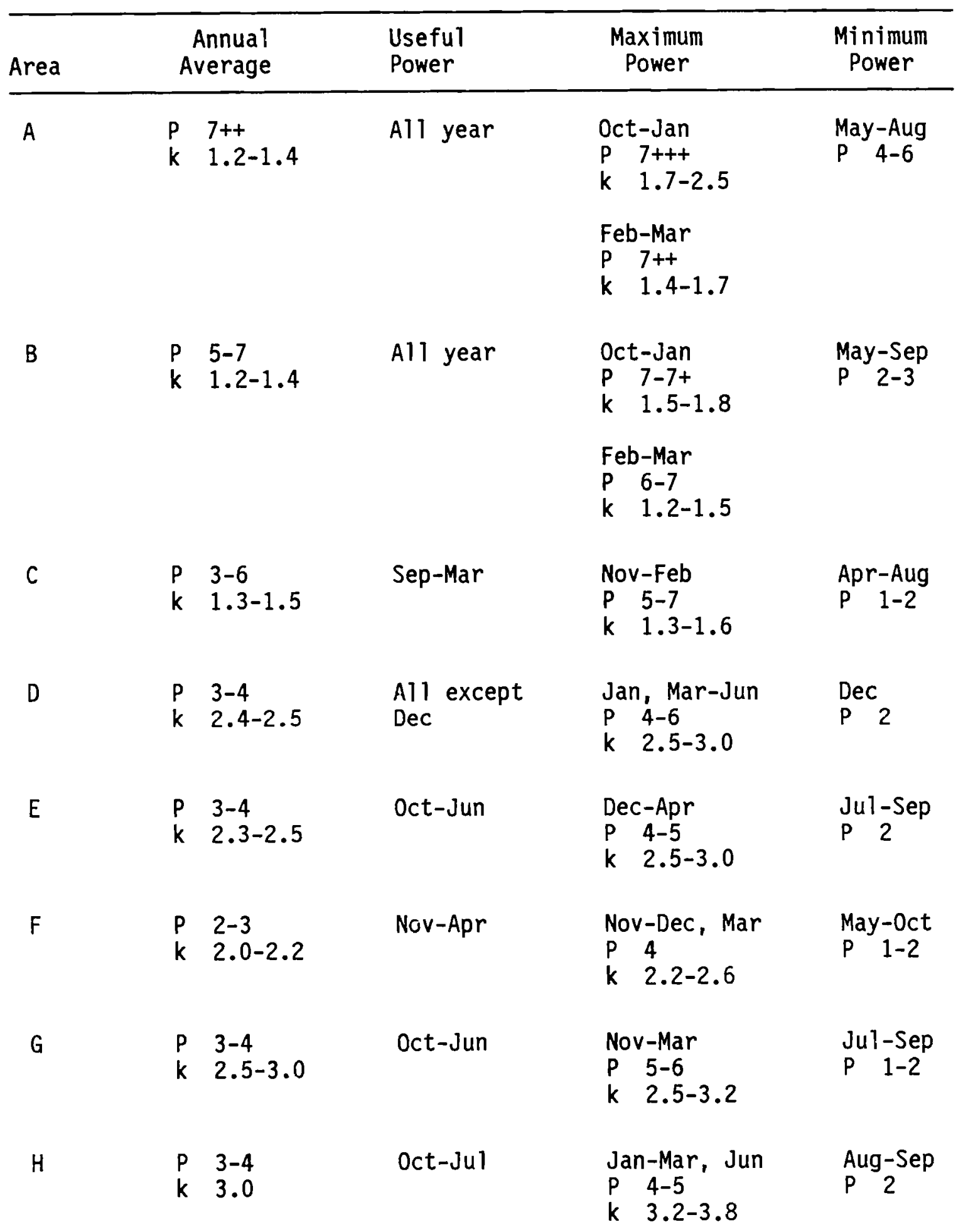




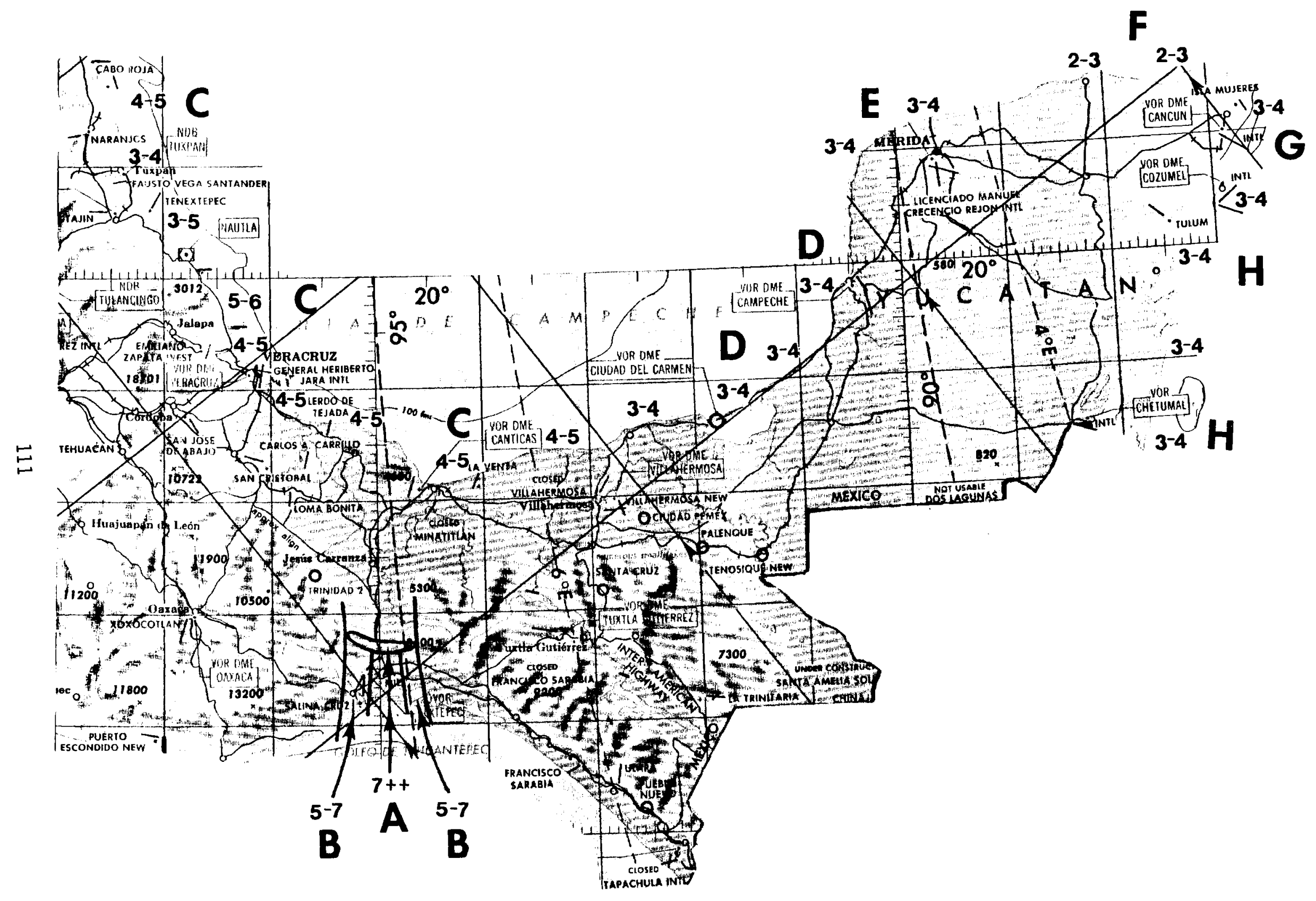




\section{.}




\section{REFERENCES}

Aleman, P. A. M., and E. Garcia. 1974. "The Climate of Mexico." Climates of North America, World Survey of Climatology, R. Bryson and F. Hare, Eds., World Survey of Climatology, Vol. 11, Elsevier Science, pp. 345-404.

Bryson, R. A., and F. K. Hare, Eds. 1983. "Climates of North America." World Survey of Climatology, Volume 11, Elsevier Science, 716 pp.

Caribbean Development Bank. 1984. Eastern Caribbean Wind Energy Resource Assessments: Country Reports. Caribbean Development Bank, Wildey, Barbados.

Cherry, N. J., D. L. Elliott, and C. I. Aspliden. 1981. "World-Wide Wind Resource Assessment." In Proceedings of Fifth Biennial Wind Energy Conference and Workshop, ed. I. E. Vas, Vol. 2, pp. 637-648. SERI/CP635-1340, CONF-811043, Volume 2, National Technical Information Service, Springfield, Virginia.

Elliott, D. L. 1979. "Meteorological and Topographical Indicators of Wind Energy for Regional Assessments," in Proceedings of the Conference on Wind Characteristics and Wind Energy Siting, pp. 273-283, American Meteorological Society, Boston, Massachusetts.

Elliott, D. L., and W. R. Barchet. 1980. Wind Energy Resource Atlas: Vol. 1 - The Northwest Region. PNL-3195 WERA-1, Pacific Northwest Laboratory, Richland, Washington.

Elliott, D. L., C. G. Holladay, W. R. Barchet, H. P. Foote, and W. F. Sandusky. 1987. Wind Energy Resource Atlas of the United States. DOE/CH 10093-4, Solar Energy Research Institute, Golden, Colorado.

Graham, A. E. 1982. "Winds Estimated by the Voluntary Observing Fleet Compared with Instrumental Measurements at Fixed Positions." Meteorological Magazine, Vol. 111.

Hatch, W. L. 1983. Selective Guide to Climatic Data Sources. National Climatic Data Center, Asheville, North Carolina.

Hiester, T. R., and W. T. Penne11. 1981. The Meteorological Aspects of Siting Large Wind Turbines. PNL-2522, Pacific Northwest Laboratory, Richland, Washington.

Hinton, B. B., and D. P. Wylie. 1985. "A Correction for the Errors in Ship Reports of Light Winds." Journal of Atmospheric and Oceanic Technology, Vol. 2, pp. 353-356, American Meteorological Society.

Isemer, H. J., and L. Hasse. 1985. The Bunker Climate Atlas of the North Atlantic Ocean, Volume 1: Observations, Springer-Verlag, $218 \mathrm{pp}$. 
Justus, C. G., W. R. Hargraves, and A. Mikhail. 1976. "Reference Wind Speed Distributions and Height Profiles for Wind Turbine Design and Performance Evaluation Applications." ERDA ORO/5108-76/4, National Technical Information Service, Springfieid, Virginia.

Justus, C. G., W. R. Hargraves, A. Mikhai1, and D. Graber. 1978. "Methods for Estimating Wind Speed Frequency Distributions." Journal of Applied Meteorology, 17:350-353.

Kaufeld, L. 1981. "The Development of a New Beaufort Equivalent Scale." Meteorol Rundsch, 34:17-23.

National Data Buoy Center. 1986. Climatic Summaries for NDBC Data Buoys, 339 pp., National Climatic Data Center, Ashevilie, North Carolina.

Naval Oceanography Command. 1981. U.S. Navy Marine Climatic Atlas of the World, Volume IX, World-wide Means and Standard Deviations. NAVAIR 501C-65, National Climatic Data Center, Asheville, North Carolina.

Naval Oceanography and Meteorology. 1977. U.S. Navy Marine Climatic Atlas of the World, Volume II (Revised), North Pacific Ocean. NAVAIR 50-1C529, National Climatic Data Center, Asheville, North Carolina.

Naval Oceanography Command. 1985-1986. U.S. Navy Climatic Study of the Caribbean Sea and Gulf of Mexico, Volumes 1 through 4 . NAVAIR 501C-543 through -546, National Climatic Data Center, Asheville, North Carolina.

Naval Weather Service Command. 1974. U.S. Navy Marine Climatic Atlas of the World, Volume 1 (Revised), North Atlantic Ocean. NAVAIR 50-1C-528, National Climatic Data Center, Asheville, North Carolina.

NOAA. 1985. Catalog of Aeronautical Charts - and Related Publications. National Ocean Service, Riverdale, Maryland.

Pacific Northwest Laboratory. 1980-1981. Wind Energy Resource Atlases: Volumes 1-12. PNL-3195 WERA-1 through -12, Pacific Northwest Laboratory, Richland, Washington.

Pennel1, W. T. 1983. Siting Guidelines for Utility Application of Wind Turbines. RP 1520-1, Electric Power Research Institute, Palo Alto, California.

Quayle, R. G. 1974. "A Climatic Comparison of Ocean Weather Station and Transient Ship Records." Mariners Weather Log, 18:307-311.

Quayle, R. G. 1980. "Climatic Comparisons of Estimated and Measured Winds from Ships." Journal of Applied Meteorology, Vol. 19, No. 2.

Schroeder, T. A., A. M. Hori, D. L. Elliott, W. R. Barchet, and R. L. George. 1981. Wind Energy Resource Atlas: Vol. 11 - Hawai $i$ and Pacific Is lands. PNL-3195 WERA-11, Pacific Northwest Laboratory, Richland, Washington. 
Schwerdtfeger, W., Ed. 1976. "Climate of Central and South America." World Survey of Climatology, Vol. 12, Elsevier Science, 532 pp.

Van Loon, H., Ed. 1984. "Climates of the Oceans." World Survey of Climatology, Vol. 15, Elsevier Science, $716 \mathrm{pp}$.

Verploegh, G. 1967. Observation and Analysis of the Surface Wind Over the Ocean. KNMI, DeBilt, Netherlands, 62 pp.

Wegley, H. L., J. V. Ramsde11, M. M. Orgi11, and R. L. Drake. 1980. A Siting Handbook for Small Wind Energy Conversion Systems. PNL-2521 Rev. 1, Pacific Northwest Laboratory, Richland, Washington.

Wegley, H. L., D. L. Elliott, W. R. Barchet, and R. L. George. 1981. Wind Energy Resource Atlas: Vol. 12 - Puerto Rico and U.S. Virgin Islands. PNL-3195 WERA-12, Pacific Northwest Laboratory, Richland, Washington.

World Meteorological Organization. 1976. International List of Selected, Supplementary and Auxiliary Ships. WMO/OMM-No. 47, Geneva, Switzerland, $250 \mathrm{pp}$. 


\section{APPENDIX}

MONTHLY MAPS OF THE PREVAILING DIRECTIONS

OF POWER-PRODUCING WINDS 
- 


\section{APPENDIX}

\section{MONTHLY MAPS OF THE PREVAILING DIRECTIONS OF POWER-PRODUCING WINDS}

This appendix contains monthly maps of the prevailing directions of powerproducing winds for marine areas of the Caribbean and Central America region, based on an analysis of one-degree quadrangle ship data. These maps allow a user to estimate the prevailing directions of the power-producing winds and relative magnitudes of the large-scale flow patterns throughout the course of a year for a particular area of interest. These maps should be useful in combination with the island/country wind energy resource maps and tables. Local terrain effects may cause some variations locally in the prevailing directions of the power-producing winds.

The mean scalar wind speed, averaged over all directions, is denoted by the type of arrowhead and the length of the tail. A key to the arrowhead types is given along the top of each map. These maps are intended only for use in determining rélative ranges of wind speed, not exact speeds. (More specific information of the magnitude of the wind resource is included on the island/ country wind resource maps and tables.) Blank areas without arrowheads represent either areas with insufficient ship data, such as the Great Bahama Bank, or land areas. Although the data only represent that portion of a one-degree grid cell that is over water, the tip of the arrowhead is always plotted at the center of the grid cell. Directions may be quite variable over areas where two or more different flow patterns are prevalent, such as transition areas between easterlies and westerlies, or over areas with light winds. In a few cells with limited or questionable data, the directions may be in error and not representative. 


\section{JANUARY \\ PREVAILING DIRECTION OF POWER PRODUCING WINDS}

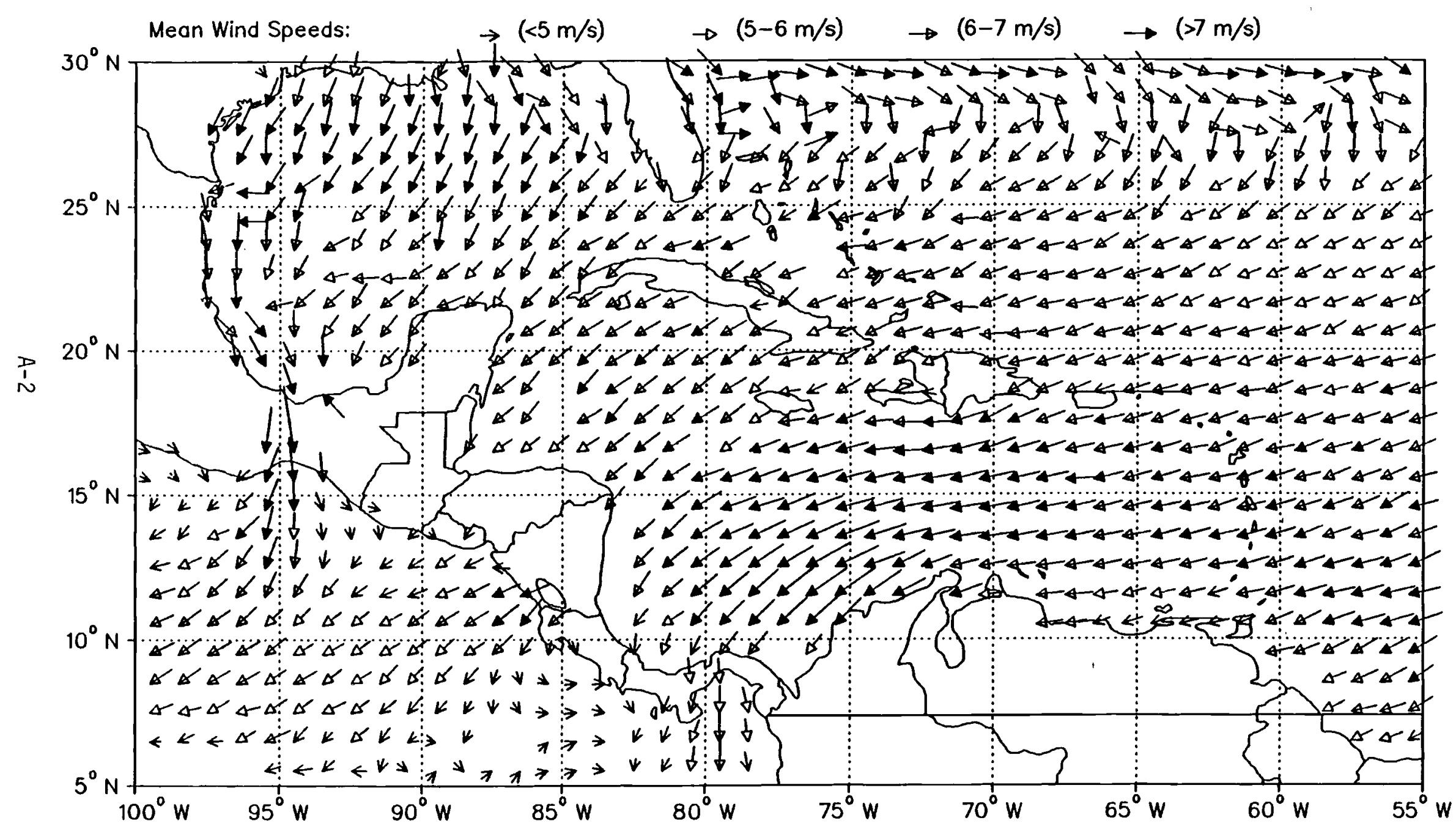




\section{FEBRUARY}

\section{PREVAILING DIRECTION OF POWER PRODUCING WINDS}

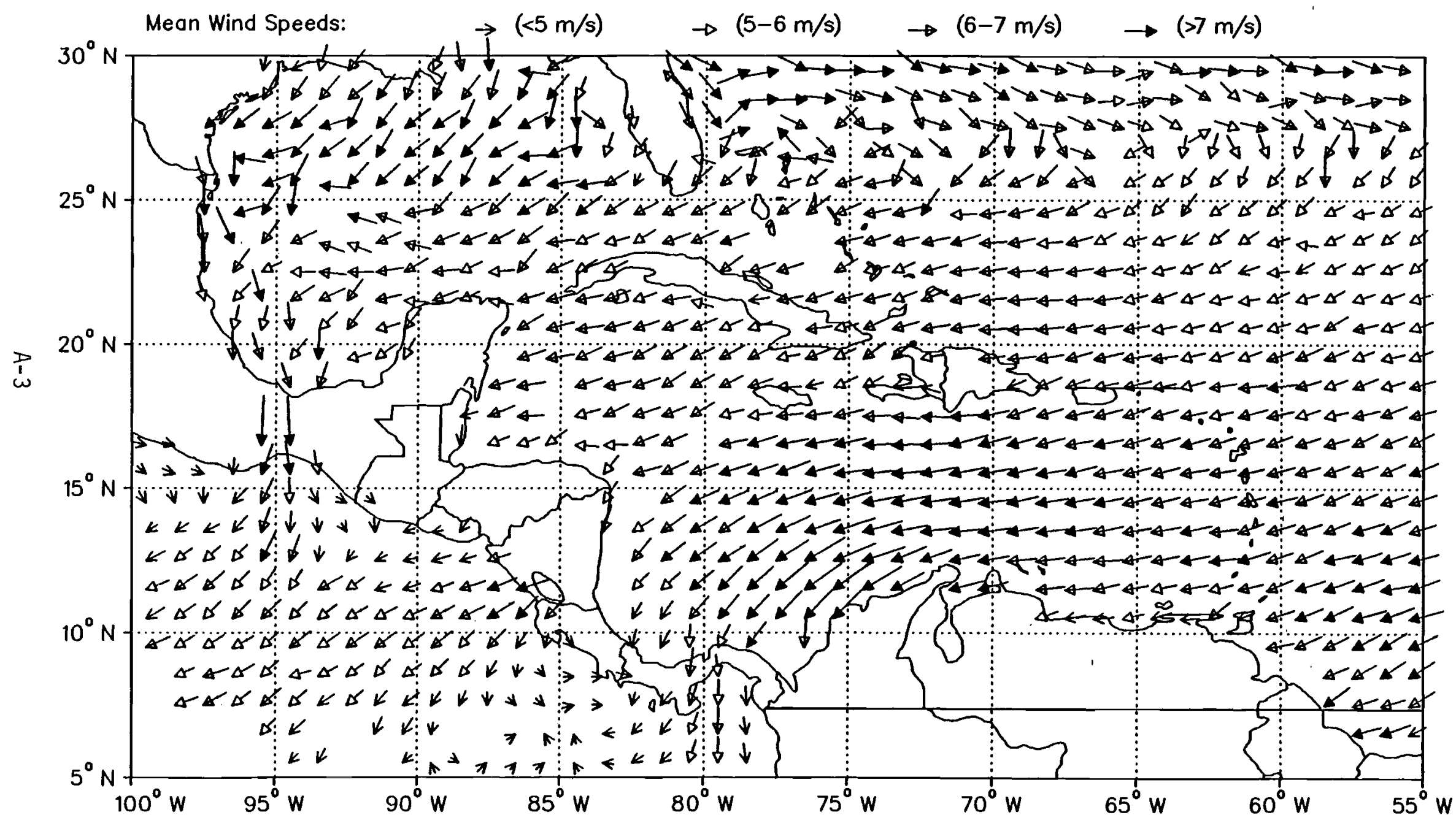




\section{MARCH}

\section{PREVAILING DIRECTION OF POWER PRODUCING WINDS}

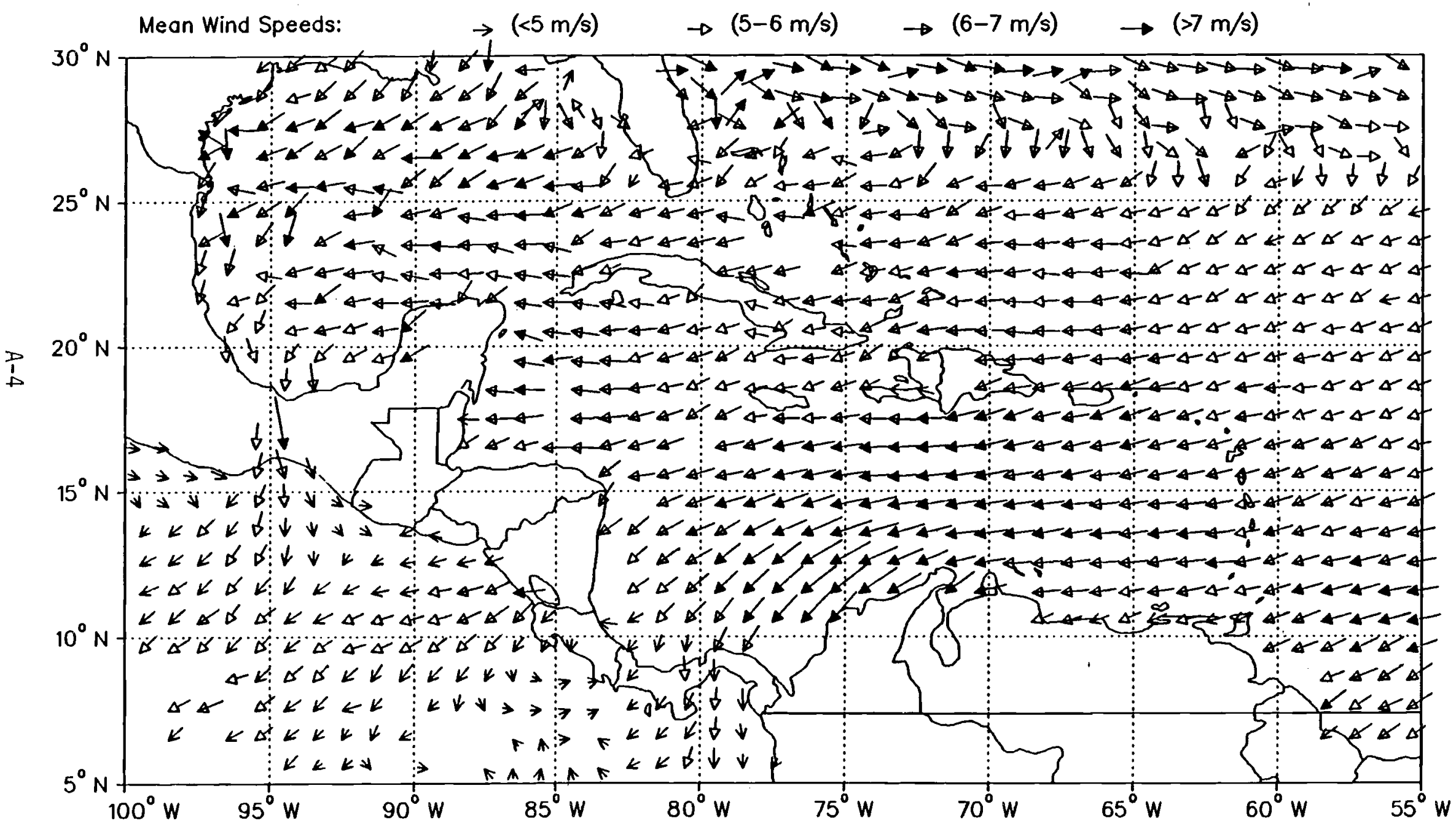




\section{APRIL}

\section{PREVAILING DIRECTION OF POWER PRODUCING WINDS}

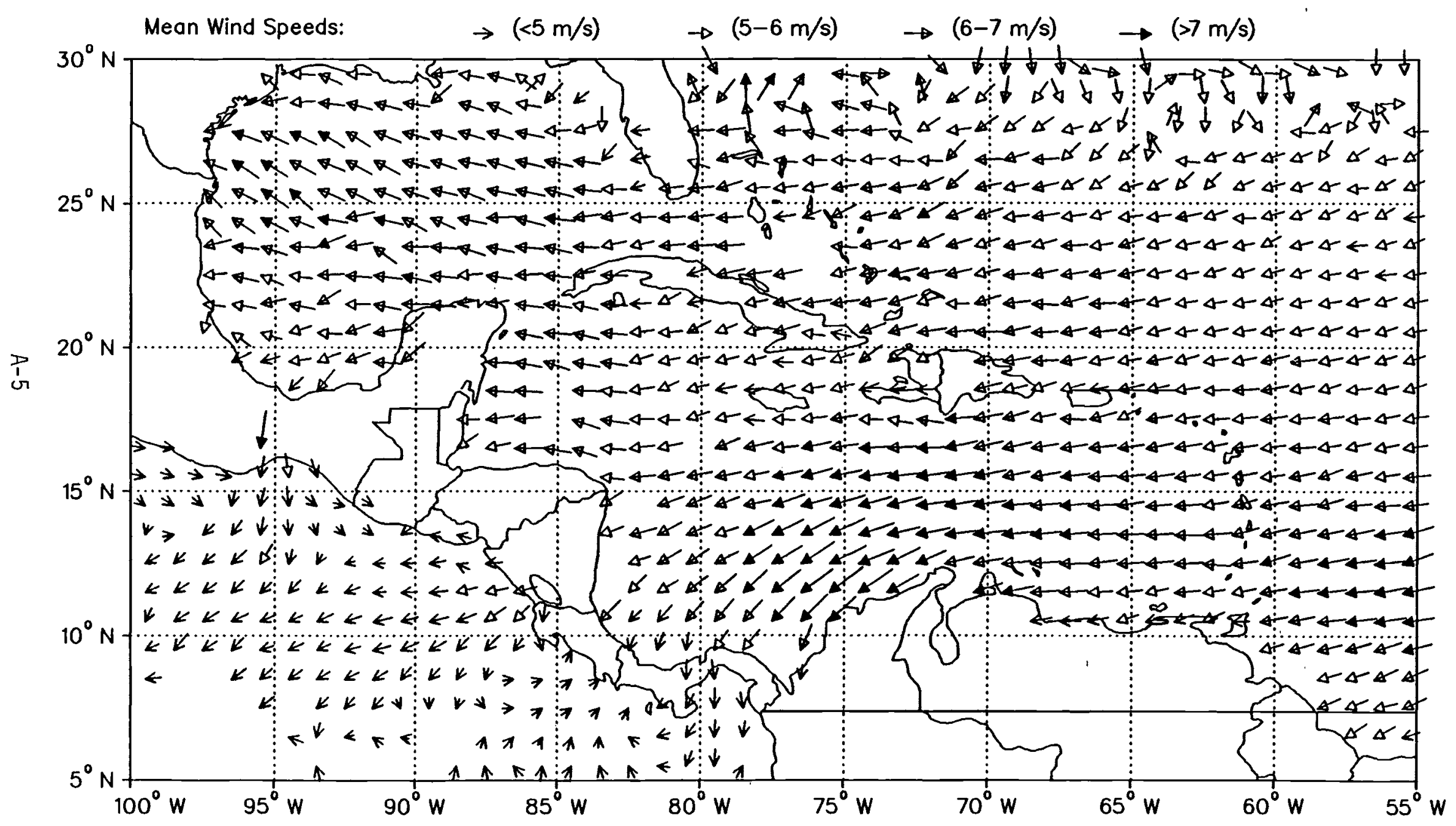




\section{MAY}

\section{PREVAILING DIRECTION OF POWER PRODUCING WINDS}

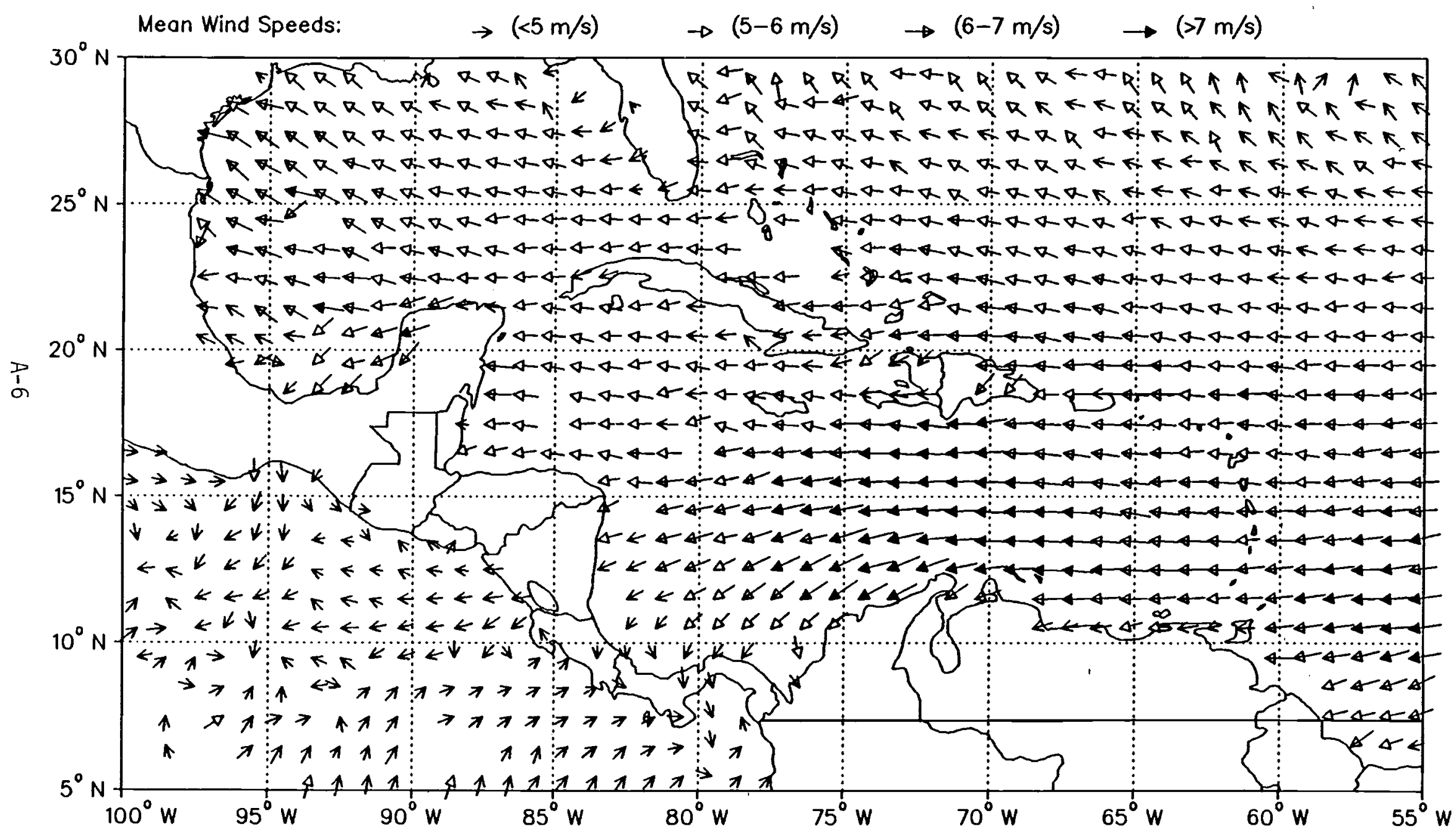


JUNE

PREVAILING DIRECTION OF POWER PRODUCING WINDS

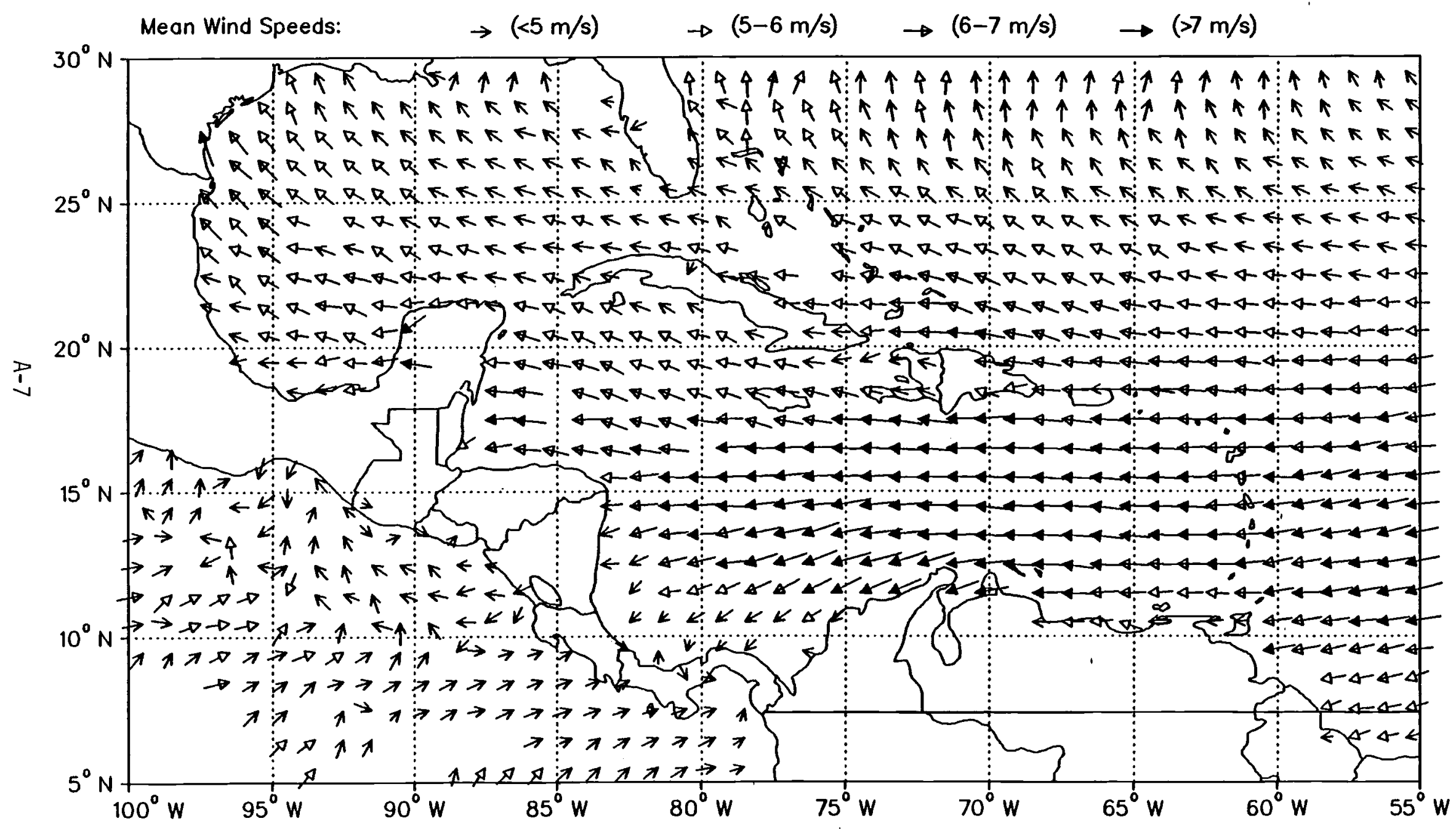




\section{JULY}

\section{PREVAILING DIRECTION OF POWER PRODUCING WINDS}

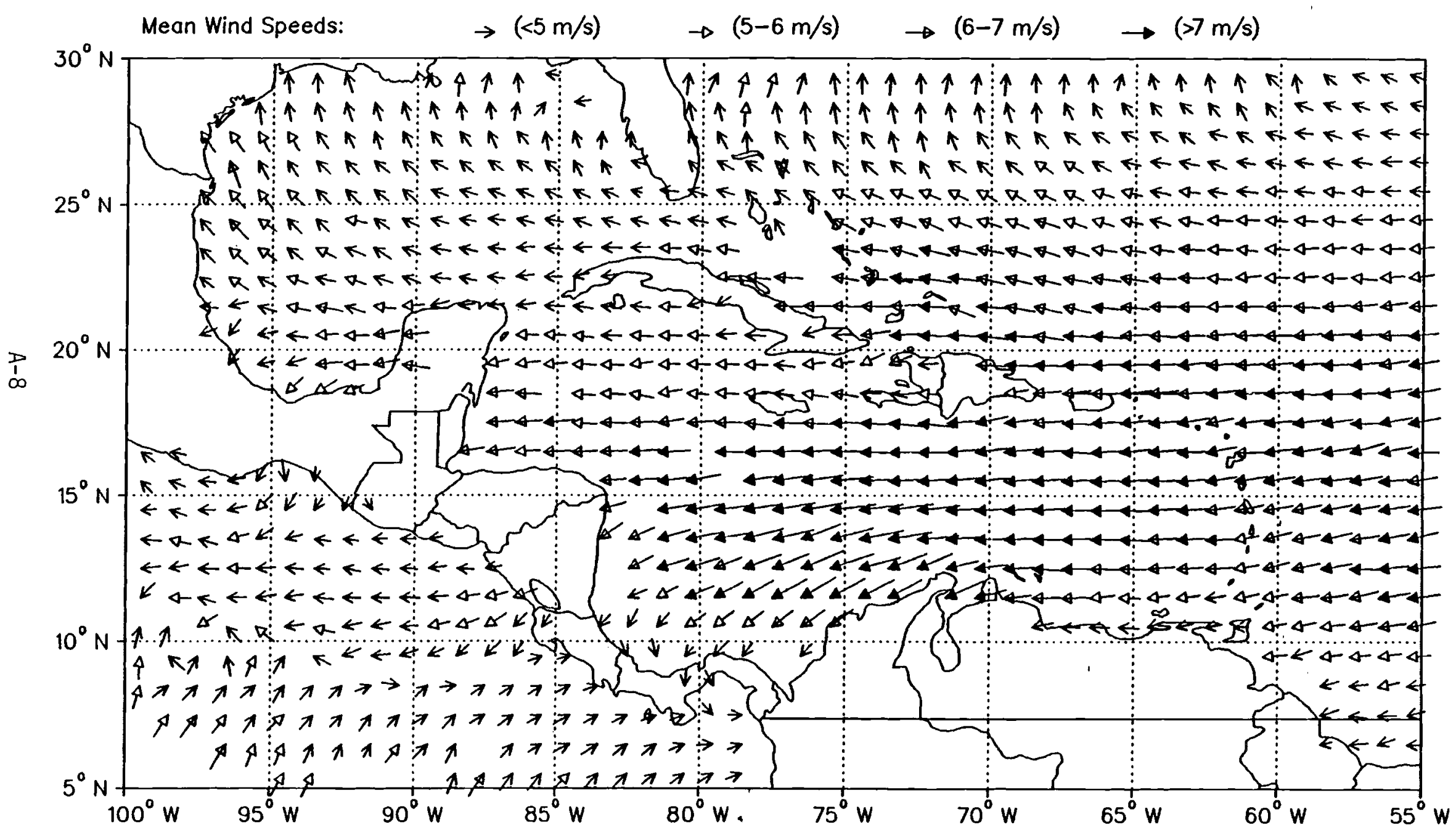




\section{AUGUST \\ PREVAILING DIRECTION OF POWER PRODUCING WINDS}

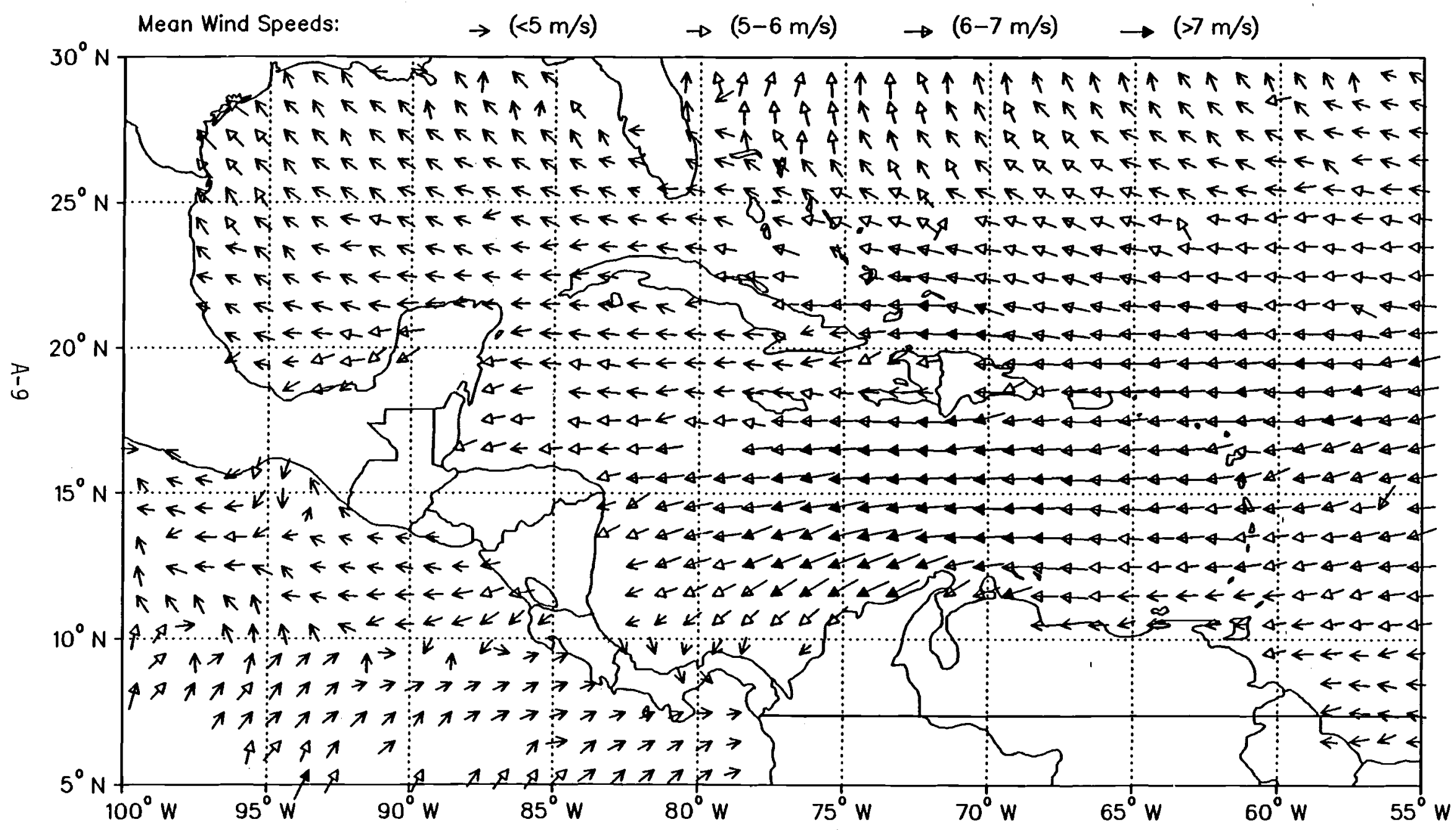




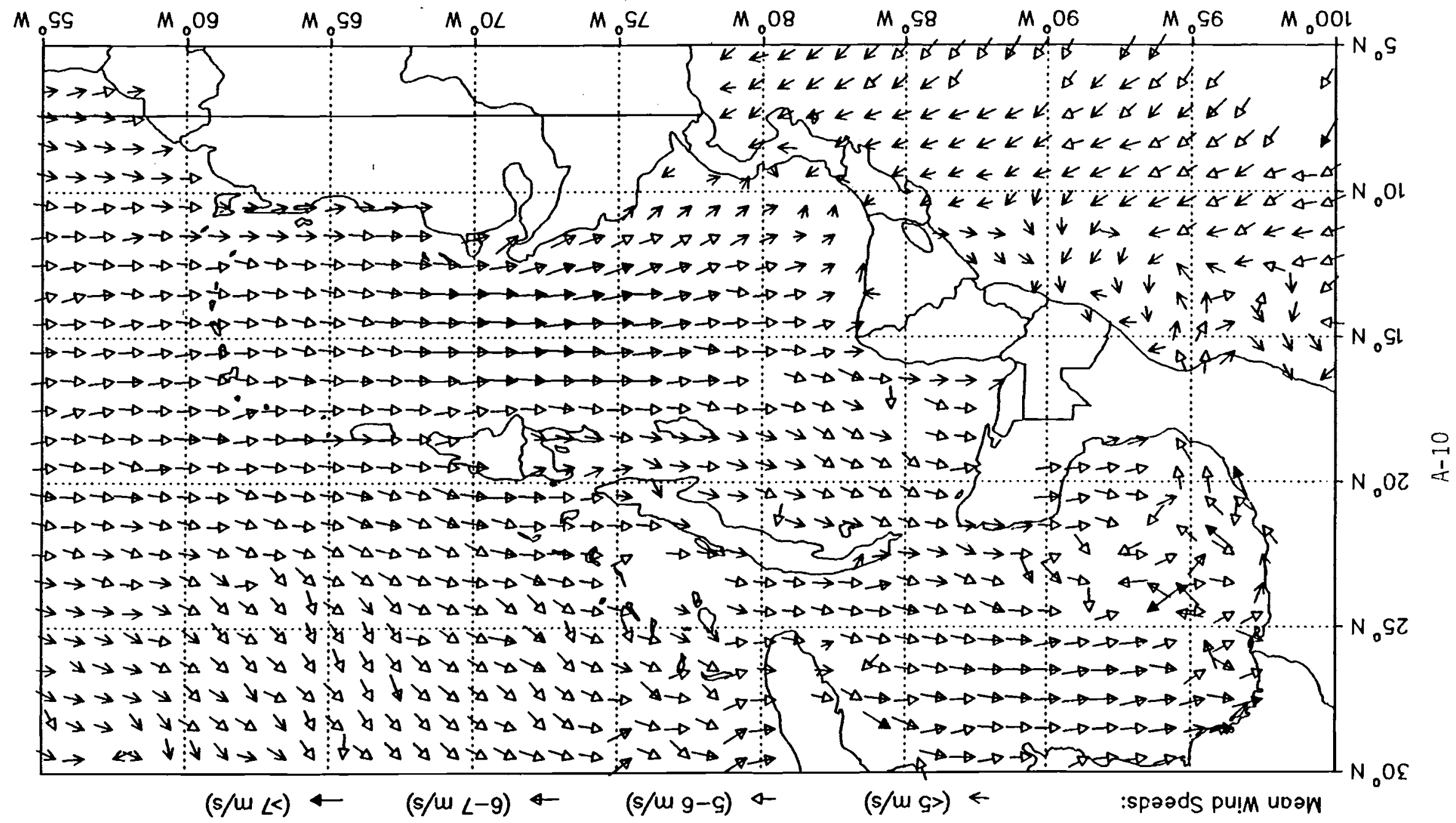

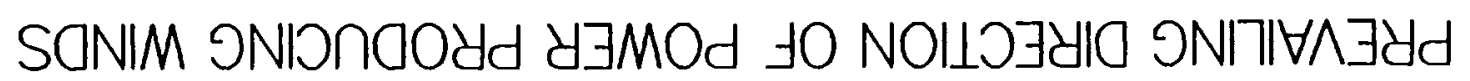

¿ $\exists \boxminus N \exists \perp d \exists S$ 


\section{OCTOBER}

\section{PREVAILING DIRECTION OF POWER PRODUCING WINDS}

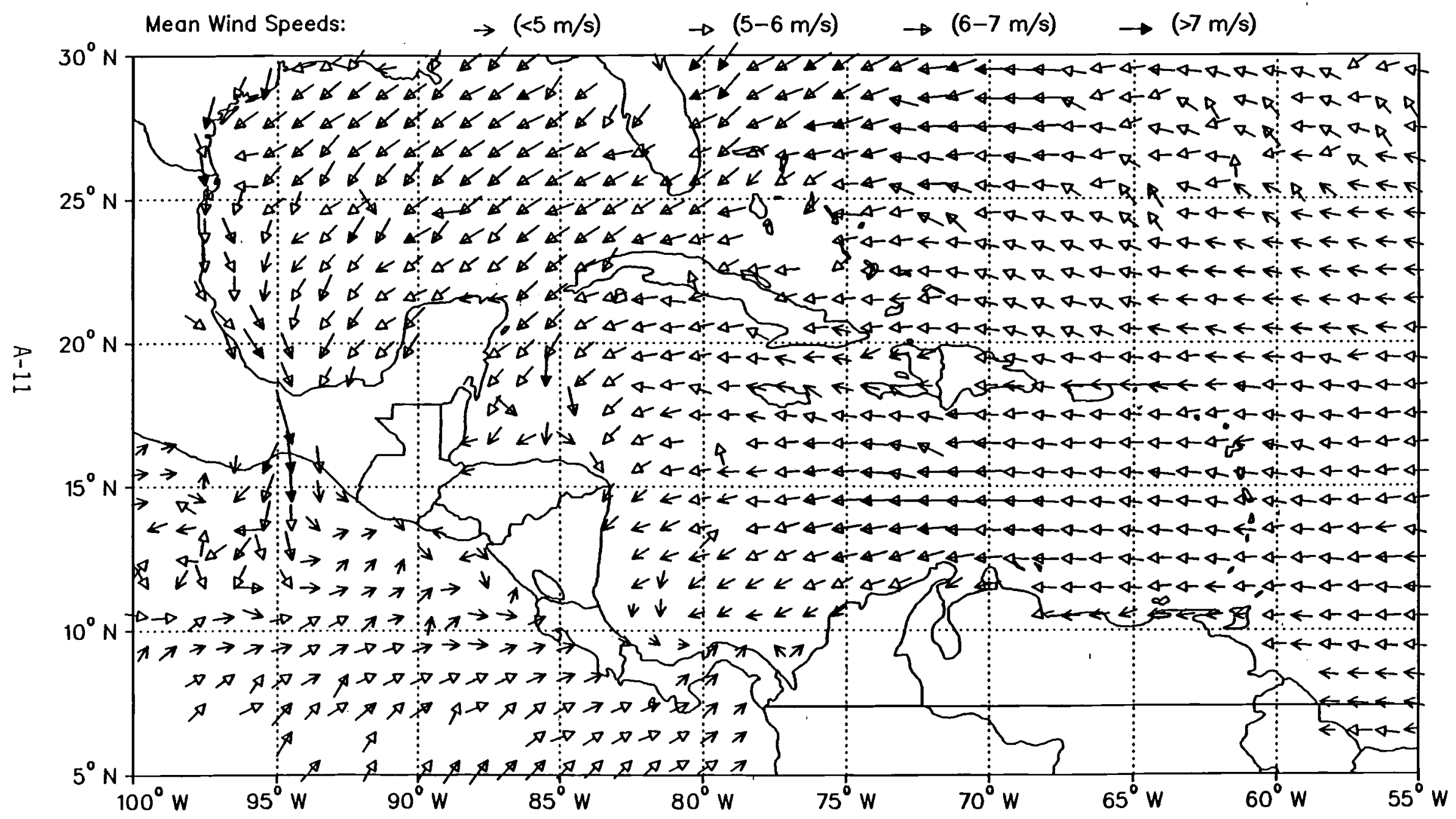




\section{PREVAILING DIRECTION OF POWER PRODUCING WINDS}

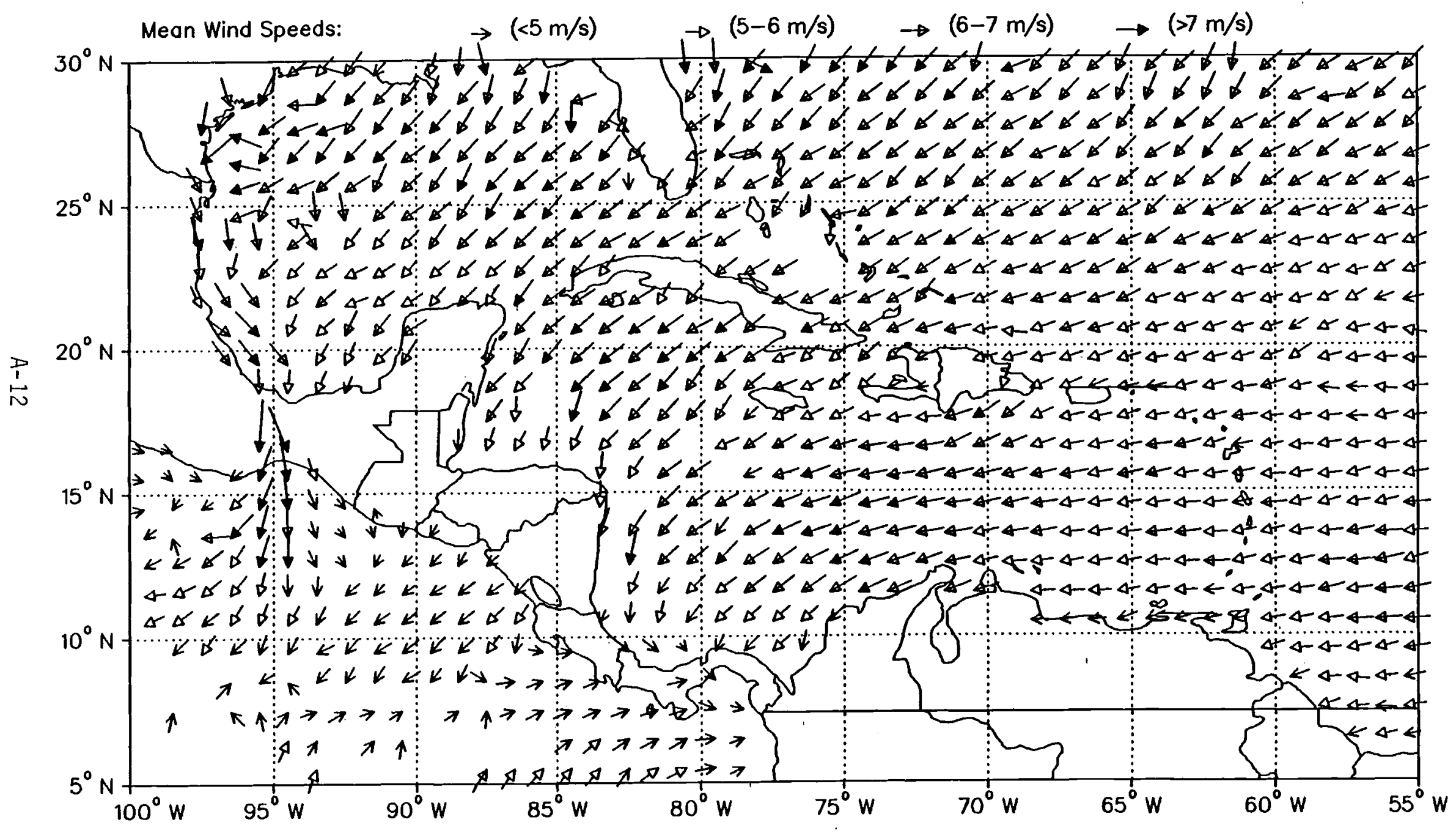




\section{DECEMBER}

\section{PREVAILING DIRECTION OF POWER PRODUCING WINDS}

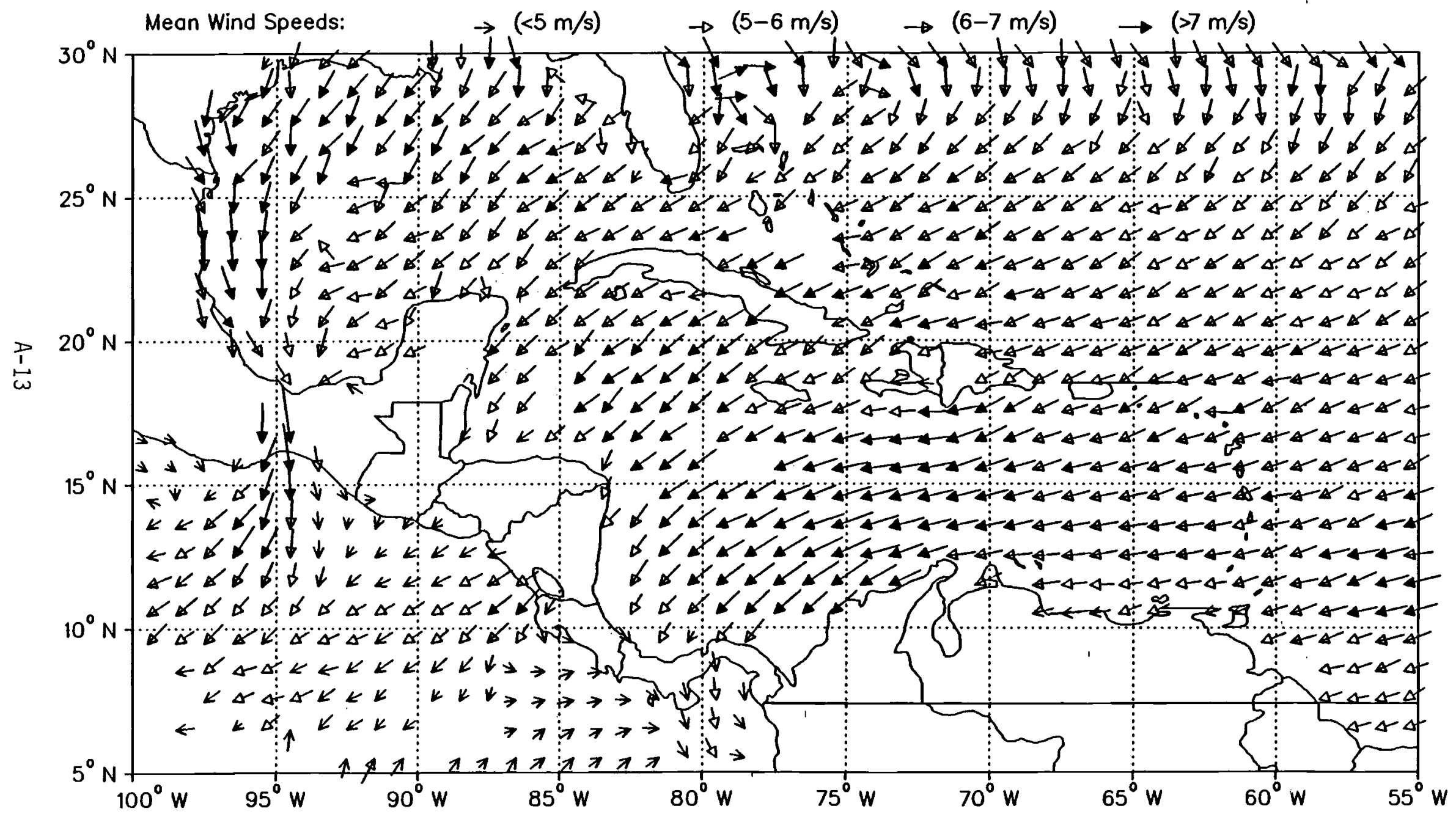


PNL-

UC -60

\section{DISTRIBUTION}

No. of

Copies

\section{OFFSITE}

Carl Aspliden

Battelle Memorial Institute Washington Office

2030 M Street, NW

Washington, DC 20036

\section{J. Cadogan}

U.S. Department of Energy

Wind/Ocean Technologies Division

1000 Independence Avenue

Forrestal Building, Room $5 \mathrm{HO} 048$

Washington, DC 20585

\section{F. Ancona}

U.S. Department of Energy

Wind/Ocean Technologies Division

1000 Independence Avenue

Forrestal Building, Room $5 \mathrm{HO} 48$

Washington, DC 20585

G. P. Tennyson

U.S. Department of Energy

Albuquerque Operations Office

P.0. Box 5400

Albuquerque, NM 87110

40 Tom Gray

American Wind Energy Association

1017 King St. \#A

Alexandria, VA 22314-2922

2 DOE Technical Information Center
No. of

Copies

ONSITE

DOE Richland Operations Office

J. J. Sutey/D. R. Segna

37 Pacific Northwest Laboratory

J. C. Barnard

J. W. Buck

J. R. Connell

D. W. Dragnich

C. E. Elderkin

D. L. Elliott (5)

J. M. Hales

P. C. Hays

M. E. Hinchee

A. H. Miller

V. R. Morris

E. L. Owczarski

D. C. Powell

J. A. Stottlemyre

T. K. Thompson

L. L. Wende 11 (10)

R. E. Wildung

Publishing Coordination (2)

Technical Information (5) 
$!$ 